\title{
WestVirginiaUniversity
}

THE RESEARCH REPOSITORY @ WVU

Graduate Theses, Dissertations, and Problem Reports

2013

\section{American grail: Contemporary federal budget reform}

Velda Frisco

West Virginia University

Follow this and additional works at: https://researchrepository.wvu.edu/etd

\section{Recommended Citation}

Frisco, Velda, "American grail: Contemporary federal budget reform" (2013). Graduate Theses,

Dissertations, and Problem Reports. 380.

https://researchrepository.wvu.edu/etd/380

This Dissertation is protected by copyright and/or related rights. It has been brought to you by the The Research Repository @ WVU with permission from the rights-holder(s). You are free to use this Dissertation in any way that is permitted by the copyright and related rights legislation that applies to your use. For other uses you must obtain permission from the rights-holder(s) directly, unless additional rights are indicated by a Creative Commons license in the record and/ or on the work itself. This Dissertation has been accepted for inclusion in WVU Graduate Theses, Dissertations, and Problem Reports collection by an authorized administrator of The Research Repository @ WVU.

For more information, please contact researchrepository@mail.wvu.edu. 


\title{
AMERICAN GRAIL: CONTEMPORARY FEDERAL BUDGET REFORM
}

\author{
Velda Frisco \\ Dissertation submitted \\ to the Eberly College of Arts and Sciences \\ at West Virginia University \\ in partial fulfillment of the requirements for the degree of
Doctor of Philosophy
in
Political Science \\ Jeffrey S. Worsham, Ph.D., Chairperson \\ Neil Berch, Ph.D. \\ John C. Kilwein, Ph.D. \\ Jason A. MacDonald, Ph.D. \\ Odd J. Stalebrink, Ph.D. \\ Department of Political Science
}

Morgantown, West Virginia

2013

Keywords: Federal Budget Reform, Program Assessment Rating Tool, PART Copyright 2013 Velda Frisco 


\section{Abstract \\ American Grail: \\ Contemporary Federal Budget Reform}

Velda Frisco

Federal budget reforms initiated by the executive branch of government have been unsustainable. A commonality of these failed reforms is that they lack the support of Congress. The objective of this research is to determine whether the Program Assessment Rating Tool (PART), the most recent executive-initiated budget reform, was supported by Congress. The scope of this research includes an exploration of historic budget reforms, initiated from 1921 through 2008, to provide insight into previous reform sustainability.

Budget reforms provide context from which to view the power struggle between the executive and legislative branches of government; the tension of separate institutions sharing power. This research also offers insight into the extent that the U.S. separation of powers structure interferes with the implementation of government-wide performance measurement systems at the federal level.

Using data obtained from congressional committee hearings this research finds little congressional interest in PART; legislators were primarily indifferent to this executive tool. Generalizing congressional PART sentiment, results indicate that legislators with more business experience are more likely to be supportive of budget reforms making them important stakeholders to include in the next effort at reforming the budget process. Legislators with greater seniority and those who receive more campaign contributions from political action committee are more likely to resist reform.

The research demonstrates that reforms that are the product of cooperation between both executive and legislative branches are more likely to be sustained; legislating budget reforms is key to sustained executive-initiated reforms. In addition, analyses of historic budget reforms show that the legislature has been the driver of budget reforms, not the executive. 
Table of Contents

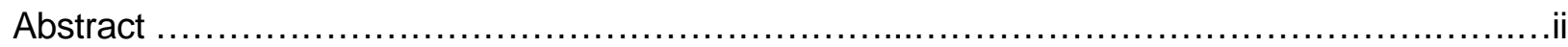

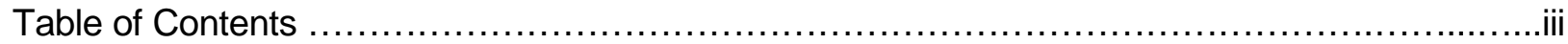

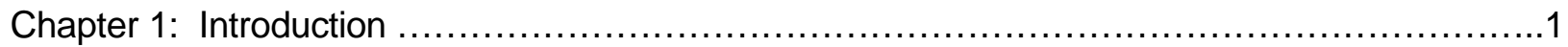

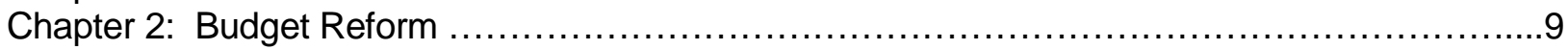

Chapter 3: Congressional Use of PART: Legislative Sentiments $\ldots \ldots \ldots \ldots \ldots \ldots \ldots \ldots \ldots \ldots \ldots \ldots \ldots$

Chapter 4: Congressional Use of PART: Legislative Characteristics ......................... 60

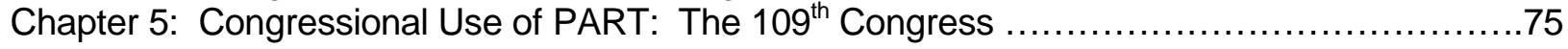

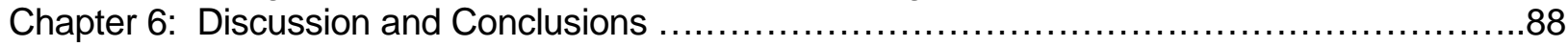

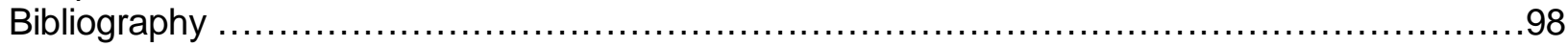




\section{Chapter 1 \\ Introduction}

"All political issues, sooner or later, become budgetary issues." Donald F. Kettl (2003, p. 1)

Federal budgeting is a mess. The process of federal budgeting and appropriations has not aided Congress in its efforts to stay within its means. The U.S. has had a budget surplus in only 28 (12\%) of the past 224 years. Budget impasses are more frequent: U.S. debt is at a record high. The debt limit, which allows us to continue paying our debts, has been raised 79 times since 1960; 49 times under Republican presidents and 30 times under Democratic presidents (U.S. Department of the Treasury, 2012). Despite attempts at reform, the task of deciding which programs and activities get funded and at what level has not gotten any easier. New government programs overlay old programs, with overlapping agency authority, in a tangled web of complexity. The growth of executive and legislative staff, the addition of the Office of Management and Budget (OMB) and the Government Accountability Office (GAO), and the use of modern computing power has improved our capacity but has done little to improve our budgeting prospects. The discretionary part of the budget is an ever-shrinking pot, as $64 \%$ of the budget remains untouchable with obligations such as Medicare, Medicaid, and Social Security (Austin, 2013). However, the legislature, the president, and their agents spend an exceedingly high level of effort in compiling the annual budget, because control of the budget means control of the national agenda.

Budgets indicate priorities, manifest preferences, influence the economy, demonstrate how public money is spent, and provides a record of the power of individual and group influence (Rubin, 2006). It is no surprise, then, that the evolution of federal budgeting in the U.S. is fraught with conflict, efforts of reform, and unintended consequences. The U.S. Constitution (Article I, Section 8) places the responsibility for the budget in the hands of the legislature with the ability to tax, borrow, and spend; no direct fiscal role was granted to the executive other than the ability to veto legislation.

In the past, each federal agency requested funding directly from the appropriations committees, in a bottom-up flow of information. Congress decided how much it wanted to spend, passed a bill doing so, and sent it for signature to the President. With time, this structure proved unmanageable for a growing nation; parochial needs were met, but no central focus existed from which an over-arching perspective could be maintained. World War I greatly increased U.S. expenditures from $\$ 700$ million a year, prior to the war, to $\$ 18.5$ billion in 1919 (Schick, 2000, p. 14). Meanwhile, the states were successfully adopting formal budgeting systems whereby budgets were submitted by the governor. These successes focused attention on the federal budgeting process (Anderson, Davis, \& Gullo, 2003). As a result, the Budget and 
Accounting Act of 1921 (BAA; PL 67-13) brought the President into the process to formulate the budget, enabling the development of a centralized spending plan. It also formalized the president's agenda into the budget process. Thus, annual budgeting commenced with the President conveying his policy goals to the agencies in a top-down flow. The BAA also created the Bureau of the Budget (BOB) to support the president's budget efforts and the GAO to audit the executive. The power of the purse that rests with Congress was diluted to incorporate a more national perspective. As a consequence, the rivalry that naturally follows our structure of balance of powers was intensified for control of spending and the national agenda. Kettl (2003) referred to the BAA as one of the most significant changes to the balance of power in the history of the U.S.

As a consequence of the BAA, the balance of power is sorted out with each federal budget. Successive presidents have continued to flesh out their role as budget centralizer. Subsequent reforms were initiated by both the executive and legislative branches to enhance the budgeting process by improving economy and efficiency; simplifying the budget; controlling operations, information, agency goals; and reducing the deficit. In particular, reforms initiated by the executive branch have largely been unsustainable. A commonality of these failed reforms is that they lack the support of Congress.

\section{Research Goals}

The objective of this research is to determine whether the Program Assessment Rating Tool (PART), the most recent executive-initiated budget reform, was supported by Congress. The last successful budget reform, the Government Performance and Results Act (GPRA), was a legislative branch initiative. As noted by Joyce (2011a).

While it has become fashionable to view these reforms as "failures," this seems an overly harsh postmortem. Evaluations frequently have not been conducted at enough distance (in terms of time or perspective) from the "reform" to permit a real evaluation of effects ... Viewed through the lens of history, these reforms can be seen as part of a general upward trend in attention to performance concerns throughout the entire twentieth century-each reform taught us things, developed capacity, and made it more likely that future reforms would be implemented (p. 358).

Thus, the scope of this research includes an exploration of historic budget reforms, initiated from 1921 through 2008, to provide insight into reform sustainability. Contemporary budgeting literature also focuses on executive-initiated reforms giving limited consideration for budget reform initiated by Congress. Chapter 2 contributes to the literature by reclaiming legislative-initiated reform efforts, broadening the scope of reform by exploring past legislative reforms to provide insight into what made previous reforms sustainable. 
Bringing the topic into contemporary budgeting, Chapters 3 through 5 examine congressional sentiment about PART. Little research has been done on this topic (Moynihan, 2006; Gruber, 2003; U.S. GAO, 2005). In order for a reform to be sustained it must provide value to those who use it. Federal agencies were required to use PART to justify their budget requests. However, an important question for the Bush Administration was whether Congress used PART. Using data from congressional committee hearings this research demonstrates limited congressional interest in PART; the characteristics and commonalities of legislators supportive of PART; and provides insight into the lack of sustainability of this executive-initiated reform.

\section{Background}

Over the past 60 years, efforts to implement performance budgeting systems in the United States have been widespread. However, these efforts have either failed to be sustained across subsequent administrations or have been ignored. Moynihan (2006) suggested that implementation is the cause due to the difficulty of making policy work in an environment characterized by multiple actors with different motivations. In a separation of powers structure this challenge is exacerbated when the executive branch seeks to implement government-wide performance measurement systems. As noted by Schick (2000) this separation gives rise to a contest over the control over the power of the purse in which each branch develops its own budget process, each with its own budget staff and operating rules, for purposes of gaining an advantage in the budget process - the friction of institutions.

Rubin (2006) summarized the politics of the budgetary process as characterized by: incremental bargaining negotiated between routine actors; determined by interest groups where the rich and powerful dominate; reformist in its drive for neutral rationality; involving an inter-branch struggle for power; and the battlefield where policy debates are fought over such issues as spending levels, the size of government, or tax reductions. This chapter explores both legislative-initiated budget reforms along the more often cited executive reforms assessing which institution benefited from the reform; how the reform was framed; and the benefits the reform had on federal budgeting.

Post Wildavsky’s incrementalism, neutral rationality has become the dominant budgeting theme. Many budgeting and finance academics are trained in the public administration tradition of neutral competence; advocating public administrators, the audience for which they write, to act independent of politics for the greater good where no person or entity has more influence than another over the actions and activity of government. Such true and admirable goals have great merit. It is also naïve, because it provides little support for those who budget. Budgets are not created in a political vacuum; they are living 
documents whose content directly impacts the lives of others. Wildavsky (2004) described budgeting as the "lifeblood of government, the medium through which flowed the essential life support systems of public policy” (p. xxvii). Budgets demonstrate where our priorities lay as a society; it leaves a record about what we value.

Wildavsky (2004) observed, "the budget process embraces a dynamic imbalance of constituency politics, states' rights, ideological agendas, the whole and the parts, and institutional prerogatives, as well as administrative values (e.g., efficiency, effectiveness, economy, productivity, planning) and substantive interests (e.g., environment, poverty, industry, trade, foreign aid, defense)” (p. 192). Budgeting is about who wins and who loses; it's about making value judgments about what kind of society we will have and what groups are advantaged. We are society that instructs us that we are all winners, but the reality of limited resources teaches us otherwise. Gilmour (1990) opined that no one gets hurt directly by the budget deficit; the costs are too widely distributed across people and time. It is no wonder, then, that the hue and cry over the national debt is raised when politically expedient, such as when the credit ceiling must be increased or during election cycles to rally the conservative base.

Kettl (1992) considered the budget as "a prism that breaks apart, for careful study, the critical issues of American politics” (p. 14). In general, Democrats (liberals) prefer an increase in revenue to reduce the deficit and an increase in taxes on the rich to pay for services for the poor. They support more regulation of business, less defense spending, and government intervention in social problems. Republicans (conservatives) prefer to cut taxes and reduce spending, thereby shrinking the size of government. Their preferences generally include greater defense spending, reduced social services, and less regulation of business. Democrats can be loosely classified as Keynesian in their economic approach to government; Republicans as laissez-faire; Franklin Roosevelt vs. Ronald Reagan, for example.

As noted by Gilmour (1990), broader policy changes are easier to make because the cost are incurred indirectly, as opposed to the cuts made to particular programs where costs are incurred by particular legislators and their constituents. Reciprocity works when distributing benefits not costs. This helps to explain the current use of sequestration, where the costs are borne across the board. Responsibility to hit the targeted reduction falls to the agencies who best know where to make the surgically precise cuts to blunt the bloodletting; it also enables Congress to avoid blame for the costs and to claim credit for the drop in the overall debt. 
How do we explain the contrary actions of our legislators who consistently fail to deliver a budget on time year after year? The weakness of the party system necessitates the formation of coalitions for reconciliation. This makes the budgeting process even longer. How do we explain a process that has expanded such that it now begins a year and a half in advance, but still avoids closure? The President's forecast in his February budget, is based on numbers ran in December of the previous year for a budget that runs 21 months into the future. Even our most sophisticated computer models cannot predict the economic variability over that period of time. It also provides a disincentive for Congress to act quickly on the President's budget.

Complicating the budget process is the process changes themselves and previous and longstanding obligations. An example of these changes is the resolution/reconciliation process. In the budgeting process the appropriations committee produces 12 bills, one from each subcommittee. These bills are considered in serial fashion, but without a subcommittee responsible for the total. This fragmentation kept ideological battles from overwhelming the process; made the budget easier to pass; made it easier for legislators to claim credit; and helped legislators avoid personal responsibility (Gilmour, 1990). At the same time it enabled Congress to ignore deficits. With the changes made to the budgeting process by the Congressional Budgeting and Impoundment Control Act of 1974, a new layer of negotiation was added. Factions now have less power to obstruct what they oppose.

The budget resolution allowed Congress to set fiscal policy through the use of reconciliation. The budget resolution was used every year from its inception through 1998 (Joyce, 2011b). Since then it has been treated as an option. Intended as a fiscal control, it was used with reconciliation procedures to pass the 2001 and 2003 tax cuts, and the expansion of Medicare (Joyce, 2011b). According to Gilmour (1990),

Reconciliation, a revolutionary tool, enables congressional majorities to overcome barriers to swift and comprehensive action, dramatically reduces the long-standing capacity of committees to block legislative desires of majorities, facilitates intercommittee negotiations, and perhaps more important, increases the probability that the results of negotiations will be implemented (p. 5).

Gilmour (1990) observed that the reconciliation process allows shifting alliances outside the committees to push budget preferences and agendas to the committees; a reverse of a legislative process where the committees normally lead. A primary example is the Reagan budget of 1981, where House Republicans and conservative Democrats enacted the President's budget without regard to opposition in the committees or majority party preferences. Using this process, bipartisan representatives of both the 
House and Senate, in cooperation with the Reagan Administration, negotiated a \$30 billion deficit reduction agreement after the Black Monday scare of October 19, 1987. The committees then drafted legislation based on the negotiations. Wildavsky (2004) stated that "reconciliation represented a permanent institutional attack on the budgetary base, opening up to negotiation the boundaries of past political contracts” (p. 91). As a result, Congress began relying more on CBO’s budget or the House or Senate resolutions than the President's budget. By manipulating the baselines Congress could appear to fund programs and reduce the deficit (Wildavsky, 2004).

Legal requirements escalate the role of budgeting: agencies and programs must be funded annually (Kettl, 1992). In addition, funds must be allocated to certain types of previously made obligations. Kettl (1992) outlined the budgeting hierarchy: interest on the debt that must be paid; entitlement programs, which are politically untouchable; defense; and everything else. Each has a different type of politics. Interest on the debt and entitlement programs comprise the mandatory part of the budget that now composes $64 \%$ of the budget. Defense and everything else comprises the remaining $36 \%$. Kettl (1992) pointed out that by the 1980s all the easy cuts to the budget were already made.

Wessel (2012) observed that “in 2009, for the first time in the nation's history, every dollar of revenues had been committed before Congress walked in the door” (p. 21). Entitlements have been taken off budget because both the fiscal and policy issues that underlay these programs have become too contentious. Wildavsky (2004) quipped, “entitlement means not having to say you're sorry because the money has run out” (p. 132). Altering any of these programs will hurt some voting, mobilized constituency. The political costs are so high that it simply is not worth the risk. The legislature and the President are unable to pass a budget on time when only $36 \%$ of the budget is under evaluation; adding mandated programs would likely bring down a process that is already challenged. Although legislators frequently bemoan that entitlements are uncontrollable they do change through indexing, changes to eligibility, and taxation (Wildavsky, 2004). Congress can legislate changes, but passing such legislation would be more difficult than reducing appropriations. During the Nixon Administration, the President and Congress decided to index social security. The result was automatic increases in program expenditures and the indexing of other programs. Kettl (1992) made the point that Social Security is viewed as a right; Congress cannot claim credit for securing this right, but they can lose credit through making any effort to change social security. Likewise, Medicare is untouchable. Kettl (1992) quoted Senator Bob Dole (R, Kansas), “Somebody mentions the word 'medicare,' it is like crying 'fire' in a crowded theater" (p 56). 
A strong economy reduces the deficit and a weak one increases the deficit. Budgeting is easier when the assumptions used predict economic growth. Determining which assumptions to use in economic forecasts is another source of conflict. Because the budget is so large even small margins of error translate into millions of dollars. The Reagan Administration was famous for their overly optimistic forecasts that consistently predicted a balanced budget; when, in reality, they were escalating the deficit. When Congress caught on, they began proclaiming the President's budget dead on arrival.

The failure to balance the budget, growing debt, and the artificial crises of the debt ceiling has further complicated the process. Congress has abdicated responsibility for federal budgeting by legislating sequester, where all budgets are reduced by the same set percentage. But again, they really are not. Under the guise of national security or mandatory need, certain programs are exempt from sequester. In the federal agencies, sequester is a burden unevenly experienced, dependent on how much money has been socked away over the year or the ability to move funds (from travel to payroll, for example). Sequester has been the budgetary bogeyman since Nixon, yet we are living it, and from last reports it is working. The budget deficit has dropped enough that even Wall Street is no longer worried about the federal debt.

It is difficult to discuss politics in budgeting. How do we identify it? How do we measure it? In this and the follow chapters budgeting politics is explored through budget reform; through the tensions of institutions, the identity of ideology, the label of party, and the money of those that fund candidates.

The antithesis of reform is manifest in the continued incrementalism that drives federal budgeting. Lindblom (1959) explained that policy made incrementally helps to avoid untended consequences; small problems made as a result of new policy are easier and quicker to resolve. However, incrementalism does not look for optimal solutions-it satisfices (Simon, 1945). Incrementalism discourages the formulation of alternatives. Neither does it incorporate performance measurement, which continues to be advocated as a tool for better public management and for improved public budgeting. Unlike incrementalism, which has shown to be compatible with the politics of budgeting, the use of performance measures and the accompanying drive for transparency makes the budgeting process less politically murky. Reciprocity and ear-marking are more exposed to scrutiny.

Jones and McCaffery (2002) observed, "In the budget process, there is an intersection where the tools of professional articulation meet the needs of political representation” (p. 466). In a democracy such as the U.S., these needs have primacy over many other worthwhile goals such as efficiency and effectiveness. As stated by Bourdeaux and Chikoto (2008), “A dilemma in the design of democratic 
institutions is that the institutional arrangements that emphasize one set of objectives may undermine others” (p. 253). As representatives of geographically based constituency, legislators are focused on local concerns and priorities as opposed to the nationally elected executive whose focus is broader.

From a comparative perspective the American-style public management movement shared the basic characteristics of the Westminster reforms, including a reliance on market forces (e.g., competition) to discipline public managers and the application of private sector management frameworks (decentralized decision-making authority and private sector management tools). However, critical differences existed in the scope and depth of the reforms (Kettl, 2000). Compared to the Westminsterstyle reforms, the American reforms were implemented with fewer fundamental changes to institutional structures and processes, but more sweeping changes to the bureaucracy. Perhaps the most fundamental challenge to the American model, in this regard, stem from the separation of power system, which complicates agreement on program and agency objectives. Joyce (1993) noted that performance measurement works best nationally for parliamentary forms of government, such as Great Britain and New Zealand, where power is concentrated in one branch of government making agreement on agency objectives less complicated than in the U.S.

As stated previously, the following chapter explores previous budget reform efforts providing insight into what made previous reforms sustainable. It will assess which institution initiated and benefited from the reform; how the reform was framed; and the benefits the reform had on federal budgeting. 


\section{Chapter 2 \\ Budget Reform}

"Political institutions affect the distribution of resources, which in turn affects the power of political actors, and thereby affects political institutions." James G. March and Johan P. Olsen (1984, p. 740)

Contemporary budgeting reform literature primarily focuses on executive-initiated reforms (Norcross \& McKenzie, 2006; Olsen \& Levy, 2004; Singer, 2005; Gilmour \& Lewis, 2006a, 2006b; Moynihan, 2006; Dull, 2006). One is left with the distinct impression that budgetary reform is both initiated and dominated by the president with the legislature as the arbiter of whether the reform becomes law or remains a failed executive initiative. The reforms discussed in this chapter will demonstrate that this far from the reality. Congress has consistently, and doggedly, pursued a better, more workable budgeting process. No doubt it is quicker and easier to focus on the executive branch, than to dig into legislative actions. However, this ahistorical treatment of budgeting has served to mislead us regarding institutional inheritances and distract us from the politics at play. It is this complexity of institutions, of ideology, of individuals, of the accretion of actions over time that makes federal budgeting such a difficult task. The increased complexity creates more tension and presents more opportunities for conflict.

Another common element across these executive reform initiatives is that they failed to gain Congressional buy-in and, as a result, were not sustained across administrations (Posner \& Fantone, 2007; U.S. GAO, 1997). This research demonstrates that lasting budget reform is not dependent on a particular branch of government, but on the support of both the executive and the legislative branches. For example, federal budgeting literature has documented the success of the Government Performance and Results Act (GPRA) with the observation that it is also the only reform supported by the legislature. However, the success of GPRA was also the success of President Clinton's National Performance Review; one reform facilitated the other. As another example, budgeting scholars also note the success of the Hoover Commission. The overlooked legislative companion to the Hoover Commission is the National Security Act of 1949, which required the Department of Defense to use performance budgeting (U.S. GAO, 1997). The following year Congress passed the Budget and Accounting Procedures Act requiring budget obligations by activity instead of by goods and services (U.S. GAO, 1997).

Regardless of whether reforms are implemented, they serve to bring attention to programs that have little or no funding and give the impression that progress is being made (March and Olsen, 1989; Salamon, 1981; Seidman, 1980). Reforms also have symbolic value for Presidents making their mark on 
new administrations (March and Olsen, 1989). As stated by Neustadt (1990), "the search for personal influence is at the center of the job being President” (p. xxi).

Driven by the fear of abuse of "imperfect human nature coupled with substantial power," the structure of our democratic system established by the U.S. Constitution serves to ensure that the branches of government do not have the power to run roughshod over each other, but instead must share power and work cooperatively to govern—separate institutions sharing power (Koenig, 1996, 31; Neustadt, 1980; Thurber, 1991; Mezey, 1991; Jones, 1994). Wilson (1990) noted that this power sharing arrangement serves to both preserve liberty and slow the progress of political change (p. 108). The young nation was focused on establishing and perpetuating itself; it was not interested in efficiency and effectiveness (Wilson, 1990). James Madison sought a balance. The legislature is responsible for enacting laws and proving funds (U.S. Constitution, Article I, Sections 1 and 8): the executive carries out the laws and provides military defense (U.S. Constitution, Article II, Sections 1 and 2). DiClerico (1990) observed that Article II of the Constitution was short and ambiguous, leaving an opening for later executives to broaden the scope of their duties. This shared power structure institutionalized a continual struggle between the branches of government in maintaining its identity and clarifying its role (Koenig, 1996; Jones, 1994).

The tension arising from this deliberately fragmented rivalry makes democracy a living thing-a battle to gain power and control. Madisonians would like a stronger Congress with a more limited presidency: Hamiltonians prefer greater discretion granted to the president. The Constitution grants Congress with legislative power, but the President is granted the authority to recommend and veto legislation. The President proposes the budget, but the authorization and appropriations of funds is granted only to Congress. A study of the evolution of the American budget process through reforms provides an excellent context from which to view this struggle between these two branches of government. Whoever controls the money controls the agenda.

\section{Importance of Institutions in Budget Reform}

The Act of September 2, 1789 (1 Stat. 65) established the Treasury Department and required that the Secretary of the Treasury provide an estimate of revenue and expenses to Congress. Subsequent Acts (May 10, 1800 [2 Stat. 79] and August 26, 1842 [5 Stat. 536]) expanded the tasks to providing plans for increasing revenue and also changed the date of the fiscal year (Willoughby, 1918). These actions made the departments the agents of Congress. 
Although Congress was granted the power of the purse by the U.S. Constitution, the system used to budget was not specified (Thurber, 1991). The study of the institutional basis of budget reform will show that the unintended consequences of the various changes to the budgeting process has deepened the struggle for power and agenda control between the legislative and executive branch. As an example, the power to raise and appropriate funds granted Congress through the U.S. Constitution was encroached upon by the addition of the president into the budgeting process through the Budgeting and Accounting Act of 1921. However, Levy (1974) concluded that the “erosion of congressional power” started in 1865 with the split of budget functions into the new Appropriations committees and the Ways and Means (and Finance) committee (p. 66). Congress initiated this legislation in order to improve the budgeting process. Bringing the executive in gave a central focus to a system of budgeting that was fragmented among the many committees of Congress. Heclo (1984) provided a succinct summary of shifts in focus of the executive budget over time: during the 1920s the focus was on controlling costs; the budgets of 1930s and 1940s served more as "accounting devices” for costs incurred during the Depression and World War II; cost control again became the focus in the 1950s; in the 1960s the budget became a tool for fiscal policy and planning domestic programs; the budgets of the 1970s were used to account for spending outside the budget process (p. 257). These changes show an expansion of tasks associated with the executive budget; from the traditional function of payments, to the setting of national priorities, to an instrument of fiscal policy (Heclo, 1984). The budget had also become an instrument of income distribution to many Americans.

Reforming government is not a task confined to the modern era. Between 1789 and 1909 a total of 206 investigations were conducted primarily concerned with accounting and reduction of expenditures. Of these investigations, 105 were conducted by Congress, 100 by federal agencies, and one by the President (Glenn, 1958). The final attempt of that era, Theodore Roosevelt's Keep Commission (190509), was an effort to strengthen the executive's role in administration through the use of new business techniques, such as lump-sum budgeting, cost accounting, and planning (March and Olsen, 1989). Congress pushed back by refusing to authorize publication of the Commission's report and by refusing to fund any future administrative commissions unless authorized by Congress (March and Olsen, 1989; Kraines, 1970; Hobbs, 1953). This tug-of-war between the executive and Congress sets the theme for such efforts. Congressional and agency driven reforms are deemed inadequate for the needs of an expanding government led by the executive branch, while executive reforms are seen as presidential overreach. For example, William Howard Taft's first attempt with reform also met with congressional resistance. In reaction to the Taft Commission's (1911) proposal of new budgeting procedures, Congress 
enacted a law forbidding the waste of the government's time on executive budgets (March \& Olsen, 1989; Hobbs, 1953; Harding, 1921).

The exploration of reform efforts, suggests that these efforts build upon one another with earlier problems re-surfacing to be examined again in the governmental garbage can of later years (Cohen, March, \& Olsen, 1972). As stated by March and Olsen (1989), "since there are few established rules of relevance and access, reorganizations tend to become collections of solutions looking for problems, ideologies looking for soapboxes, pet projects looking for supporters, and people looking for jobs, reputations, or entertainment” (p. 82). This issue recycling is part of the government and legislative process, so it is no surprise that it also characterizes efforts at budget reform, proposals made in reorganization committees are often implemented years later (March and Olsen, 1989; Chamberlain, 1946; Jones, 1994; Neustadt, 1980). Time plays a significant factor in the adoption of reforms. Recommendations made by the Brownlow Committee that were greeted by accusations of an “aggrandizement of presidential power” were regarded as a "monumental effort to bring order out of chaos” as part of the Hoover Commission (March and Olsen, 1989, p. 86; Emmerich, 1971, p. 87; Fesler, 1975, p. 101). The Taft Administration's reporting about the government economy helped create the Bureau of the Budget a decade later (Rose, 1976).

March and Olsen characterized reform as "natural experiments in governance” noting that reforms have moved initiatives from Congress and toward the president with continued congressional resistance (March and Olsen, 1989, p 70; Weber, 1919; Harding, 1921; Arnold, 1976; Pinkett, 1965; Moe, 1978). Each attempt at reforming the budget can be viewed as the originating branch's effort to control the agenda and to gain advantage. However, the culmination of the various attempts at budget reform regarding the budget has resulted in a near stasis between the executive and legislative branches. This has not always been the case. Enactment of the Budget and Accounting Act of 1921 brought a sea change to this balance of power. A review of the budget process, after the Act, demonstrates gains to the executive that peaked during the Nixon Administration. The presidencies of Gerald Ford and Jimmy Carter saw the decline of presidential budgeting power with an increase to the legislature. These gains were surpassed by the overwhelming budgetary victories of President Ronald Reagan and his Budget Director, David Stockman. However, even Reagan could not sustain his budgetary success. Congress has continued to re-assert its constitutional power of the purse. President Bill Clinton was pragmatic enough to parlay public sentiment (and momentum) about big government and waste into a call for reform. Congress, in its desire to better manage the bureaucracy and the dollars spent to sustain it, legislated GPRA forcing federal agencies to develop and meet performance measures. However, it is important to remember the 
impact of our constitutional structure of government on the adoption of reforms, which Jones considers the "bulwark against major change" (Jones, 1994).

Structural and procedural reforms initiated by Congress, made through budgetary legislation of 1974, 1985, and 1987, have shifted the balance of budgetary power from the president to Congress (Thurber, 1991). These changes have also centralized budget decision making; legislated congressional review of presidential impoundments; and restricted the power of authorization committees (Thurber, 1991). Changes within Congress through the Legislative Reorganization Act (1970), the Subcommittee Bill of Rights (1973), and the Committee Reform Amendments (1974), have shifted power from committee chairmen, to committees, to subcommittees (Shepsle and Weingast, 1984). The rise of congressional budget committees and the use of reconciliation have been at the expense of the appropriations and authorizing committees, increasing conflict within the legislative chambers (Mills, 1984). As stated by Reischauer (1984),

Reconciliation raised the visibility of the decision, denied interest groups their normal channels of influence, and prevented powerful committee chairmen from stalling and defining the dimensions of debate. By acting collectively and for a presumed greater good, members of Congress could share the blame for the bloodletting. The Budget Committees, the budget process, the president, the OMB director, and the hoped-for new economic order could be saddled with the responsibility for specific unpopular actions (p. 400).

Rule changes have allowed non-appropriations amendments to be added to appropriations bills enabling passage with a simple majority. An example of this is Senator Kay Bailey Hutchinson's (R, Texas) amendment to an emergency supplemental appropriations bill that withheld funding form listing new endangered species while other committees were revising the law (Rubin, 2006).

The president's influence over what he can change has eroded. Neustadt (1990) explained that the executive is limited in what he can directly change; instead, he has the power to persuade, to affect change though the use of others- " "persuasion deals in the coin of self-interest with men who have some freedom to reject what they find counterfeit” (p. 40). The president can use the prestige of office, public support, OMB, special interests, and the veto to influence Congress. In a 1981 budget amendment, President Reagan secured the largest peacetime defense increase in U.S. history through negotiations with key Senators (Stubbing, 1984). Reagan’s personal involvement in budget and finance bills was considered at the time to be “unprecedented in scale” (Reischauer, 1984, p. 408).

The president's veto power is asymmetrical; he has the power to reject congressional appropriations, but not to modify or add. Further, the veto can be overridden with a two-thirds majority in 
both congressional chambers. According to Kiewit and McCubbins (1988), this institutional arrangement places Congress in the position of “"monopoly proposer," submitting "take it or leave it” offers to the president' (p. 714). Institutional limitations on the president give him greater power when he prefers to appropriate less. Thus, Kiewit and McCubbins (1988) suggested that vetoes are "exercises in position taking” (p. 731).

Congress is decentralized and individualized (Wilson, 1990). Power inside Congress has shifted from strong committee chairman to individualized agents who put little stock in the seniority system (Koenig, 1996). As stated by Cheney (1990), “at its best, Congress is a deliberative body whose internal checks and balances favor delay as a method for stimulating compromise. At its worst, it is a collection of 535 individual, separately elected politicians, each of whom seeks to claim credit and avoid blame” (p. 249).

Huntington (1984) noted the challenge of the assertive Congress,

Vis-à-vis the executive, Congress is an autonomous, legislative body. But apparently Congress can defend its autonomy only by refusing to legislate, and it can legislate only by surrendering its autonomy. In the past, there has been a familiar pattern: Congress balks, criticism rises, the clamoring voices of reformers fill the air with demands for the "modernization" of the "antiquated procedures" of an "eighteenth century" Congress so it can deal with "twentieth century realities." The demands for reform serve as counters in the legislative game to get the President's measures through Congress. lndependence thus provokes criticism; acquiescence brings approbation. If Congress legislates, it subordinates itself to the President; if it refuses to legislate, it alienates itself from public opinion. Congress can assert its power or it can pass laws; but it cannot do both (p. 181).

Institutions also instill incrementalism in federal budgeting that result in small changes to the budget over time through the accretion of policy inheritances (Patashnik, 1999). Patashnik contended that these entrenched commitments create feedback effects that structure future obligations, so that budgeting becomes more about funding past responsibilities than funding new ones (such as entitlements, indexation, and trust funds). It is important to recall that these actors cannot behave independently from the institutions in which they reside. Heclo (1994) stated that "individual choices are embedded in institutional settings that privilege some options and delete others;" likewise, they benefit certain interests more than others (p. 376). March and Olsen (1984) consider institutions to be actors in their own right; "the state is not only affected by society but also affects it” (p. 738).

Ferejohn and Krehbiel (1987) found that institutions make a difference in budgeting outcomes and that this difference depends on the "configuration of preferences of actors” (p. 303). These budgeting preferences represent multiple goals of institutional agents who serve as entrepreneurs whose advocacy 
aids in subtle shifts in the institutional balance of power creating disequilibria. The ambiguity in "separate branches sharing powers" creates conflict that can result in endogenous institutional change (Neustadt 1990, p. 5).

Congress legislated a history full of changes that has altered the budgetary process for both themselves and the president. The outcome has been a budgeting process that is "complex and opaque" (Patashnik, 1999, p 153; Joyce, 1996; Thurber, 1997). The format of the budget is important because it influences policy by determining what information is used and how it is presented. For example, line item

budgets emphasize financial control; performance budgets document accountability; and program budgets best demonstrate priorities and trade-offs (Rubin, 2006). Changing the process has not made the decisions of which programs should be funded at what levels easier, nor has it made the budget easier to balance. What it as has done is obscure responsibility enabling institutions to shift the blame for its failures and give the appearance of progress under the guise of process change. As stated by Aberbach and Rockman (2000), “administrative reform proposals become a cover for deeper political change or for avoiding responsibility for hard and distasteful policy decisions” (p. 184). Others factors contribute to the executive-legislative relationships, such as institutional rules; the power decline of the national political party system; effects of divided government; the impact of public opinion and the perception of electoral mandate; the president as an individual; and exogenous shocks.

\section{Historical Budget Reform Overview}

As discussed earlier, this chapter serves to recover a past largely ignored in contemporary budgeting literature. Doing so will provide insight into the ideas, questions, and sentiment that guided the development and reform of federal budgeting. The discussion of contemporary budget reforms will begin with the Budget and Accounting Act (1921) through the life of PART (2008). We begin with the Budget and Accounting Act because it is the most important change to the budgeting process and because it pulled the president into the process.

It is important to acknowledge the relationship between administrative reforms and budget reforms. Both branches of government realized that budget process modifications were not changes that could be made without having an impact on time, labor, and the structure involved in their implementation and maintenance. As a result, alterations to the budget process were frequently incorporated into legislation that reorganized both the legislative and executive branch. Early efforts in budget reform established and worked through the fundamentals of a coordinated budget. This informed approach appears to have been abandoned beginning in the Reagan years, which coincides with the 
President's campaign against big government and the gutting of federal agencies. Perhaps, then, this is where the budget process begins to collapse, as later budget process changes are more superficial instead of substantial.

Of all the contemporary reforms instituted two are outstanding in their impact on the federal budgeting process: the Budget and Accounting Act of 1921 because it brought the President into the budgeting process and the Congressional Budgeting and Impoundment Control Act of 1974 because it returned to Congress the power it lost in 1921. Other reforms modified the budgeting process to make it more efficient and more responsive, but it is by these two reforms - both initiated by Congress — that significant and lasting changes were made.

A discussion of legislative-initiated reforms will begin this section. Executive-initiated reforms will follow. Less time will be allocated to these reforms, because executive reforms are well-trod ground. As we explore each reform we will identify which institution gained from the reform and will assess how the reform was framed. This will give us insight into what tactic was used to make the reform acceptable.

\section{Legislative Budget Reform Initiatives}

Kettl (1992) observed that "reformers have attempted to substitute process for politics” with the intent to alter the budget process in such a way that the political costs are hidden and party or congressional branch gains an advantage (p. 92). These process changes became more evident once legislators started to work on finding ways to deal with the deficit through Gramm-Rudman-Hollings (sequestration) and the Congressional Budget and Impoundment Control Act (resolution and reconciliation). It is no coincidence that both of these efforts pulled power from the president.

Nine legislative-initiated budget reforms have been identified for discussion (Table 1). Although it is expected that each branch works to further their control of the process, two congressional reforms clearly benefited the executive: the Budget and Accounting Act and the Line Item Veto. 


\begin{tabular}{|c|c|c|c|c|c|}
\hline Year & PL & Benefit & Act/Initiative & Reform Frame & Primary Reform Accomplishment \\
\hline 1921 & $67-13$ & Exec & Budget \& Accounting Act & $\begin{array}{l}\text { Govt efficiency \& economy; financial } \\
\text { control }\end{array}$ & President responsible for the budget \\
\hline 1946 & $79-601$ & Legis & $\begin{array}{l}\text { Legislative Reorganization } \\
\text { Act }\end{array}$ & $\begin{array}{l}\text { Increase legislative branch } \\
\text { efficiency }\end{array}$ & $\begin{array}{l}\text { Congress prepares legislative budget after } \\
\text { reviewing the President's budget }\end{array}$ \\
\hline 1949 & $81-216$ & Legis & $\begin{array}{l}\text { National Security Act } \\
\text { Amendments }\end{array}$ & Economy \& efficiency & Military "peformance budget" \\
\hline 1956 & $84-863$ & Legis & $\begin{array}{l}\text { Government Budgeting } \\
\text { Amendments }\end{array}$ & $\begin{array}{l}\text { Improve budgeting \& accounting } \\
\text { methods }\end{array}$ & Cost-based budgeting \\
\hline 1974 & $93-344$ & Legis & $\begin{array}{l}\text { Congressional Budget \& } \\
\text { Impoundment Control Act }\end{array}$ & $\begin{array}{l}\text { Secure congressional budget } \\
\text { control }\end{array}$ & Control the presidential use of impoundments \\
\hline 1985 & $99-177$ & Legis & \begin{tabular}{|l} 
Balanced Budget \& \\
Emergency Deficit Control \\
Act
\end{tabular} & Deficit reduction & $\begin{array}{l}\text { Demonstrated that sequestration was not a } \\
\text { solution }\end{array}$ \\
\hline 1990 & 101-508 & Legis & $\begin{array}{l}\text { Omnibus Budget } \\
\text { Reconciliation Act }\end{array}$ & Deficit reduction & Pay-as-you-go \\
\hline 1993 & $103-62$ & Legis & GPRA & $\begin{array}{l}\text { Strategic planning \& performance } \\
\text { measurement }\end{array}$ & Performance plans \\
\hline 1996 & $104-130$ & Exec & Line Item Veto Act & Deficit reduction \& spending control & Presidential control over expenditures \\
\hline
\end{tabular}

\section{Budget and Accounting Act of 1921}

The Budget and Accounting Act was framed as a way to increase financial control over government spending and make government more efficient. It succeeded in making the president an integral part of the budgeting process. Legislating the Budget and Accounting Act of 1921 was a long process involving both presidentially appointed and congressional committees including: the President's Commission on Economy and Efficiency (Taft Commission, 1911-1913); the Bureau of Efficiency (19131933); and the Joint Committee on the Reorganization of the Administrative Branch of the Government (1920-1923). The work of these committees spanned the presidencies of William Howard Taft, Woodrow Wilson, and Warren Harding.

There was much debate about the concept of a national budget that was considered by some as “undemocratic” and “un-American” (Cleveland, 1915, p. 22). The increase from a "billion-dollar country" to a "two-billion dollar Congress" angered and mobilized the public and the media to concerns regarding "boss rule” and the workings of an “invisible government” (Cleveland, 1915, p. 22). In response, Congress passed the Sundry Civil Appropriation Act of March 4, 1909, which included a clause giving the President the responsibility for recommending to Congress ways to increase revenue or reduce appropriations when the Secretary of the Treasury's appropriations estimates exceed revenue. Willoughby (1918) labeled this Act as the "first official action looking to a change in existing conditions" (p. 136). Effectively, the Act enabled the president to dip a toe into the budgeting pool. Seeing this as the advantageous opening into a congressional process, President Taft then took the initiative by directing the reduction of departmental estimates with his Cabinet members and asking Congress for money to "enable 
the President to inquire into the methods of transacting public business” (Cleveland, 1915, p. 23). With this money the President's Commission on Economy and Efficiency was created on March 8, 1911, led by Frederick Cleveland (Director of the New York Bureau of Municipal Research). Among its many reports and suggestions, the Commission recommended that a national budget system be adopted and that the President be responsible for preparing the annual budget for submission to Congress, because he was more familiar with the work of the departments than Congress and he is answerable to the American public as opposed to the narrower interests of Congress. The justification by President Taft for the inclusion of the executive in the budget process was based on the Constitution's prescription that the President shall "from time to time give to the Congress information of the state of the Union and recommend to their consideration such measures as he shall judge necessary and expedient" in the submission of "a regular statement and account of the receipts and expenditures" (Taft, 1913, p 5). Taft then sent two sets of budgets to Congress one using the current forms and another using the forms prescribed by the Commission. The budget was referred to the Appropriation Committee, ordered to be printed, and was subsequently ignored. Congress reacted by inserting text in its legislative, executive, and judicial appropriations bill reaffirming that the departments submit their estimates to Congress, not the President. Having completed his term, Taft was out of office five days later (Collins, 1917).

The work of the Commission did not stop. In 1916, the Institute of Government Research (now the Brookings Institute) was organized in Washington, D.C. to "conduct scientific investigation into the theory and practice of governmental administration” furthering the cause of reform (U.S. House of Representatives, 1919, p. 47). This independent, non-partisan organization produced multiple journals on public administration including five volumes specifically on the national budget. Its membership included leading researchers in public administration and former members of the Taft Commission (Willoughby and Goodnow) who also provided expert testimony in congressional hearings. Congress remained interested in the national budget establishing the Bureau of Efficiency (38 Stat. 1007, March 25, 1913) to carry on the Taft Commission's work.

Cleveland and Buck (1920) stated that both chambers of Congress and their majority leader's (both were Democrats) opposed the new budget system. The powerful Congressman Joe Cannon (R, Illinois) stated that by including the President in the budgeting process, Congress "surrendered the most important part of a representative government," concluding that "we had better stick pretty close to the Constitution with its division of powers well defined and the taxing power close to the people" (Cleveland and Buck, 1920, p. 352). 
Interest in budgeting gained traction in the States, as both legislative- and executive-centered budgets took root. By the time Congress again looked at the issue of a national budget, 44 (of 48) states and many cities had a centralized budget system (Cleveland and Buck, 1920). In 1916, all three political parties (including the Progressive Party) included the establishment of a national budget in its platform. The U.S. Chamber of Commerce had unanimously voted in favor of a national budget in 1912.

In 1915 the House Democratic caucus appointed a committee to explore the adoption of a budget (Collins, 1917). They were unable to agree upon a method. However, the idea of a national budget was kept alive in Congress by a few supporters. Beginning in 1915, Senator William Kenyon (R, Iowa) introduced joint resolutions to create a commission to plan the adoption of a national budget system. By 1917, Congressmen William Goodwin (D, Arkansas), Sydney Anderson (R, Minnesota), and James Frear (R, Wisconsin) took similar action in the House. Finally, in 1919 the Senate formed a special committee to develop a plan for the national budget and the Select Committee on the Budget was established in the House.

Hearings held on the national budget, conducted by the House Select Committee on the Budget in September 1919, documented Congressional concerns in establishing a national budget including: the need for a constitutional amendment; the likelihood of taxes increases; effectiveness in keeping the departments from padding their estimates and gaming the system; effectiveness of the President as the budget initiator (since Congress believed that Presidents consistently asked for too much money); and how Congress's internal structure and processes would need to be altered (U.S. House of Representatives, 1919). Congressmen expressed the general opinion that they were the restraining power over a government whose efforts were unappreciated by the media and the public. Committee Chairman James W. Good (R, Iowa) quoted Herbert Quick (“To our imperial votaresses,” Saturday Evening Post, Sept 27, 1919) in a comment that reflected the times and the national mood:

National housekeeping. That is what we need, and if you, the imperial votaresses to whom this is addressed, do not help to give it to us, it looks as if we might go on indefinitely wasting money through pure ignorance, thriftlessness, and dolessness; while Congress sits besottedly by its dirty political hearth sucking at its smelly pipe of patronage and swigging at its mug of paltry popularity - wasting money to an extent that would bankrupt any other nation, and will bankrupt us if we do not stop it (U.S. House of Representatives, 1919, pp. 398-9).

Committee members wanted the President to take responsibility— to share the blame. Congress began to see the budget system as a way to gain control over expenditures, as the executive branch audited its own departments through the Treasury with no congressional oversight. Federal spending was out of control with the nation not only paying for debt from World War I, but also still paying off Civil War debt. 
Congress established the Joint Committee on Reorganization (41 Stat. 1083, December 29, 1920) to survey executive departmental services to assess overlaps and duplication. The Committee sought to reorganize the executive branch by function (Moe, 2002). To help them with their task, the Committee sought support from the Bureau of Efficiency. At the same time, Secretary of Commerce Herbert Hoover strived to make the Department of Commerce a "super department” by folding various departments into his own (Moe, 2002). The plans submitted by other departments were also expansive. Although the Joint Committee submitted recommendations to Congress, none were adopted. Twelve years after research was begun to examine efficiency of government, the Budget and Accounting Act (BAA) (Public Law 67-13) was passed on June 13, 1921.

It is important to note that members of the Taft Commission and the Institute of Government Research (and later the Brownlow Commission) included some of the founding fathers of public administration. With their drive for economy and efficiency, and purposeful actions to rid government of patronage and excess, they set the tone for a practice that deliberately excluded the role of politics. The striving for purity of practice, while admirable, constrained development of the field. This is especially true for budgeting where the activities are inherently political. Most contemporary federal budgeting scholarship continues to overlook the role of politics.

Making the President responsible for preparing the budget for submission to Congress was key to the BAA. Concerns about the workload of the President were allayed by the creation of the Bureau of the Budget (now the Office of Management and Budget), which was formed to aid the President in budget development. The BAA also created the General Accounting Office as an independent office responsible to Congress and formed by combining the Treasury Department's six auditing offices. It also created the Office of Comptroller General. Each department was directed to establish a budget officer who took the lead in providing estimates to the president. Another important improvement was the specification of line items in the budget, as opposed to the lump sums that were used earlier. Tyler and Willand (1997) noted that line-item budgeting was politically attractive due to its lack of attention to policy issues. Later, the House Rules Committee would consider the BAA to be the "turning point in executive-legislative budget relations ... The result has been a dangerous mismatch in executive and legislative resources" (as cited in Cullather, 1985, p. 512). 


\section{Legislative Reorganization Act of 1946}

The Legislative Reorganization Act of 1946 was framed to increase legislative branch efficiency. It succeeded in giving Congress an edge over the President by having Congress prepare the legislative budget after reviewing the President's budget.

After World War II, Congress turned their focus to the reformation of the legislative branch. After a year of review and five months of hearings, where more than 102 witnesses were heard, the Joint Committee on the Organization of Congress recommended the Legislative Reorganization Act, which became Public Law 79-601 on August 2, 1946 (U.S. Cong. Rec., July 25, 1946, p. 10039). The primary sections of this law reduced the number of standing committees in both chambers; required that the committees be established at the beginning of each Congress; established the powers and duties of each standing committee; and gave the committees oversight for their respective departments. For purposes of our analysis, the most significant reform of the Legislative Reorganization Act was Section 138, which altered the budget process by requiring Congress to prepare a legislative budget after reviewing the President's budget. Under this plan the revenue and spending committees of each chamber would meet and report to their respective chambers in order to set annual appropriations (House Ways and Means and Appropriations Committees; Senate Finance and Appropriations Committees). A concurrent resolution setting the maximum monies appropriated and adopting the budget would also be submitted with the report. The Senate's Special Committee on the Organization of Congress considered the change a check on the power of the president who had "mingled appropriations, brought forward and backward unexpended and anticipated balances, incurred coercive deficiencies, and otherwise escaped the rigors of congressional control” (U.S. Senate, 1946, p. 5).

Representative John Taber (R, New York) argued against the legislative budget believing that it would,

... absolutely destroy the operations of the Appropriations Committee in the House of Representatives. It will increase spending. It will prevent any kind of orderly procedure by the House. Instead of it being a progressive, forward-looking proposal, it is a reactionary proposal and a step backward ... If this proposal is adopted and an attempt is made to set up a legislative budget on any kind of scale that is accurate enough to be any good, it means long, arduous hearing upon those items, just as our committees are obliged to give that situation (Cong. Rec., July 25, 1946, p. 10075).

Seventeen of 20 members of the House Appropriations Committee voted against including the legislative budget in the legislation on July 24, 1946. Representative Robert Jones (R, Ohio) concurred calling the bill "silly, meaningless, and an expression of a will-o'-the-wisp hope, published for political purposes, which will rise to plague Members of Congress” (U.S. Cong. Rec., July 25, 1946, p. 10078). 
Representative Taber would prove to be right; the legislative budget process bogged down as unworkable even after forming appropriations subcommittees and changing the due dates for reporting the budget. By 1949 Congress was already discussing repeal of the legislative budget. Cullather (1995) noted that Congress was not able to adopt a legislative budget in 1947; exceeded ceilings established by the budget in 1948; abandoned the idea by 1949; and repealed the legislative budget in 1970. Party politics was also a culprit; as observed by Representative Henry Styles Bridges, (R, New Hampshire) “... let us remember that it was the Democratic Seventy-ninth Congress which passed the Reorganization Act. The Republican Eightieth Congress endeavored to live up to it. The Democratic Eight-first Congress now is attempting to appeal it” (U.S. Cong. Rec., Feb 10, 1949, p. 1120).

\section{National Security Act Amendments of 1949}

The National Security Act Amendments of 1949 were framed as a way to increase economy and efficiency. It succeeded in bringing "performance” budgeting to the military.

The elections of November 1946 gave the Republicans control of both chambers of Congress. First, Representative Clarence Brown (R, Ohio) and then Senator Henry Cabot Lodge (R, Massachusetts) introduced identical bills to establish a commission to study the executive branch and submit recommendations for its reorganization. The Commission was composed of legislators from both parties, executive branch appointees, and representatives from the private sector (Moe, 2002). President Truman signed the Lodge-Brown Act on July 7, 1947 (Public Law 80-162) establishing the U.S. Commission on the Organization of the Executive Branch of Government, chaired by President Herbert Hoover. President Truman formed his own Advisory Committee on Management by Executive Order (E.O. 10072) to advise him on the Hoover Commission's recommendations.

The Hoover Commission produced 19 separate reports that were submitted to Congress over three months (Moe, 2002). A total of 72\% of the Commission's proposals were implemented (March and Olsen, 1989). Part of this success was due to the public relations groundwork provided by Hoover's special interest group, the Citizens Committee for the Hoover Report (CCHR). The CCHR had a membership of more than 700 "prominent citizens" and organized itself into Citizen Committees within the states that included local affiliates (Moe, 2002). Citing an estimated savings of $\$ 4$ billion if adopted, and coupled with horror stories of government incompetence, the CCHR disseminated information to the public and drafted legislation that it sent to Congress (Moe, 2002). In 2013 dollars, the Hoover Commission cost the “picayune sum” of about \$20 million (Finer, 1949a, p. 409). 
One of the recommendations of the Hoover Commission, supported by President Truman, was to combine the military under one executive office. The resulting legislation, the National Security Act Amendments of 1949 (Public Law 81-214), formed the Department of Defense and created the Joint Chiefs of Staff. The Hoover Commission also recommended the inclusion of budgetary and fiscal reforms to promote uniformity in military budgeting. Congress included the budgetary changes in the Amendments reasoning,

... since the armed services are the Nation's biggest spenders, it is considered entirely logical by the committee that these measures for fiscal reform should be applied initially in the armed services without waiting for their adoption on a Government-wide basis. Experience gained in the military departments can later be profitably used as these reforms are extended to other departments and agencies of the Federal Government (U.S. Senate, 1949, p. 4).

Title IV, Section 403(a) of the Amendments established a "performance budget” for the military. It required the Secretary of Defense to use the "cost-of-performance” method, which organized the budget by function, activity, or project. Operating costs were also separated from capital costs. Congress expected these budget changes to "strengthen legislative control and responsibility," with Congress retaining “its power over appropriations and expenditures” (U.S. Senate, 1949, p. 288). Congress benefited by these controls. Later, during the Johnson Administration, the military would again become the proving ground for budget reform with the Program, Planning, and Budgeting System.

\section{Government Budgeting Amendments}

The Government Budgeting Amendments (1956) were framed to improve budgeting and accounting methods vis-a-vis cost-based budgeting. Passage of the amendments was a response to President Eisenhower's reform efforts to streamline the executive branch. Congress formed the Second Commission on Organization of the Executive Branch of the Government (Second Hoover Commission) on July 10, 1953. It was, again, chaired by former President Hoover. The Commission was composed with the same requirements as the first, with the exception that there was no requirement that members be selected from both major parties. Where the first Commission was focused on administration, the second was concerned with policy and function (Moe, 1978). It submitted two volumes of recommendations to Congress in June 1955, with some of the recommendations that pertained to budgeting and finance made law through the Government Budgeting Amendments.

The Government Budgeting Amendments, Public Law 84-863 (1956) amended both the Budget and Accounting Act of 1921 and the Budget and Accounting Procedures Act of 1950. Amendments to the 
former specified that agency budget requests to the president should be developed from cost-based budgets (as opposed to obligations). The later specified that agencies should use the accrual method to account for resources, liabilities, and costs; it also called for consistency in accounting and budgeting classifications. With the exception of the use of the accrual method of accounting, the Department of Defense had already implemented these reforms through the National Security Act Amendments of 1949. Although the legislation was cast as improving budgeting and accounting its objective, as stated by Senator John F. Kennedy (D, Massachusetts) a co-sponsor of the bill, the overriding purposed was "to improve financial management within executive agencies and provide more control by the Congress over expenditures by the executive branch” (U.S. Senate, 1956, p. 251). The Democrats handed Congress greater control over the President.

\section{Congressional Budgeting and Impoundment Control Act of 1974}

The Congressional Budgeting and Impoundment Control Act of 1974 (CBICA) was framed as a way to gain congressional control of the budgeting process. It succeeded in giving Congress more budgetary control and cured Nixon of his billion-dollar impoundment habit. However the law, Schick observed, “institutionalized and expanded budgetary conflict” (Wessel, 2012, p. 48).

In an effort to reduce government spending President Richard Nixon sought to reduce expenditures in domestic programs, which were championed primarily by congressional Democrats. Convinced that the budget process needed reform, Congress formed the Joint Study Committee on Budget Control in 1972.

Using the Antideficiency Act as a guide, Nixon believed that the President had the constitutional right to impound (refuse to spend) funds from Congress for federal programs that he thought were unnecessary or overfunded. In FY 1973 alone, President Nixon impounded more than \$18 billion (Thomas, 1978). Multiple lawsuits, a 1975 dismissal by the Supreme Court, and the CBICA ended Nixon's use of impoundment deferrals and rescissions. The intent of the CBICA was to "assure effective congressional control over the budgetary process" (Cullathur, 1995, p. 514). The CBICA clarified the language in the Antideficiency Act and established procedures for the review and control of impoundments by Congress (Thomas, 1978). This was no mere clarification of roles, but a major delineation between the powers of the executive and legislative branches. In addition to removing impoundment power from the president, the Act created budget committees in the House and Senate; made CBO the scorekeeper instead of OMB; and introduced resolution and reconciliation to the budget process. By making the power more even, it became even harder to pass a budget. At the signing 
ceremony Nixon commented, “This bill is the most significant reform of budget procedures since Congress began" (Jones, 1994, p. 237). Later, Nixon would sing a different tune, "I used impoundment to restrain some of the willy-nilly spending of the massive, and now largely discredited, Great Society programs I inherited ... In 1974 Congress took the impoundment power away, thus reserving to itself the right to spend irresponsibly without constraint" (Jones, 1994, p. 238).

Representative Stephen L. Neal (D, North Carolina) would later speak of the Act's significance in a 1975 congressional hearing,

I think the Congress may have sent the goat to guard the cabbage patch when in 1921 it relinquished, by and large, the budgetmaking [sic] process to the executive branch. We have reclaimed a portion of our authority, and have rededicated ourselves to our responsibility, by enacting and implementing the Budget Impoundment and Control Act (U.S. House, 1976, pp. 11-12).

Patashnik (1999) noted that the Act granted Congress "for the first time a vehicle for making decisions on overall revenue, outlay, and deficit levels” (p. 153). Power within Congress became more fragmented with the adoption of the subcommittee bill of rights and the increase in the number of subcommittees; weakening of the seniority system; and opening hearings to the public (Pfiffner, 1991; Tomkin, 1985).

The CBICA made the budget resolution a part of the process providing a mechanism for Congress to view the overall budget. The resolution sets targets for revenue, expenses, and debt, and breaks spending into functional categories; it gave Congress the opportunity to view the deficit in its entirety, bringing "big picture” policies more into focus. It also broadened the scope of conflict. Through the CBICA, Congress was required to pass concurrent budget resolutions by May 15 and by September 15 of each year. Budget resolutions establish the targets used by the Appropriations Committee. All appropriations had to be submitted to the full House before they could be considered. If the targets could not be met, the committees made the needed changes and the budget committees collected them into a reconciliation bill (Cullathur, 1995). Essentially, Congress updated its budgeting processes based on those that existed for the president, thereby increasing its power. Patashnik (1999) contended that the timing of the CBICA was due to the collapse of three budgeting norms: Nixon weaponizing the use of impoundments for political purposes; the escalating costs of entitlement programs; and the inability to balance the budget. Ferejohn and Krehbiel's (1987) analysis of the new process demonstrated that the changes were an improvement over earlier processes. Gilmour (1990) observed, "The Budget Act was so extraordinarily popular largely because its provisions pointed to no obvious policy consequence, accommodating multiple, contradictory interpretations" (p. 80). It was a political win/win; the act was 
viewed as a way to pull more power to Congress away from the President (expressed primarily by Democrats) and as a way to reduce spending (the Republican view) (Gilmour, 1990).

Reconciliation concerns itself with the macro-level of spending (expenses greater than $\$ 100$ million) (Gilmour, 1990). The resolution sets spending totals at the functional level creating general policy; deferring to their expertise, appropriations deals with specific programs. The CBICA created two resolutions; the first required passage by May 15 to set guidelines and the second passed as binding by September 15. Resolutions are developed in the Budget committees, but are not legislation. The resolutions are voted on by the full House and Senate and are passed by a simple majority. Differences are negotiated in a House/Senate conference whose product, the concurrent resolution, is to be passed by April 15. If this does not happen, the previous year's resolution stays in effect. Using this process, a reconciliation directive is included in the budget resolution that directs committees to produce bills that meet specific spending or tax targets. The Budget committee compiles these into one omnibus bill that goes to the floor for an up-or-down vote requiring a simple majority for passage. The reconciliation process has provided some control over entitlements and has been used to cut spending and raise taxes (Gilmour, 1990). It enables the majority to get spending legislation through Congress that would otherwise not make it through a committee system (i.e. through Appropriations) where the minority can obstruct majority preferences. It gave Congress more control over the budget and it shifted power from the minority (committees) to the majority (the floor). Gilmour (1990) noted that after the CBICA deficits regularly exceeded $\$ 50$ billion; after the introduction of reconciliation in 1980 the deficit exceeded \$200 billion (p. 8).

Wildavsky (2004) stated that "reconciliation represented a permanent institutional attack on the budgetary base, opening up to negotiation the boundaries of past political contracts” (p. 91). Congress began relying more on CBO's budget or the House or Senate resolutions than the President's budget. By manipulating the baselines Congress could appear to fund programs and reduce the deficit.

Passed July 12, 1974 as Public Law 93-344, the CBICA was first fully implemented by the Ford Administration for the FY 1976 budget. Reform fervor quieted during the Ford Administration only to resurface again in the Carter Administration with Zero-Base Budgeting (ZBB). 


\section{Balanced Budget and Emergency Deficit Control Act}

The Balanced Budget and Emergency Deficit Control Act was framed as a deficit reduction measure. It might have succeeded, but was undermined before it was fully implemented. At best, it instructed Congress about the dangers of sequestration.

The CBICA was amended in 1985 by the Balanced Budget and Emergency Deficit Control Act (also called Gramm-Rudman-Hollings [GRH] after its primary co-sponsors), which required that the budget be balanced within six years and set spending targets for each of the years in between. If these targets were not met, automatic reductions (sequestration) would be enforced across all programs. The calculations that would determine sequester would made by the Comptroller General. However, more programs were exempted from sequestration than originally intended so that the bill would pass. Kettl (1992) observed that the teeth were removed from GRH when Congress and the President exempted almost $70 \%$ of the budget: social security, veteran's retirement, welfare, and other domestic programs. One of the changes that were preserved was the adoption of the first resolution with a due date of April 15. GRH originated as a floor amendment to a debt ceiling bill, which meant that it was not discussed in committee. As observed by Cullather (1995), "By enacting Gramm Rudman-Hollings, the Congress was attempting to control its own inability to manage the budget and eliminate the Federal deficit” (p. 515). The Supreme Court ruled against this legislation stating that Congress violated the separation of powers doctrine through the use of sequestration by giving its authority to the Comptroller General. According to Chief Justice Warren Burger, government institutions were purposefully created to produce "conflicts, confusion, and discordance” (Wilson, 1990). In turn, Congress enacted the Balanced Budget and Emergency Deficit Control Reaffirmation Act of 1987 (Public Law 100-119), substituting the OMB Director for the Comptroller General.

\section{Omnibus Budget Reconciliation Act of 1990}

The Omnibus Budget Reconciliation Act of 1990 was also framed as a deficit reduction measure that attempted to normalize a budget process disrupted by GRH by instituting a pay-as-you-go system. To avoid the “dead on arrival” reception greeting Reagan’s budgets, the newly elected President George H.W. Bush presented an outline of his FY 1990 budget with the invitation for Congress negotiate the budget with him (Cullather, 1995).

Gimmicks and amendments kept sequestration at bay until 1990, when both the President and Congress realized that meeting the prescribed budget targets were not possible. The Omnibus Budget Reconciliation Act of 1990 (also called the Budget Enforcement Act) was introduced by Representative 
Leon Panetta (D, California) and was signed into law by President George H.W. Bush on November 5 as Public Law 101-508 after five months of negotiation. The Act amended the CBICA and GRH by setting deficit reduction targets for 1991-1955; creating procedures for the use of sequestration; and requiring pay-as-you-go for increases in spending or decreases in revenue. If spending was greater than the specified limits, sequester would be automatic at the end of the legislative session. The legislation took social security out of the deficit calculation so that the real size of the deficit was seen. It also brought flexibility to the budgeting process by allowing changes to the budget due to emergencies and changes in the economy. The legislation tweaked the process, but did not significantly reduce the deficit. BEA was ignored at first and then was ignored again once a surplus was achieved.

Another legislative initiative was being advocated in Congress during the Bush Administrationthe Government Performance and Results Act. Senator William Roth (R, Delaware) had originally introduced the bill that would lead to GPRA in 1990 as S. 3154, the Federal Program Performance Standards and Goals Act of 1990 (U.S. CBO, 1993).

\section{Government Performance and Results Act of 1993}

The Government Performance and Results Act of 1993 (GPRA) was framed as a process to increase performance management of government programs and institute strategic planning. It succeeded in requiring federal agencies to develop performance plans.

GPRA (Public Law 103-62) was a bipartisan effort sponsored by Senator Roth with 19 cosponsors from both political parties and signed into law by President Bill Clinton. Although GPRA is heralded as an accomplishment of the Clinton Administration, the heavy-lifting was done under President Bush. Groszyk (1995) contended that the antecedents of GPRA lay in OMB’s Management Report (January 1989) completed under President Reagan and submitted to Congress in Reagan's FY 1990 budget. Firmly a Republican initiative, John Mercer, the "father” of GPRA, brought his experience using GPRA in Sunnyvale, California to Republican members of the Senate to help them create GPRA legislation (Radin, 2000b, p. 146). By the end of 1992 the Senate had approved a substitute bill, but it stalled in the House. Unlike ZBB, which was not continued into the following legislative session, GPRA was reintroduced in the next Congress as S. 20, with a similar bill (H.R. 826) introduced in the House by John Conyers (D, Michigan) (U.S. CBO, 1993). The House and Senate passed the bills on May 25, 1993 and July 15, 1993, respectively. 
GPRA required the president to use performance plans in his budget. The federal agencies were to provide five-year performance goals to OMB and Congress. These goals would be updated at least every three years. Progress on achieving the goals was reported annually to both the President and Congress. GPRA also established pilot programs in performance measurement, managerial accountability, and performance budgeting in select agencies.

Dull (2006) believed that GPRA was embraced because it complemented President Clinton's National Performance Review (NPR). Thus both Republicans and Democrats could claim success. Dull characterized GPRA as having broad but shallow support by Congress. However, congressional oversight hearings conducted in 2004 regarding GPRA concluded that it was still working. GPRA continues to have bipartisan support in Congress and has been supported by successive presidents. NPR and GPRA were companion initiatives, the first led by Democrats and the second by Republicans, which enabled each respective branch to reform government within the scope of their institutional responsibilities—reform in tandem gave neither branch an advantage. Groszyk (1995) summarized the GPRA experience,

Nothing in GPRA is new or revolutionary to the American experience. GPRA's major elements can be found in most businesses, where these have been used for decades but for a different ultimate objective: profit or loss. What GPRA seeks to create is the government's counterpart to the business ‘bottom line' (p. 4).

One of the criticisms of GPRA was its top-down, one-size-fits all approach that was particularly problematic with programs such as Community Development Block Grants (Handley, 2007). These criticisms would later be applied to PART. McNab and Melese (2003) faulted GPRA for not incentivizing federal agencies for reducing costs and gaining efficiencies.

\section{Line Item Veto Act}

The Line Item Veto Act was framed to reduce the deficit and increase the control of spending. In its short life, it succeeded in giving the president greater control over expenditures. Rubin (2006) pointed out that the Line Item Veto is misnamed; it gave the president rescission authority not the ability to veto line items in the budget. The Line Item Veto Act (Public Law 104-130), amending the CBICA, was signed into law on April 9, 1996. The Act gave President Clinton the authority to veto specific discretionary budget authority, a new direct spending item, or limited tax benefits if it reduced the deficit, did not impede essential government operations, and would not harm the national interest. In sum, the Act was a congressional extension of presidential power. 
The line item veto was hardly a new idea. The issue first surfaced in Congress in the 1840s and was codified in the Confederate Constitution in 1861 (Spitzer, 1998). The first proposal to provide a constitutional amendment to allow the line item veto originated with Representative Charles J. Faulkner (D, West Virginia) in 1876 (U.S. Senate, 1984).

Republicans advocated for the line item veto in the 1980s and 1990s in reaction to the growing number of earmarks in appropriations bills. In his January 24, 1984 State of the Union Address, President Reagan called for changes to the budget:

As Governor, I found this line-item veto was a powerful tool against wasteful or extravagant spending. It works in 43 States. Let's put it to work in Washington for all the people. It would be most effective if done by constitutional amendment. The majority of Americans approve of such an amendment, just as they and I approve of an amendment mandating a balanced Federal budget (Peters \& Woolley, no date).

Senator Orrin Hatch (R, Utah) opened a 1985 hearing on the issue with Reagan’s statement adding that Presidents Eisenhower, Grant, Hayes, Arthur, Truman, and Franklin D. Roosevelt also requested line-item veto authority. Legislatures of the $101^{\text {st }}-104^{\text {th }}$ congresses all conducted hearings on this legislation. By the $102^{\text {nd }}$ Congress, the discussion was not consideration to amend the constitution, but instead consisted of expanding the president's recission authority. Supporters of the Line Item Veto believed that federal spending could be reduced if the President could selectively veto specific items, as opposed to the all-ornothing veto power as mandated by the U.S. Constitution. Some supporters viewed this as a way to restore power to the President. Senator Alan Dixon (D, Illinois) in 1984, and Representative Dana Rohrabacher (R, California) 11 years later, made the observation that bills used to cover only one subject; the advent of omnibus legislation weakened the presidency. Opponents, such as Senator Mark Hatfield ( $\mathrm{R}$, Oregon) believed that "the line-item veto represents a significant grant of power to the President, as the Chief Executive, at the expense of the legislative branch of Government” (U.S. Senate, 1984, p. 18). Senator Hatfield pointed out that this veto power would do little to help with budgeting as it pertained only to the discretionary budget, when the greatest financial burden was in mandatory spending. Professor Peter Schultz labeled the issue as irrelevant to budget balancing, succinctly stating that the proposed legislation was an "attempt to correct institutionally what can only be corrected politically” (U.S. Senate, 1984, p. 46). The Reagan era proposals did not become law.

In 1995, as with previous efforts, the arguments were similar. Representative Billy Tauzin (D, Louisiana) saw the line item veto as a way to "enforce congressional will power, to stop deficit spending, and stop pork-barrel projects” (U.S. Congressional Record, 1995). Others wanted to exempt from veto specific types of programs, such as defense and transportation; two budgetary cash cows for pork barrel 
politics. A consistent theme in support of the measure was the fact that the governors of 43 states had line-item veto power aiding them in controlling spending.

In 1994 Republicans won control of both chambers of Congress. Led by Speaker Newt Gingrich (R, Georgia) the House outlined its agenda in the "Contract with America," which included the enactment of line item veto legislation. Spitzer (1998) observed that the line item veto was the only item in the Contract with America on which Speaker Gingrich, Senator Majority Leader Bob Dole (R, Kansas), and President Clinton agreed. The legislation that would become law was passed in the House (H.R. 2) on President Reagan's $84^{\text {th }}$ birthday (February 6, 1995).

Although the Line-Item Veto passed the House with a 294 to 134 vote, it faced stiff opposition in the Senate from members of both parties (Joyce \& Reichauer, 1997). Senator Robert C. Byrd (D, West Virginia) fiercely opposed the bill based on constitutional grounds, as did Senator Pete Domenici (R, New Mexico). Interparty tension was particularly felt by Majority Leader Dole who had been criticized by Senator Phil Gramm (R, Texas), his main rival for the Republican presidential nomination, for failing to pass a balanced budget amendment (Joyce \& Reichauer, 1997). Senator Dole secured passage of the veto by separate enrollment, leaving the conference committee to work out the differences between the House and Senate bills. The bill stalled; the House had no interest in separate enrollment and the Senate was likely to filibuster (Joyce \& Reichauer, 1997). Republicans feared that President Clinton would use the line item veto to cut defense spending (Joyce \& Reichauer, 1997). A year after the House first passed the bill, Senator Dole reached a compromise with President Clinton moving the effective date of the line-item veto to after the election in 1997. The delay was also driven by the Republican expectation that Senator Dole would win the presidency (Spitzer, 1998). The anticipated Republican control of the White House was reasonable; the Republicans gained great momentum when they won control of the House and Senate during the 1994 mid-term election—a feat not accomplished since 1954. Republicans had also gained the majority of governorships. The "Republican Revolution” could have swept Senator Dole into the presidency; however, President Clinton was re-elected with a majority of both popular and electoral votes.

Once the law was implemented in 1997, Congress found fault with the results. Bills were introduced to overturn the President's veto; legislation was proposed to expand the President's authority; and measures to repeal the legislation were also proposed (McMurtry, 2010). Multiple lawsuits were filed in the courts, two going to the Supreme Court. On June 25, 1998 the Court held that the law violated Article I, Section 7 of the U.S. Constitution. 
However, the issued did not die. Each year President George W. Bush suggested that the line item veto authority be restored to the presidency. Legislative action to do so was taken in 2001, 2004, 2006, and 2009, but none succeeded. In March 2006, President Bush sent his own bill restoring the veto to Congress, without success.

\section{Executive Budget Reform Initiatives}

According to Sheingate (2003), "it is the president who is perhaps the entrepreneur par excellence in American politics” (p. 195). No doubt the personality, experience, and communication style of individual presidents shape their relationships with the legislative branch (DiClerico, 1990; Barber, 1985). The majority of Presidents come to office with few experiences that prepare them to be an effective leader, administrator, and coalition-builder. In addition, the politics that get you to the office of the presidency are different than the politics that keep you there. Campaign politics do not build and sustain empowering coalitions; they are the politics of differentiation not unification.

Presidents have used various rational budgeting and management techniques to increase control over the bureaucracy and federal spending, such Programming, Planning, and Budgeting Systems; ZeroBase Budgeting; and the Program Assessment Rating Tool (Benze, 1985). The failure of presidents to engage Congress in developing and implementing these reforms has limited their adoption (Bordeaux, 2006). The "managerial” presidency may be good for bureaucracy, but provides little aid in the executive's push for institutional power. President Eisenhower's previous high-level experience, in the executive branch and the military, brought efficiency and an orderly flow to information handling and gathering to the White House; however, he was frequently the last to know "tangible details" (Neustadt, 1990, p. 133; Koenig, 1996).

A characteristic of recent executive budget reforms is the incorporation of performance management and its various tools and techniques. Steinmo (1994) reminded us that "reformers must design and adapt their policies to cater to the objections and desires of a huge number of interest groups and congressional constituencies," which likely undercuts the staying power of executive reforms (p. 126).

Six executive-initiated budget reforms have been identified for discussion. A summary list of executive-initiated reforms discussed in this chapter is listed in Table 2; a discussion of each reform follows. Of these initiatives only two have been codified into law: the Reorganization Act (1939) and the Budget and Accounting Procedures Act (1950). The lack of success in executive-initiated reforms is clearly visible since the 1950 . 


\begin{tabular}{|c|c|c|c|c|c|c|c|}
\hline \multicolumn{8}{|c|}{ Table 2: Executive-Initiatied Budget Reforms } \\
\hline Year & Executive & PL & Initiator & Benefit & Act/Initiative & \begin{tabular}{|c|} 
Reform Frame \\
\end{tabular} & Primary Reform Accomplishment \\
\hline 1939 & FDR & $76-19$ & Exec & Exec & Reorganization Act & $\begin{array}{l}\text { Help for the President; efficiency \& } \\
\text { economy }\end{array}$ & Presidential control over the bureaucracy \\
\hline 1950 & Truman & $81-784$ & Exec & Exec & $\begin{array}{l}\text { Budget \& Accounting } \\
\text { Procedures Act }\end{array}$ & $\begin{array}{l}\text { Process simplification \& } \\
\text { modernization }\end{array}$ & Organized the budget by functions \& activities \\
\hline 1965 & LBJ & - & Exec & Exec & PPBS & $\begin{array}{l}\text { Control expansion of governement } \\
\text { operations }\end{array}$ & $\begin{array}{l}\text { Agency awareness of planning \& program } \\
\text { objectives }\end{array}$ \\
\hline 1977 & Carter & - & Exec & Exec & ZBB & Reduce costs; increase efficiency & $\begin{array}{l}\text { Brought program managers back into the } \\
\text { budgeting process }\end{array}$ \\
\hline 1993 & Clinton & - & Exec & Exec & NPR & Reinventing government & Streamlined services; better customer service \\
\hline 2002 & Bush II & - & Exec & Exec & PART & Best results for the money & Agencies more sensitive to outcomes \\
\hline
\end{tabular}

\section{Reorganization Act of 1939}

The Reorganization Act of 1939 was framed as a way to provide help for the president to improve government efficiency and economy by giving the president more control over the growing bureaucracy associated with the New Deal. The Act was the result of committees specially appointed by the president and joint committees of Congress including: the President's Committee on Administrative Management (Brownlow Committee, 1936-1937); the Senate Select Committee to Investigate the Executive Agencies of the Government (Byrd Committee, 1936-1937); the Select Committee on Reorganization (1937-1939); and the Joint Committee on Government Organization.

Formation of the Brownlow Committee came out of discussions between President Roosevelt and Charles E. Merriam in 1935; the result was a request by the President for Merriam, Louis Brownlow, and Luther Gulick to survey the management of the executive branch (U.S. Joint Committee, 1937). Not to be outdone in the areas of reform, the Senate organized the Select Committee to Investigate Agencies of Government chaired by Senator Harry Flood Byrd (D, Virginia) on February 24, 1936. At the President's request, the House also formed the Select Committee on Reorganization chaired by Representative James Buchanan (D, Texas). In his quest to gain control of the resources at hand — thus controlling the agendaPresident Roosevelt officially formed the President's Committee on Administrative Management on March 22, 1936.

In agreement with the two legislative committees, the Brownlow Committee was to limit their research to overall administrative management. The two special legislative committees would focus on detailed studies of the departments, for which they hired the Brookings Institution. Driven by the words "the President needs help" and with a goal of achieving efficiency and economy, the Brownlow Committee set forth recommendations that served to strengthen the Executive branch (President's Committee, 1937, p. 5). The crux of the Brownlow Committee’s January 1, 1937 report was that the President needed more administrative authority over the management of the executive branch. The 
Brownlow Committee also recommended that the Bureau of the Budget provide clearance for departmental regulations of internal management; review proposed legislation coming out of the departments; and clear Executive Orders. It recommended that modern accounting and reporting practices be adopted and standardized throughout the departments. Members of the Brownlow Committee recognized the tension between the executive and legislative branches, including the "accountability of executive to the Congress” as a separate, but small section of their report.

House committee hearings on the Brownlow Committee's report began in January 1937 and in the Senate in August. In both sets of hearings, legislators expressed concern with the growth of the federal government, concluding that the Brownlow recommendations amounted to granting the President “unlimited” power (President’s Committee, 1937). Brownlow Committee members were repeatedly pressed for detailed reorganization recommendations for the bureaucracy. Seeing this line of inquiry as politically treacherous ground, the Committee members consistently refused to be drawn into the details, stating that it was beyond their scope of work (U.S. Senate, 1937).

On the congressional side, the Brookings Institution submitted more than 1,000 pages of text to the legislative committees. Their recommendations to Congress both overlapped and challenged the Brownlow Committee’s recommendations (Polenberg, 1966). Polenberg (1966) recalled that fiscal management was the issue that caused the split between the two groups. Different treatment of the role of Comptroller-General was source of the problem. But the heart of the differences between the Brownlow and Brookings Committees was the balance of power between the President and Congress. Each committee favored their own client. Brownlow advocated for the President, weakening the role of Congress. Brookings sought to enhance Congress, fearing that politics would impair the President's administrative reliability (Polenberg, 1966). Brookings knew the reorganization plan needed congressional support. While the Brownlow Committee specifically sought a neutral, "scientific” path, Brookings acknowledged the political nature of the reform from the outset, "the national administrative organization, with its vast and far-flung personnel and its varied forms of service and assistance to different sections of the electorate, provides an obvious instrumentality for the use of political power" (U.S. Senate, 1937, p. 10).

In 1937 President Roosevelt submitted a bill to Congress that included many of the Brownlow Committee's recommendations — it was defeated. Two years later, the President submitted a bill that included only the recommendations regarding the increase in staff and authorization to submit reorganization plans for the executive branch, changes that were enshrined in the Reorganization Act of 
1939. The Reorganization Act of 1939 (April 3, 1939, Public Law 76-19) “institutionalized presidencycentered government” (Skowronek, 2008, p. 15). Through the Act, Congress reduced the President's span of control by eliminating and consolidating the number of agencies reporting to the president and by establishing the Executive Office of the President. Later, at the request of President Harry S. Truman, the Reorganization Act of 1945 (Public Law 79-263, December 20, 1945) would grant departmental reorganization power to the President with fewer restrictions than the earlier Act of 1939.

\section{Budgeting and Accounting Procedures Act of 1950}

The Budget and Accounting Procedures Act of 1950 was framed as an effort to simplify and modernize the budget process by organizing the budget by function and activity. President Truman was one of a limited number of presidents who governed with budget surpluses. This allowed the President to focus reform on process improvement and simplification.

The Budget and Accounting Procedures Act of 1950 (Public Law 81-784) was signed into law by President Truman on September 12, amending the Budget and Accounting Act of 1921. The law authorized the president to determine the form of the budget and agency estimates, and simplify federal accounting procedures. It also made the General Accounting Office responsible for establishing accounting and auditing standards. In his signing statement President Truman called the law the most important legislation enacted by the Congress on the budget since the Budget and Accounting Act 1921. Like the National Security Act Amendments before it, the law specified that the budget be organized by function and activities. The bill was initially drafted by the U.S. Commission on the Organization of the Executive Branch of Government (the first Hoover Commission, 1947-1949) and was introduced in the Senate by Senator Joe McCarthy (R, Wisconsin) in 1949. Beyond its importance in making the budget more workable, the Act also gave the president greater control.

\section{Programming, Planning, and Budgeting System}

The Programming, Planning, and Budgeting System (PPBS) was framed as an aid to control expanded government operations. It succeeded in making planning a part of the budget process in federal agencies and started agencies thinking about program objectives.

Novick (1968) traced the origins of PPBS to the writings of Donaldson Brown in the 1920s, who devised a similar system at the DuPont Corporation and later for General Motors, which were later adopted by Ford Motor Company and the RAND Corporation. One of those RAND analysts, Robert McNamara, brought PPBS to the executive branch when he served as Secretary of Defense under 
Presidents John F. Kennedy and Lyndon B. Johnson. An unacknowledged DOD employee recalled, "PPBS was designed to establish the Secretary's control over the Department of Defense" (U.S. Department of Defense, 2004, p. 6). PPBS was implemented at DOD in six months and was first used to prepare the FY 1963 budget in January 1962. PPBS was so effective for McNamara's purposes that President Johnson mandated its use by all federal agencies on August 25, 1965. That year 350 employees were hired in 21 agencies to work on PPBS integration (Rose, 1976). President Johnson advocated the adoption of PPBS as a way to help solve problems created by the expansion of social programs.

A Senate subcommittee of the Committee on Government Operations conducted a series of five separate hearings specifically on PPBS from August 1967 through December 1969. With these hearings the Senate sought to understand the system and how it worked, and to determine if it could help Congress. Senator Edmund Muskie (D, Maine) concluded the first hearing by expressing to the BOB Director his hope for suggestions for ways Congress could take advantage of PPBS “not to rubber-stamp the Executive but to challenge the Executive, because that is the purpose of the system” (U.S. Senate, 1967, p. 52). The following year Senator Howard Baker ( $R$, Tennessee) expressed interest in receiving the raw data generated by PPBS (U.S. Senate, 1968). Although there was bipartisan consideration of using information gleaned from the use of PPBS, its implementation issues and other problem prohibited its use.

PPBS is a method used to create budgets based on planning and program objectives, as opposed to the traditional incremental, line-item budget. PPBS brought concepts of economics into the budget process, such as cost-benefit analysis. Schick (1969) noted that McNamara’s DOD-tailored program was added to the regular budgeting process in the other agencies; the agencies were not permitted to create their own PPB systems, nor did they have the money to hire experienced RAND analysts as did McNamara. Other problems with PPBS included the heavy workload required; few analysts had PPBS training; and the new system ignored both budgeting traditions and politics. It is this failure to consider budgeting traditions and the vast amount of data analysis this method required that impeded PPBS success outside of DOD (Joyce, 1993; Kelly, 2003). However, as stated previously, PPBS is still used to compose the agency budget in DOD. As summarized by Rose (1976), “One moral of the PPBS experiment is that politicians do not wish to have their objectives prescribed to them by men with doctorates in economics” (p. 4).

Scholars also noted that the failure of PPBS was primarily due to "ferocious" congressional resistance (Mosher, 1969). However, PPBS advocates did little to integrate PPBS into the legislative process (Bordeaux, 2006; Botner, 1970; Schick, 1973). Utilizing the writings of Wildavsky and Mosher, 
Bordeaux (2006) explained the challenges in adopting PPBS even with legislative support, including: the difficulty reaching consensus on program objectives due to the separation of powers; cross-cutting the committee structure "in effect dictating a restructuring of power relationships between legislator and client constituencies;" and the data obtained was too abstract for a legislature that lacked capacity (p. 1234). PPBS was supposed to help make the best choice among multiple preferences. It failed.

In his 1968 Senate testimony regarding PPBS Dr. James Schlesinger, Acting Deputy Director of the Bureau of the Budget, stated “ ... I want to make clear that the effective use and further development of PPB techniques have President Nixon's wholehearted support” (U.S. Senate, 1968, p. 306). He also stated that the Nixon Administration planned to institutionalize PPBS. Contrary to these statements, President Nixon dropped PPBS.

\section{Zero-Base Budgeting}

Zero-Base Budgeting was framed as a method to reduce costs and increase efficiency. It succeeded in pulling program managers back into the budgeting process. It is also the only rational budgeting reform initiated by Congress.

Although the budgeting and reform literature casts ZBB as an executive reform brought to the federal government by President Carter, the legislature was already discussing its use in evaluating federal programs before Carter took office. The earliest bill to propose ZBB legislation was introduced in the House in 1973. In 1976 the Task Force on Budget Process conducted hearings specifically on the use of ZBB. Proponents welcomed legislation requiring ZBB's use as a way to balance the budget; control the bureaucracy; provide oversight; eliminate duplicative and un-needed programs; and create economy and efficiency. One of their greatest concerns was the duplication of effort between and within agencies.

Schick testified that more than three dozen bills pertaining to ZBB and sunset provisions were introduced in the legislature in the 94th Congress. The most successful was Senator Edmund Muskie’s (D, Maine) Government Economy and Spending Reform Act of 1976 (S. 2925), which mandated the termination of authorizations of federal programs and tax expenditures after five years unless reenacted (Sunset bill). The bill required the use of ZBB to evaluate federal programs; first by the executive branch for inclusion in the President's budget; and then by the legislative committees assisted by GAO and CBO. It was a bipartisan effort; S. 2925 had 55 cosponsors, including conservative Republican Barry Goldwater (Arizona) (Rourke, 1977). Critics believed that ZBB would greatly increase their workload and increase 
cost. One of the difficulties the legislature faced was that no one knew exactly how many federal programs were in existence. A similar bill, H.R. 11734, was introduced in the House of Representatives.

On September 15, 1976, the Senate Rules committee drafted a report on S. 2925 without recommendation. Essentially the Committee approved of the bill, but believed it needed further consideration; however, the session was nearly over (U.S. Senate, 1976b). In the House, the Rules committee held a day of hearings, but took no action. With the session nearly over, the sun set on the Sunset Bill. Thus, Congress had already favorably considered using ZBB before President Carter took office.

With the next legislative session came a newly elected president. President Jimmy Carter was a stranger to inside-the-beltway politics having previously served as Governor of Georgia. He believed that this outsider status was what got him elected. Carter was an activist president who was primarily interested in energy, the environment, and deregulation (Jones, 1994). However, Congress was still smarting over the actions of Nixon and reasserted itself by denying the President many of his agenda items. Congress was striking back at an overreaching president and the Republicans sought retribution from the Democratic-led punitiveness of Watergate. Koenig (1996) explained that it was “... Carter's cherished image as outsider that ruffled congressional sensitivities, his steep decline in public opinion polls, and the disinclination of himself and his staff to push their legislative proposals vigorously enough to gain enactment” that impeded his legislative success (p. 155). In addition, 1973 brought the first use of electronic voting bringing transparency and visibility to congressional behavior and further complicating and already difficult relationship (Edwards, 1980).

The reform-minded Carter appointed several task forces, led by OMB Director Bert Lance, to move his agenda. His major activity regarding budgeting was the April 19, 1977 implementation of ZBB, which he successfully used in Georgia. Herzlinger (1979) characterized ZBB's implementation as a “slovenly and indifferent manner that guaranteed its failure” (p. 11). President Carter was heavily invested in the use of ZBB participating "at all stages_-exhorting and selling the Cabinet, meeting with agency careerists assigned to ZBB implementation and commenting upon ZBB progress reports” (Haider, 1977, p. 402). The President had read of the method developed in 1969 at Texas Instruments in the Harvard Business Review (Tyler \& Willand, 1997; Phyrr, 1977). Burrows and Syme (2000) have traced ZBB’s concepts to Charles F. Bastable’s 1892 text, Public Finance. Although effective in state budgeting, the process was too difficult and time consuming on a national scale. The Department of Agriculture had 
used a version of ZBB in 1962 for the FY 1964 budget estimates; the process was considered a failure (U.S. House, 1979). Tyler and Willand (1997) described the ZBB system:

The concept called for identification of decision units, decision packages, ranking of units within packages and evaluation of alternative spending levels for units in the packages. Managers were to provide estimates of different levels of funding, such as below current levels of support, maintenance of the current level, or higher level of support with explanation of the impact of such alternative funding levels upon their program (p. 199).

Lauth (1978) explained that this ranking process resulted in more programs receiving funding decreases than increases for those programs at the margin (i.e., programs above and below current funding). The intent was to have agencies submit decremental budget requests that were less than current funding levels (i.e., below the base). The ZBB labor burden was high. Draper and Pitsvada (1981) reported that ZBB caused the amount of budget material in the Consumer Product Safety Commission to expand 30 times and caused "health problems in one agency" (p. 79). However, the authors found that the House Appropriations committee had no problems in using ZBB budgets as backup to the traditional styled budgets as long as the packages matched the listed items.

Herzlinger (1979) summarized that "Procedure and purpose became inverted in importance; ZBB drove out the analysis and substituted the mechanics” (p. 10). ZBB also required that program managers be included in the process, which reversed the trend set by earlier reforms (Schick, 1978). Schick (1978) concluded that ZBB did not change budgeting rules, but instead changed the terminology.

Benze (1985) found that agencies’ views about budgeting was driven more by their view of the President's role in budgeting, as opposed to the method used. In his survey of federal agency executives, $65 \%$ of respondents evaluated federal budgeting as positive vs. $18 \%$ negative. However, when specifically asked about ZBB the results were 32\% positive and 68\% negative. Thus, Benze (1985) concluded "from a bureaucratic perspective, presidents are likely to have a greater impact on the budget process through OMB, budget clearance, and increased influence in Congress than through any particular budgeting technique” (p. 776).

John W. Gardner's (Chairman of Common Cause) observation on reform before the Senate's Committee on Government Operations in 1976 is worth citing in its entirety,

Each President comes into the Oval Office and after the first 2 or 3 months, as in the case of President Truman, discovers that the buttons on the desk are not connected with anything, and he is terribly upset. He looks around and says, "Well, it must be all those little fellows with the green eyeshades. It is that vast bureaucracy that's frustrating me." So he calls in a distinguished figure. Roosevelt called in Louis Brownlow, Truman brought in Hoover, LBJ had Ben Heineman, Nixon had Ash. And if you read through the 
commission reports from Brownlow to Ash, you will find all the answers on executive reorganization. So each President studies the report from his distinguished advisor, and he goes bravely to the door labeled "Executive Reorganization," ready to open it and take on the little fellows with the green eyeshades. But what he finds facing him when he opens the door is not the bureaucracy. What he finds facing him when he opens the door are all the constituencies that made his candidacy viable and put him into office. He closes the door gently and that is the last you hear about it until the next President comes in and gets his Committee on Reorganization (U. S. Senate, 1976a, pp. 223-224).

President Ronald Reagan dropped ZBB upon taking office. Benda and Levine (1990) claim that Reagan realized that control over spending would be more effective through the political control of appropriations instead of process reform that "yields more paper than product” (p. 114).

\section{National Performance Review}

The National Performance Review was framed, by President Bill Clinton, as an opportunity to reinvent government. It succeeded in streamlining government services and provided a more customer service orientation to the public. Kelly (2003) stated that “when a 'big idea' mirrors a fundamental shift in public opinion about the enterprise of government and the role of the budget in that enterprise, the big idea endures” (p. 311). The big idea for the Clinton Administration was using the wave of public sentiment that believed the government was too large that began during the Carter Administration, gained fierce momentum under Reagan, and was sustained through the Bush Administration. Once in office, the Clinton Administration adapted ideas from Osborne \& Gaebler's Reinventing Government, How the Entrepreneurial Spirit Is Transforming the Public Sector (1992) into the National Performance Review (NPR). Osborne \& Gaebler called for the adoption of performance budgeting. NPR also incorporated many ideas from GPRA. Tyler and Willand (1997) reported that David Osborne had also advised the Clinton Administration on how to incorporate reinventing reforms in the Progressive Policy Institute's Mandate for Change (1993) where he also called for the establishment of a performance-based budgeting system. The NPR initiative, led by Vice President Al Gore, began in March 1993.

The product of NPR's six-month review of government operations was the publication "From Red Tape to Results: Creating a Government That Works Better \& Costs Less” in September 1993. The report documented actions to be taken by federal agencies, as directed by President Clinton, as well as recommendations for Congress. Clinton implemented the plan through executive orders. These recommendations were projected to save $\$ 108$ billion over five years. Additional recommendations were made two years later, bring the total number of agency-specific recommendations to 440; an additional 250 cross-cutting recommendations were made that pertained to regulatory issues and government systems (U.S. GAO, 2000). A 2000 GAO review of NPR found that it could not isolate NPR's 
effectiveness from other reform efforts, such as GPRA. The review concluded, "Congress also played an important role in supporting the agencies' implementation of NPR recommendations” (U.S. GAO, 2000, p. 8).

\section{Program Assessment Rating Tool}

The Program Assessment Rating Tool (PART) was framed by President George W. Bush as an aid that enabled the public to get the best results for the money. PART was adopted in 2002 as a centerpiece of the president's budget and performance integration initiative. The tool was used to assess federal program performance and to determine the level of program funding or elimination. PART was first used for the fiscal year FY 2004 budget. The framework consisted of a standard questionnaire that included between 25 and 28 diagnostic questions based on program type. Depending on the responses to the questionnaire, the rated program received a weighted numeric score that ranged from 0 to 100 . The four areas of assessment and their weights include program purpose and design (weighted 20\%), strategic planning (10\%), program management (20\%), and program results (50\%). A program was then awarded one of four ratings, including ineffective (a score ranging between 0 and 49), adequate (a score between 50 and 69), moderately effective (a score between 70 and 84), and effective (a score between 80 and 100). A program was given a rating of Results Not Demonstrated (RND) if the OMB determined that it lacked good performance measures or credible performance data.

The development of PART was partly motivated by the need to strengthen the link between GPRA and the budget process (Daniels, 2003). As stated by OMB in 2003, “through the President's Budget and Performance Integration Initiative augmented by the PART, the administration will strive to implement the goals of GPRA” (U.S. OMB 2003, p. 9). Growing frustration with federal agency GPRA compliance provided fertile ground for Republican staff, conservative think-tanks, and the public management community who were committed to performance management and who advocated that the President get control of the process (Dull, 2006). Two conservative Republican organizations, The Performance Institute and The Heritage Foundation, advocated the adoption and use of PART. The Performance Institute, a performance management consultancy that would later be a PART witness in congressional committee hearings, conducted a series of transition dialogue sessions in 2000 one of which was on management and performance improvement. This focus group of 40 invitees included congressional, OMB, GAO, and other federal agency staff; nonprofit and interest groups; and academics. Members from attendant groups such as the National Academy of Public Administration (NAPA), Council for Excellence in Government, OMB Watch, Citizens Against Government Waste (CAGW), and George Mason University’s Mercatus Center would later provide congressional hearing PART testimony. 
Perhaps most important to PART's emergence and development was the participation of Robert Shea, then-staff member to the Senate Government Affairs Committee, who would later drive the PART effort at OMB. This working group produced a recommendation to "show leadership on performance and management issues: consistently, aggressively and strategically support reformers within government” (DeMaio, 2000, no page). The Institute held an Environmental Performance Summit in December 2004 with the intent of gaining congressional support for PART (Gemen, 2004).

The Heritage Foundation produced a federal budget for the Bush transition that urged the president to get control of GPRA, stating that "President Bush and his Administration must not ignore the GPRA's serious potential to drive a wedge between executive branch programs and effective presidential oversight” (Antonelli and Sperry, 2001, p. 16). They concluded that a "program-by-program evaluation of federal spending can yield billions of dollars in savings and lay the groundwork for needed reforms" (Antonelli and Sperry, 2001, p. 27). The Heritage Foundation would also later testify in Congress in support of PART.

Perhaps one of PART's greatest accomplishments was the speed and breadth by which it was implemented. From the time of its inception to the last series of assessments performed under the Bush Administration (released by the OMB on September 12, 2008) PART had been used to assess $98 \%$ of all federal programs (1,015 federal programs) (U.S. OMB, No Date a). However, the impact of these assessments on decision-making was mixed. At the executive level, data suggest that there was a direct link between PART assessments and allocations in the executive budget (U.S. GAO, 2004b; Norcross \& McKenzie, 2006; Olsen \& Levy, 2004; Gilmour \& Lewis, 2006a, 2006b). There is also some evidence that the implementation of PART influenced decision-making within the agencies, albeit at a more limited level. A 2008 GAO survey based on an analysis of 2,943 responses from federal managers grade 13 and above indicated that $23 \%$ of federal managers were familiar with PART and that $37 \%$ of these used the tool in management decision-making (U.S. GAO, 2008). Fourteen percent of the managers viewed PART as contributing to improved performance.

Criticisms relating to the PART rating framework have been frequent since its inception. PART has often been referred to as a flawed tool that produces poor quality outcomes. It was criticized for its focus on executive priorities at the expense of other stakeholders; considered overly subjective due to the dependence on OMB raters; judged as not reflecting multiple program goals; scores low for following congressional requirements; exhibits bias against certain program types (e.g., community development block grants and crosscutting programs ); is labor-intensive; and performs poorly in capturing long-terms 
goals in areas such as research and development (Hughes, 2006; Radin, 2006; Gilmour \& Lewis, 2006b; Mullen, 2006).

Radin (2005) raised similar concerns in her testimony to a Senate Homeland Security and Governmental Affairs subcommittee, providing six reasons why PART was an unacceptable tool for congressional use: PART does not recognize the multiple and conflicting goals of federal programs; PART treats all programs in the same manner; OMB raters have a limited perspective; information used in PART scoring is not value-neutral; OMB does not recognize agency limitations in collecting new data, such as the Paperwork Reduction Act and the lack of funds for data systems; and the executive focus of the PART is not compatible with the legislative branch.

It is important to keep in mind that the natural friction between the executive and legislative branches has been particularly strained by Presidents seeking to increase their power and control. President George W. Bush’s encroachment into legislative territory limited support for his initiatives. The President increasingly used signing statements in an effort to reduce the effectiveness of legislation (Cooper, 2005). President Bush issued Executive Order 13450, “Improving Government Program Performance,” which codified key elements of PART. It also created a performance improvement council within the OMB; directed agencies to appoint a performance improvement officer; required agencies to establish performance management plans; and required the inclusion of performance measurement data into budget requests.

The origins of PART may perhaps best be understood in the context of the global public management revolution, which took place in the 1980s and throughout the 1990s. Within this context, the PART initiative can be viewed as an outgrowth of the most recent phase of the American public management reform movement. This reform movement was formally initiated in 1993 (almost a decade after the Westminster-style reform movement had been initiated in New Zealand) with the Clinton Administration’s “reinventing government” campaign.

Similar to previous initiatives to implement government-wide performance budgeting at the federal level, PART was not sustained following the Obama presidential transition. In his confirmation hearings, the Obama Administration's first OMB Director, Peter Orszag, raised concerns about the effectiveness of PART arguing that most federal officials are unaware of the tool and that those who are knowledgeable about it fail to use it. Orszag stated that this lack of interest and awareness of PART was 
partly a result of the tool having been “...developed without consultation with Congress and the agencies” (U.S. Senate, 2009).

\section{Conclusion}

Thus, both the executive and legislative branches of government have struggled to achieve a working budgetary system that is responsive to the electorate; helps them gained institutional control; and favors their party platform and attendant ideology. They framed their actions under the guise of efficiency and economy; process simplification and modernization; deficit reduction; government reinvention; and getting the best results for the money. Both institutions used these frames, selecting those which best fit the political, economic, and societal issues of the time. The reforms brought us far from our original process, but have taught us more about what does not work than deliver an efficient or equitable process. Whether originating in the business world or as a working solution borrowed from the States, the budget has become a mishmash of adopted ideas accreted into a tool that struggles to be workable.

The history of budget reform shows that the reform initiator is not always the reform beneficiary. Although Congress initiated the BAA and the Line Item Veto Act, these reforms primarily benefited the President. Beyond value toward the general good of government, it would be a stretch to consider any executive-initiated reform as a beneficial to Congress.

After the BAA shifted budget power to the President, the reforms that followed incrementally tweaked the budget process, but did little to help Congress regain the power that was lost. The CBICA was the defining Act that brought institutional budgeting power back toward balance.

In addition, the exploration of budget reforms demonstrates that not all contemporary, executiveinitiated reforms have been unsustainable. Roosevelt's Reorganization Act and Truman's Budget and Accounting Procedures Act survived their creators because these presidents chose to pull Congress into the process and codify the reforms. Subsequent presidents chose not to take this path.

Using PART, the most recent budget reform effort, the following chapters examine in greater detail how the tension between the executive and legislative branches of government interferes with budget reform. They will demonstrate congressional sentiment regarding PART and provide insight into how legislator's personal experiences and ideology affected their view about this most recent reform. 


\section{Chapter 3}

\section{Congressional Use of PART: Legislative Sentiments}

The history of management improvement in the federal government is a story of inflated rhetoric, shifting emphasis from one fashionable managerial skill to another, and a relatively low level of professional achievement. No president has been able to identify any significant political capital that might be made out of efforts to improve management except for the conservative purpose of economizing or reducing costs.

Marver H. Bernstein (1970, pp. 515-516)

The previous chapter explored what made historical budget reforms sustainable. This chapter offers insight into the extent the U.S. separation of powers structure interferes with the implementation of government-wide performance measurement systems at the federal level by examining the congressional resistance to PART. PART was adopted in 2002 as a centerpiece of President George W. Bush's budget and performance integration initiative; an initiative aimed at ensuring that federal dollars produce the greatest result (U.S. OMB, 2006). However, similar to previous executive reform initiatives, PART was not sustained following the presidential transition. Consistent with the notion that the separation of powers give rise to a contest of the control of power, previous research has shown that a likely and important contributing factor to why PART did not gain a foothold in Congress was a failure to gain legislative buy-in that PART could be a useful decision-making tool (U.S. GAO, 2008; Gilmour \& Lewis, 2006a, 2006b). As noted by Gilmour and Lewis (2006b), PART was perceived as a political tool used by the Bush Administration to gain support for its own policy preferences.

This research examines the extent Congress was exposed to PART and how legislators' overall sentiment toward the tool changed during the six years it was utilized. In contrast to previous research, this study examines changes over time in exposure and legislators’ sentiment toward PART.

Two sets of analyses were conducted, including an aggregate level analysis and a more detailed content analysis of references to PART. The aggregate analysis was aimed at examining trends in congressional PART exposure during the life of PART, which includes the $108^{\text {th }}$ (2003-2004), $109^{\text {th }}$ (2005-2006) and the $110^{\text {th }}$ (2007-2008) congresses. The content analysis provides insight into how legislative sentiment toward PART changed. Both analyses were based on PART-referenced data collected from congressional committee hearing reports published from 2003 through 2008.

The aggregate analysis suggests that congressional PART exposure was moderate with exposure to PART increasing over time. The more disaggregated level analysis revealed that legislative sentiment toward PART was initially negative, but gained support. Direct legislative involvement in discussions 
about PART increased, especially among Republican legislators.

These findings are important for several reasons. First, they contribute to a more comprehensive understanding of the extent to which the separation of powers interferes with the implementation of budget reform. The disaggregated level analysis reveals that PART was gaining some support toward the end of the Bush Administration, particularly among Republicans. Congressional resistance toward PART has often been attributed to the notion that it has been perceived to be a political tool that was strategically used to create an advantage for the executive branch. However, the findings show that this negative perception of PART diminished over time, suggesting that continuous exposure to an executive performance tool such as PART may have succeeded in eliminating barriers to implementation.

Second, the findings are important from a comparative perspective as the challenges faced by U.S. governments, and most parliamentary systems of government, that seek to adopt and implement government-wide administrative tools. In contrast to the U.S. form of government, most parliamentary systems are not challenged by a separation of powers structure. Parliamentary forms of government, such as Great Britain and New Zealand, enjoy a significant concentration of power that tends to facilitate reform efforts by simplifying the process of agreeing on program goals and agency objectives. This likely explains why the implementation of the Westminster reforms was speedier and less incremental, compared to the U.S. reforms.

Finally, the findings add to existing body of knowledge of why another budget reform had no staying power. Over the years, a number of executive reforms have been adopted with the aim of integrating information about program performance into the federal budget process. A common element across these reform initiatives is that they failed to gain congressional buy-in and, as a result, were not sustained across administrations (U.S. GAO, 1997; Posner \& Fantone, 2007).

\section{Research Approach}

Comments made by legislators regarding PART were identified using committee reports from 2003-2008 to determine congressional use of PART. The committee reports were gathered from the GPO Access and the ProQuest Congressional databases using the search criteria of "program assessment rating tool” and "PART.” Two sets of analyses were carried out for purposes of examining congressional exposure and sentiment towards PART; an aggregate analysis aimed at examining congressional exposure to PART during the full six years it was in use and a content analysis of references to PART for purposes of offering insight into congressional sentiment. The aggregate analysis examined PART exposure at 
different units of analysis including both chambers combined, across chambers, across party affiliation, and across committees. The content analysis examined the content of the comments captured in the aggregate analysis by coding statements from the committee reports. A total of $92 \%$ of the responses were similar for the two independent coders. These data comprised the core dataset. The collection method is one limitation of the research. Congressional committees are regarded as the workshops of congress, which is why committee reports were selected to obtain data. It is possible that the databases used did not include all published reports. In addition, some committees may not have published a report and made it accessible to the public. The second limitation is that bargaining and discussion regarding appropriations occurs outside of published sources, which limits accessibility to documented congressional opinion.

Three hypotheses are explored in this research. The first is that overall congressional exposure and interest in PART is low. This expectation is partly based on the challenge that arises from the separation of powers. This structure limits the prospect of progressive reform initiatives such as PART, because Congress and the President often differ in their perceptions of the value of executive administrative reform initiatives. Congress generally perceives these as being politicized by the President and created for purposes of shifting policy control away from Congress (Moe, 1985). Therefore, Congress has limited incentive to support and use an executive tool such as PART. The fact that PART was intended to be used as a budgeting tool likely increased legislative sensitivity. The expectation is also based on Lindblom's concept of incrementalism, which is the antithesis of progressive-style budget reform initiatives. Lindblom (1959) explained that policy made incrementally helps to avoid unintended consequences; small problems made as a result of new policy are easier and quicker to resolve. Finally, the expectation that overall congressional exposure and usage of PART is low is based on anecdotal evidence that indicates limited interest and exposure to PART among legislators (U.S. GAO, 2008).

The second hypothesis is that congressional exposure to PART increased both in terms of intensity and breadth across congressional committees during the initial three years it was utilized, followed by a decline or stabilization in exposure during the remaining three years. Increased exposure is expected partly because of a rapid increase in the number of programs that were PARTed during the six years the tool was used. Starting in 2003, the OMB evaluated approximately 20\% of all programs each year using PART. As of January 2008, OMB had PARTed 98\% of all federal programs (1,015 programs) or \$2.6 trillion of government spending (U.S. OMB, No Date b). Increased congressional exposure to PART is also expected as a result of OMB-imposed requirements that agencies incorporate PART assessments into their congressional justification materials. This requirement was imposed on the agencies in the form of a memorandum by former OMB Director Mitch Daniels and was later formalized 
in language inserted in OMB Circular A-11, which required agencies to include their PART ratings, targets, and undertakings for improving programs in their budget requests (Daniels, 2003).

Finally, increased congressional exposure to PART is expected as a result of the enhanced timeliness by which PART assessments were completed and published. A large portion of the PART assessments that were initiated during the initial three years of PART implementation were not completed until after budget deliberations had been made (Pfeiffer, 2007). All PART assessments had been completed and released by spring or early summer of 2006, which was also the first year it was effectively used to guide agency and OMB budget decisions. Given that the timeliness of the assessment increased over time, it is reasonable to expect that the inclusion of PART information in congressional justification material has increased along with congressional exposure to PART.

The expectation that congressional PART exposure stabilized or declined during the latter half of the six years is partly grounded in congressional committee statements that suggest the inclusion of PART information in congressional justification material lead to a build-up in congressional resistance toward PART. This resistance is perhaps best exemplified by statements made by the Appropriations committees, which are the most likely users of PART information. In particular, the House Appropriations committee encouraged the Bush Administration to use a meaningful system of evaluation to justify proposed program funding levels and requested that departments submit their budget justification in the "traditional format” (U.S. House of Representatives, 2006d, p. 238). The Senate Committee on Appropriations also declared its displeasure with PART by stating that "the PART analysis appears to be overly subjective and designed to reach certain preconceived conclusions about a program's validity and accomplishments and its budget needs” (U.S. Senate, 2006, pp. 5-6). Thus, both chambers of Congress reprimanded these agencies for their increased use of PART data at the expense of traditional budget information.

The declining exposure expectation is also based on the argument that support and use of a tool such as PART follows political party lines. During PART's initial years the government was unified under a Republican president. However, beginning in 2007, the Democrats were in the majority in both chambers of Congress. Since the majority party drives the congressional agenda, we expect both a decrease in the number of hearings where PART is mentioned and a decrease in the number of members mentioning PART. In addition, the Bush Administration was approaching its end, which it can be argued, further reduced the interest in PART. Strong leadership is important in the implementation of resultsoriented reforms (Dull, 2006). As indicated by Posner (2007), agencies tend to reduce their commitment 
to an executive tool as they began preparing for a presidential transition. This might translate into a reduced willingness to incorporate and reference PART information as part of congressional justification materials.

It is also possible that legislators, on both sides of the aisle, had begun distancing themselves from PART because of the Bush Administration's decline in public approval ratings (Gallup, 2011). By 2006 it had become obvious that President had pushed the envelope of presidential power further than any other contemporary President. This was also the "cursed” period, the mid-term of the second term, when typically the legislative majority loses to the minority (Shogan, 2006). However, the President's unpopularity was not always the case. President Bush was the first Republican president in 40 years who had a majority in both chambers of congress, albeit a slim one. The attacks on September 11 re-focused his agenda on the war on terrorism and his approval ratings soared (Ornstein \& Fortier, 2002). As explained by Ornstein \& Fortier (2002),

The nation united, and bipartisanship became the watchword in the Congress. Most partisan initiatives were dropped and differences muted as the Congress focused on providing relief to victims, affected industries, the military, and the reform of security and transportation procedures. Bush’s approval ratings reached above 90\% (p. 50).

However, legislators have limited incentive to support the policies and innovations of an outgoing president. In addition, the shift from a unified government to a Democrat-led congress in 2007 is argued to adversely affect legislators' use of PART and sentiment towards it.

\section{Descriptive Statistics}

A combined total of 6,967 hearing reports were identified as published for both chambers during 2003 through 2008. A total of 454 of these hearings included PART-referenced statements by legislators, which represents $6.52 \%$ of the total number of published reports (U.S. GPO, Congressional Hearings). As indicated by Figure 3, the highest number of published hearings that included references to PART occurred in 2005 (for both chambers).

When measured in proportion to published hearings the analysis indicates an increase in the proportion of hearings in which PART was referenced for all stakeholders, between the 108th and the 109th Congress for both chambers, but a decline in references between the 109th and the 110th Congress. 
Figure 3: Congressional Hearings that Included PART References

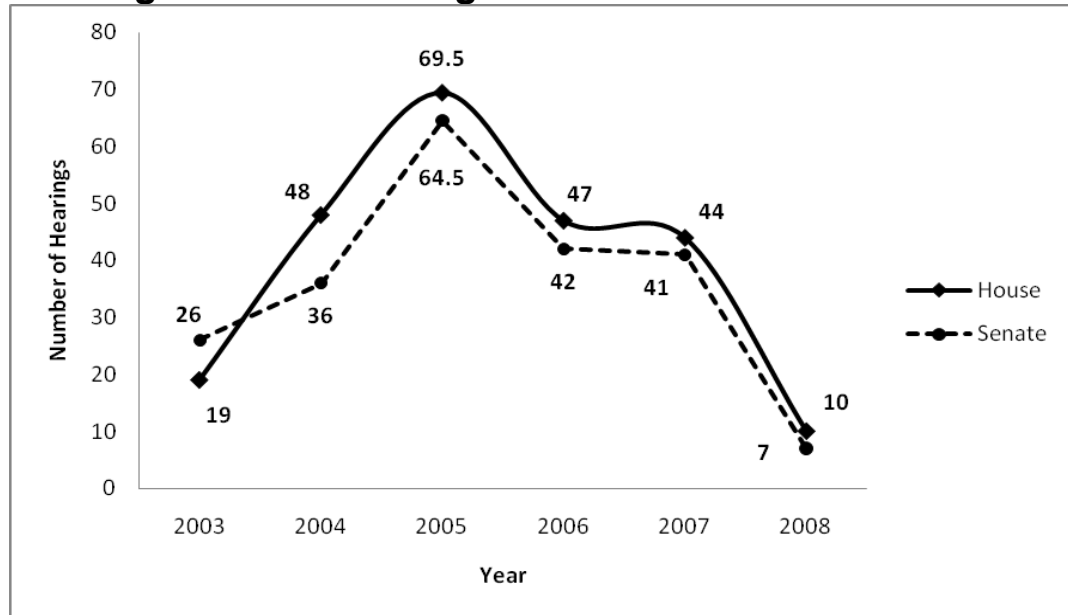

As indicated by Table 6, the proportion of hearings in which PART was referenced increased from $6.08 \%$ to $8.85 \%$ between the $108^{\text {th }}$ and the $109^{\text {th }}$ Congress and declined from $8.85 \%$ to $4.39 \%$ between the $109^{\text {th }}$ and the $110^{\text {th }}$ Congress. Legislator references to PART increased from $1.79 \%$ to $3.77 \%$ of all hearings between the $108^{\text {th }}$ and $109^{\text {th }}$ Congress and then decreased from $3.77 \%$ to $2.45 \%$ between the $109^{\text {th }}$ and the $110^{\text {th }}$ Congress. An analysis by chamber offers similar results.

Table 6: PART-Referenced Hearings Compared to Total Hearings 2003-2008

\begin{tabular}{|c|c|c|c|c|c|c|c|}
\hline & & \multicolumn{2}{|c|}{ House } & \multicolumn{2}{|c|}{ Senate } & \multicolumn{2}{|c|}{ Totals } \\
\hline \multirow{7}{*}{ 108th } & \multirow[b]{2}{*}{ All hearings } & \multicolumn{2}{|c|}{ count percent } & \multicolumn{2}{|c|}{ count percent } & \multirow{2}{*}{$\begin{array}{c}\text { count } \\
2121\end{array}$} & \multirow[t]{2}{*}{ percent } \\
\hline & & 1226 & & 895 & & & \\
\hline & Hearings w/PART references: & 67 & & 62 & & 129 & \\
\hline & Percentage to all hearings & & $5.46 \%$ & & $6.93 \%$ & & $6.08 \%$ \\
\hline & Hearings w/congressional PART refs: & 13 & & 25 & & 38 & \\
\hline & Percentage to PART referenced hearings & & $19.40 \%$ & & $40.32 \%$ & & $29.46 \%$ \\
\hline & Percentage to all hearings & & $1.06 \%$ & & $2.79 \%$ & & $1.79 \%$ \\
\hline 109th & All hearings & 1449 & & 1072 & & 2521 & \\
\hline & Hearings w/PART references: & $116.5^{*}$ & & $106.5^{*}$ & & 223 & \\
\hline & Percentage to all hearings & & $8.04 \%$ & & $9.93 \%$ & & $8.85 \%$ \\
\hline & Hearings w/congressional PART refs: & 45 & & 50 & & 95 & \\
\hline & Percentage to PART referenced & & $38.63 \%$ & & $46.95 \%$ & & $42.60 \%$ \\
\hline & Percentage to all hearings & & $3.11 \%$ & & $4.66 \%$ & & $3.77 \%$ \\
\hline $110^{\text {th }}$ & All hearings & 1553 & & 772 & & 2325 & \\
\hline & Hearings w/PART references: & 54 & & 48 & & 102 & \\
\hline & Percentage to all hearings & & $3.48 \%$ & & $6.22 \%$ & & $4.39 \%$ \\
\hline & Hearings w/congressional PART refs: & 25 & & 32 & & 57 & \\
\hline & Percentage to PART referenced & & $46.30 \%$ & & $66.67 \%$ & & $55.88 \%$ \\
\hline & Percentage to all hearings & & $1.61 \%$ & & $4.15 \%$ & & $2.45 \%$ \\
\hline
\end{tabular}

*Joint hearing 
Focusing on hearings where legislators reference PART, the percentage of hearings increases with a total of $29.46 \%$ to $42.6 \%$ of hearings between the 108th and 109th Congresses and from $42.6 \%$ to $55.88 \%$ from the 109th to the 110th Congress, which suggest that legislators over time took a more direct role in discussing or drawing attention to PART This trend holds true across chambers.

Figure 4 provides a more detailed illustration of congressional hearing participants who mentioned PART in relation to other participants, including federal agencies, OMB, and other stakeholders. This figure illustrates the number of participants in each group divided by the total number of participants for each year. Figure 4 indicates an overall decline in congressional PART references in relation to the other participants beginning in 2006. References to PART declined in conjunction with a decrease in the number of PART-referenced hearings for that year after a peak in 2005. The period of unified Republican government ended with the start of 2007 with the Democrats gaining a majority in both chambers of Congress. This shift in power is a likely explanatory factor of the decline. It is important to recall that the majority party has greater control over committee hearings and in the selection of witnesses.

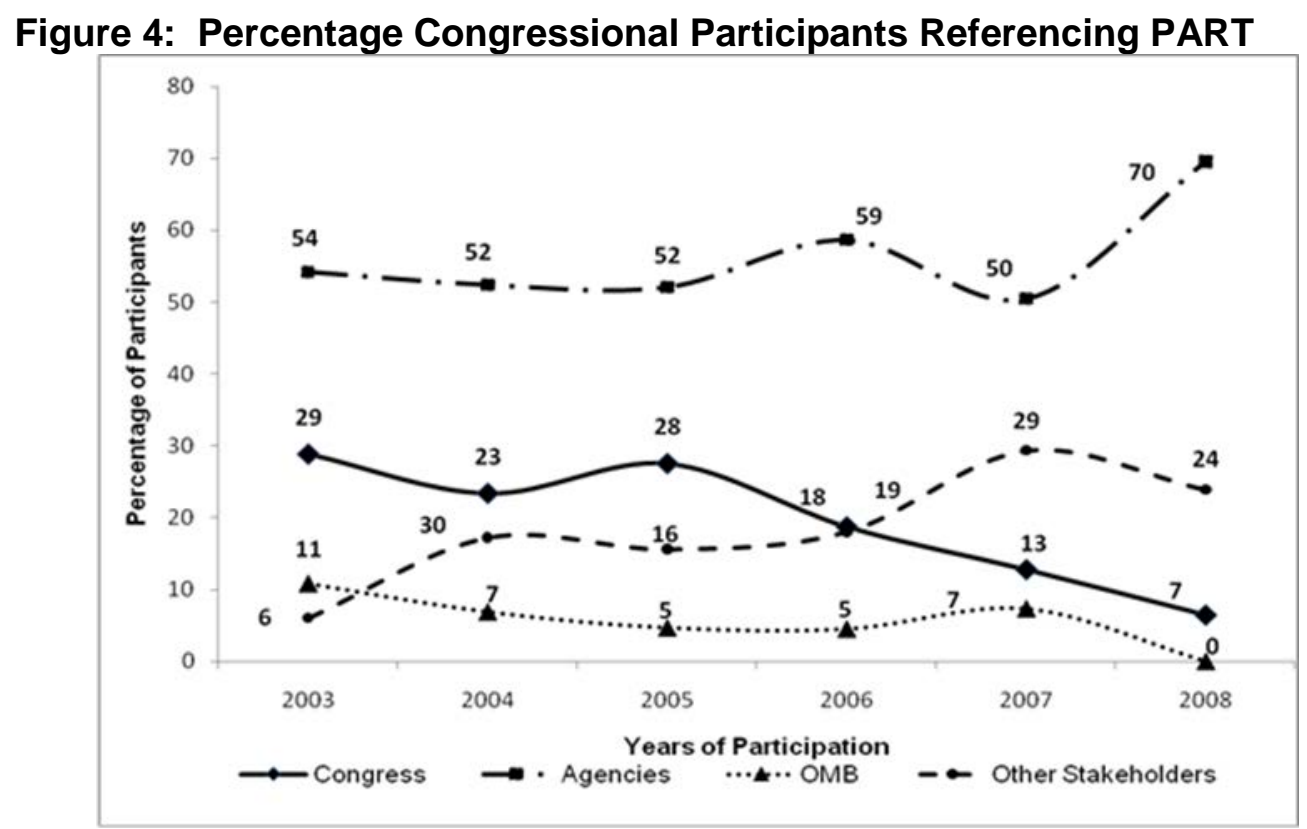

Figure 4 also illustrates that federal agencies increasingly have been the source of PART references, which is consistent with the increase in PARTed programs and the requirement imposed on agencies to include PART scores in their congressional justification materials. The data also demonstrates the failure of PART to engage the interest of other stakeholders (i.e. interest groups). 
Stakeholders who testified about budget or program management reform were primarily from think tanks, consulting firms, and academia—all were performance management advocates. Stakeholders from think tanks were overwhelming conservative such as The Heritage Foundation, Citizens Against Government Waste, and Citizens for a Sound Economy (deregulation advocates). Although it is a stretch to state that PART generated subsystem activity, we can state that groups interested in fiscal conservatism, performance management, and government waste embraced PART within their cause.

\section{PART and Party Affiliation Across Chambers}

The second step of the analysis was to identify references to PART across party affiliation and across chamber. This is important in determining whether the decline in the proportion of legislators that reference PART in relation to other participants is a result of political affiliation (Table 7). The expectation is that the President's agenda receives greater support from his own party, indicated by members speaking about PART in a positive tone across committees, especially during the periods of unified government up to 2007. With the Democrats in the majority in both chambers of Congress beginning in 2007, the expectation is a decrease in the number of hearings where PART is mentioned, a decrease in the number of members mentioning PART, and an increase in negative sentiment regarding this tool.

A breakdown of the data by party affiliation indicates similarities in sentiment across both chambers. Table 7 shows the number of different (i.e., unique) members who participated in hearings where PART was referenced for each year. A total of 30 different Republicans and 27 different Democrats in the House and 29 Republicans and 28 Democrats in the Senate referenced PART during the period of analysis. This similarity between parties is unexpected, because the President's party is expected to support the President's agenda, especially during periods of unified government. This support should be greater than normal considering the infrequency of a unified government under Republican control.

An issue related to the failure of PART to gain a foothold in Congress may be the decline in the strength and cohesiveness of the party system. No longer can a few key legislators direct the legislative pack. As stated by Dean Rusk in 1976, "In the 1950s and 1960s we handled sensitive foreign affairs policy questions with the Congress by dealing with the 'whales — Rayburn, Vinson, men like that. They could make commitments. Now it is as if were dealing with 535 minnows in a bucket” (Kernell, 1997, p. 49). From 2003 through 2007 a unified government failed to adopt PART. In addition, two unsuccessful 
efforts were made to codify the PART-like review of government programs every five years in the Program Assessment and Results Act (PARA).

Table 7: PART-Referenced Hearing Participation by Political Party

\begin{tabular}{|r|cc|cc|}
\cline { 2 - 5 } \multicolumn{1}{c|}{} & \multicolumn{2}{c|}{ House } & \multicolumn{2}{c|}{ Senate } \\
\cline { 2 - 5 } 2003 & Democrats & Republicans & 5 & Republicans \\
2004 & 3 & 4 & 2 & 5 \\
2005 & 7 & 10 & 10 & 12 \\
2006 & 8 & 8 & 6 & 4 \\
2007 & 6 & 7 & 3 & 2 \\
2008 & 3 & 1 & 2 & 1 \\
\hline \multirow{2}{*}{ Totals } & 0 & 0 & $\mathbf{2 8}$ & $\mathbf{2 9}$ \\
\cline { 2 - 5 } & \multicolumn{2}{|c|}{$\mathbf{2 7}$ *Total membership of each chamber includes 435 House members and 100 Senators. } \\
\end{tabular}

\section{Across Committees}

The third and final step in this analysis is to determine how diversified PART is across committees, which is important for purposes of determining whether congressional exposure was broadening. Exposure means that the legislator was either noted as present in the hearing report or, if attendance information was not provided, spoke at the hearing. However, presence may not be a true measure of PART exposure, because members are called away for votes and may miss PART references. Documented presence of legislators in committee hearings where PART was mentioned served as a proxy measure for exposure to PART. The higher concentration of reports among House committees was found in the Appropriations, the Government Reform, and the Resources committees. Senate data display similar activity with the most PART reports occurring in the Appropriations and Energy and Natural Resources committees. Because PART is a budgeting tool, one would expect to see a greater involvement with PART in the Appropriations committees.

Further analysis of PART exposure across committees demonstrates that $86 \%$ of all Senators serving during this period may have been exposed to PART with an average of eight hearings per Senator. Greater exposure is expected in the Senate because each Senator serves on more committees than do House members. Exposure percentage in the House is 66\% with an average of two hearings per Representative. Of these percentages, those legislators who discussed PART or PART scores were 31\% and $7 \%$ of the Senate and House, respectively. In the Senate, a lack of exposure to PART appears not to have been a factor in PART use. However, the moderate exposure in the House with low participation could explain why PART was not embraced by this chamber. 
A few legislators engaged in entrepreneurial activity regarding PART. Mayhew (1974) stated that some committees provide good platforms for position-taking, for gaining benefits, and for dividing the work in ways that gain members visibility and claim credit. Representative Todd Platts (R, Pennsylvania) sponsored the Program Assessment and Results Act (PARA); a legislative effort introduced in the House in 2004 (H.R. 3826) and again in 2005 (H.R. 185) that required a PART-like review of government programs every five years. Former Senator Wayne Allard (R, Colorado) whose comments spanned three Congresses $\left(108^{\text {th }}\right.$ through $\left.110^{\text {th }}\right)$ and three committees (Banking [2004-2005], Budget [2005-2007], and Appropriations [2007]) warned agency witnesses to always have their PART scores when they testified. Senator Tom Coburn (R, Oklahoma) was a driver of PART discussion during his Chairmanship of a Government Reform subcommittee. PART was a good fit within each Senator's overall agenda of fiscal conservatism and government reform. Wawro's (2000) study of House members found that increased entrepreneurship helped Democratic members get promoted in committees and in the party; however, this did not hold true for Republicans. Wawro determined that advancement for House Republicans increased with their distance from the median voter in NOMINATE scores. He believed this difference was due to the frequent minority status of the Republican Party, as leadership positions are less important for the minority.

\section{Analysis of PART Sentiment}

Analysis of PART sentiment demonstrated that $67 \%$ of comments were neutral in tone and $23 \%$ positive. Only $10 \%$ of the comments were negative. Although twice as many members were positive than negative regarding PART, the majority was neutral. This may suggest that a large portion of those legislators that were exposed to PART were indifferent to it as a tool for congressional decision-making.

The coded data were then analyzed to determine if PART sentiment is associated with political party affiliation. When segregated by party affiliation, both parties had primarily neutral views with $75 \%$ of all PART-referenced comments by Democrats coded as neutral and 64\% of Republicans. As expected, Republicans had more positive comments (33\%) as compared to Democrats (8\%) and Democrats had more negative comments (17\%) than Republicans (3\%).

Most of the discussions about PART were within the context of executive use. However, legislators also discussed PART within the context of congressional use. PART comments made by legislators can be divided into two categories, PART as methodology and PART as allocation (applied to specific programs). Some legislators found PART appealing due to its ability to measure effectiveness of 
federal programs; make agencies more accountable; add transparency; provide good data for managers;

and ensure that the programs worked as intended. A positive example:

Mr. Chairman, on all these hearings that we have where we have the Secretaries show up who are in charge of the various Departments, I'm making an effort to sort of sensitize everybody to how important the PART Program is, because, as policymakers here on the congressional side, budget and appropriators, it's shedding information. And we get particularly concerned, I think, when we see something that's rated as ineffective. And if we - even worse yet, in my mind, is, we see an agency that is not demonstrating results, which, to me, lacks - shows a lack of effort. (Wayne Allard [R, CO], Appropriations Committee) (U.S. Senate, 2007, p. 125).

Neutral legislators were interested in understanding how PART worked; expressed concern about ensuring credibility; and were concerned about the transparency of the review process. However, the majority of neutral comments questioned the PART scores of specific programs with which legislators were familiar. A neutral example:

As I've stated over and over again and, of course, also in many hearings, successful management initiatives require a sustained and concerted effort, along with mutual cooperation and understanding, between OMB and the Federal agencies. Furthermore, we must ensure that political ideology does not adversely impact the production of reliable and credible information or jeopardize the confidence of all stakeholders in the results. While I recognize that PART is a tool for the executive branch to better analyze Federal programs and outcomes, it must be used in concert with other performance-based assessments in order to be useful to others in both the agency and congressional arenas (Edolphus Towns [D, NY], Government Reform Committee)(U.S House of Representatives, 2004, p. 5).

Legislators who viewed PART negatively did so out of concern that it would be used as a political tool to enforce the President's agenda. However, the primary concern of these negative-leaning legislators was the impact that PART scores would have on programs that were valued by their constituents. Legislators also worried that the goals documented in PART reviews would take precedence over statutory goals. A negative example:

... we need to be certain that the Program Assessment Rating Tool or whatever mechanism we use to make these evaluations is itself effective. To be effective, a program like the Program Assessment Rating Tool must be totally separated from politics and ideology. It must also be closely coordinated with existing mechanisms agencies and Congress use to align budgets with program goals and outcomes, such as the Government Performance and Results Act. And perhaps most importantly, we also need to make sure that a program's intended beneficiaries outside of Washington have a say before an evaluation is completed. While I'm keeping an open mind on this issue, I've some evidence that the Rating Tool might fail all three of these tests. (Thomas Carper [D, DE], Homeland Security Committee) (U.S. Senate, 2005d, p. 22). 
Figure 5 captures the tone of legislators by political party over time. It is interesting to note that a Negative Republican views decreased; some neutral Republican views shifted to positive. Positive Democratic views decreased, as did negative Democratic views. Some neutral Democratic views shifted to negative views.

Figure 5: Tone of Legislators Regarding PART

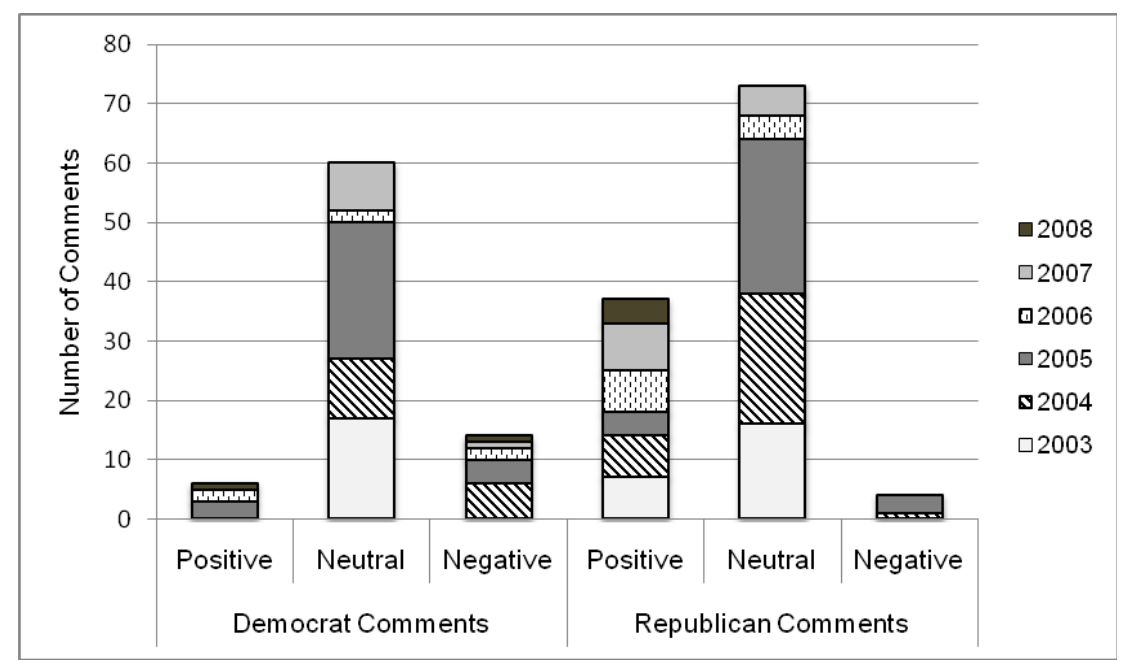

Trending these values (Figure 6) confirms the greatest polarization in PART opinion occurred in 2004 followed by a year of neutrality in 2005. This tone trend could be related to the increase in exposure to, and the growing knowledge of, PART. Initial reaction to PART could have prompted members to react along party lines. Greater knowledge and exposure to the tool may have tempered initial responses. Comments by congressional Democrats stabilized as slightly negative after 2005. Republican comments have become less positive since its peak in 2007. As noted earlier, this may be due to the influence of a Democratic majority beginning in 2007 or the growing disillusion with, and declining popularity of, the sitting President.

In addition, across the period of study, OMB fielded questions from legislators concerned about the ideological basis of PART use, which suggests that many members of Congress did not buy the tale of neutrality advocated by OMB. It is important to remember that prior to the Budgeting and Accounting Act of 1921 each federal agency requested funding directly from the Appropriations Committees. The Act established the executive budget, requiring the President to make agency funding requests. Thus, the legislature formalized the presidential agenda into the budget process. As stated by Fenno (1968),

... no budgetary reform is neutral. Or conversely, every change in the budgetary process has an effect on the distribution of power within the political system, on who wins and 
who loses conflicts over policy, on whose preferences are granted legitimacy, on who gets what in American society (p. 175).

Figure 6: Net Tone of Legislators Regarding PART

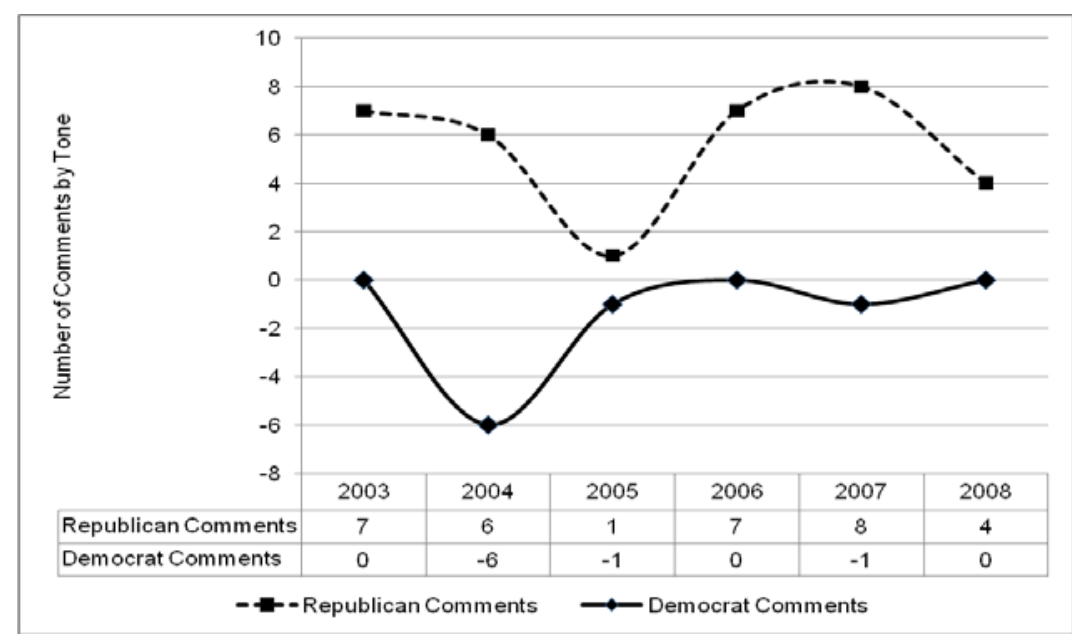

*Number of positive-tone comments minus the number of negative-tone comments

Using this frame, budget reform efforts can be viewed as a way of centralizing control. Fenno (1968) states further, "Congressmen are well aware that budgetary reform begun in the executive is not only not neutral but potentially quite detrimental to them” (p. 176).

\section{Findings and Discussion}

Several findings resulted from the analyses. First, the lack of interest in PART was not due to the lack of exposure to the tool. The analysis indicates that congressional exposure to PART peaked in both chambers in 2005 and 2006. This may be a result of legislators distancing themselves from PART during President Bush's second term as his public approval declined and Republicans lost ground in Congress. Second, the results echo previous findings, which suggest that congressional PART exposure was relatively moderate during the six years the tool was utilized. Third, in contrast to expectations, the analysis indicated that the proportion of legislators that were a source of PART references increased over time in relation to other actors. This suggests that legislators may have gotten more actively and directly involved in PART discussions. Finally, the results indicate that legislators' sentiment toward PART became slightly more positive over time and that the greatest polarization in PART opinion occurred in 2004. Support for PART also became less associated with party affiliation. It is likely that initial reaction to PART prompted legislators to react along party lines and that greater knowledge and exposure to the tool tempered initial responses. 
These findings are important for three reasons. First, they contribute to a more comprehensive understanding of the extent to which the separation of powers interferes with the implementation of budget reforms. As stated previously, only a very limited number of studies have systematically examined this relationship (Blanchard, 2008).

Second, the findings exemplify the consequences of differences in the challenges faced by the government that seek to adopt and implement government-wide administrative tools. In contrast to the U.S. form of government, most parliamentary systems are not challenged by a separation of power system.

Finally, the findings add to existing explanations of why another budget reform was not sustained. The lack of interest in PART in the legislative branch, including the president's own party, appears to have undercut PART's sustainability. Nevertheless, the fact that legislators became more positive toward the tool as time proceeded offers some hope for the prospect of gaining congressional support for a government-wide budgeting tool originating within the executive branch.

\section{Conclusion}

With the growing deficit and other economic woes it is likely that no legislator found it beneficial to expend political capital, and valuable time, to a reform effort that applies only to the discretionary part of the federal budget. The issues discussed in congressional committees are numerous; they cover a large range of topics and are addressed in a very short period of time. Members have agendas based on constituent, personal, and special interests; areas of experience and expertise; and reciprocity. They must strategically pick their battles and direct their interests due to constraints, such as time and resources. Cox and Terry (2008) found significant and large differences in productivity between committee leaders and committee members; between majority and minority members; and a larger positive effect regarding seniority and minority status. Cox and Terry (2008) contended that, with experience, members become more efficient at trade, developing a kind of capital — they simply have more benefits to distribute. This is important because committee members and leadership determine which bills reach the floor (and the greater agenda) and therefore are critical to making changes or maintaining the status quo. These observations confirm the incremental nature of congressional change.

Underlying the acceptance of reforms is the separation of powers, which structures the relationship between Congress and the president in such a way that there is no incentive for legislators to adopt executive reforms. PART demonstrated no clear benefit to Congress. Had PART been viewed as a 
successful tool for the executive, or created an informational asymmetry to the disadvantage of Congress, it may have gained greater interest by legislators. At best it enabled some legislators to speak more positively of their favored programs. However, the president's failure to seek congressional buy-in while developing PART and suspicion of his motives about using PART as an ideological tool discouraged Congress from embracing PART.

The next chapter provides insight into why PART failed to gain a foothold in Congress. 


\section{Chapter 4}

\section{Congressional Use of PART: Legislative Characteristics}

"A saving grace of the American system of representative government is that default of political choice near the top is accompanied by the 'sideways' insertion of politics." Richard Rose, (1976, p. 167)

The previous chapter offered insight into the extent the U.S. separation of powers structure interferes with the implementation of government-wide performance measurement systems at the federal level by examining the congressional resistance to PART. This chapter determines what characteristics are likely to influence legislators' sentiment toward PART; specifically, the influence that individual legislators' personal experiences and ideology had on their acceptance or resistance to PART ${ }^{1}$. The characteristics include legislators' ideology; level of business experience; amount of campaign financing they received from political action committees (PACs); years spent in Congress; seniority in Congress; and the chamber in which they are a member. To explore these relationships, a linear binary regression model was developed that regressed measures of these characteristics against measures of legislators' general attitude towards PART.

The results of the analysis indicate that legislators with higher levels of business experience generally were more supportive of PART and that the amount of campaign contributions received by legislators from PACs was negatively related to PART support. The study also provides insights into the overall exposure and sentiment toward PART, indicating that only a small proportion of legislators expressed clearly positive or negative opinions towards PART, despite widespread legislative exposure to the tool.

The findings of the research are important for several reasons. First, they provide a more comprehensive understanding of the congressional reaction to PART. Only a very limited number of studies have systematically examined the relationship between PART and congressional decision-making (Blanchard, 2008). Blanchard (2008) examined the impact of PART assessments on congressional budget allocations. Based on a statistical analysis of 680 programs assessed from 2003 through 2007, the study illustrated that PART ratings had a statistically significant impact on budget outcomes. Specifically, the study demonstrated that higher performing programs were rewarded with funding increases, both by the OMB and Congress, and that programs that are not performing were penalized by funding reductions.

\footnotetext{
${ }^{1}$ Content in this chapter previously published in Stalebrink, O. J. \& Frisco, V. (2011). PART in Retrospect: An Examination of Legislators’ Attitudes Toward PART. Public Budgeting \& Finance, 31(2), 1-21.
} 
Second, the findings draw attention to challenges associated with adopting sustainable performance-based management systems at the U.S. federal level of government. The findings are consistent with the notion that these challenges arise in part from the separation of powers structure, which complicates agreement on program and agency objectives, and feeds a common perception that executive reform initiatives are politicized and created for purposes of shifting policy control away from Congress towards the Presidency.

Third, the findings provide insight into the inherent difficulties that budget reform faces. Congress, and the President, has been modifying the budgeting process for more than 100 years yet whether implementing major reform or whittling away at the edges through incremental process changes, federal budgeting grows increasingly contentious, unreasonably protracted, and impedes the ability to govern.

Finally, the findings are important from a comparative perspective. They exemplify the consequences of differences in the challenges faced by the American reform model and the Westminster model on the relative speed by which the reforms were adopted and implemented. In contrast to the American model, the Westminster reform movement was not challenged by a separation of power system. The concentration of power in parliamentary forms of government, such as Great Britain and New Zealand, facilitated reform efforts by simplifying the process of agreeing on program goals and agency objectives. This concentration of power is likely an important explanation to why the implementation of the Westminster reforms was speedier and less incremental, compared to the U.S. reforms.

Data on the impact of PART assessments on congressional appropriations suggests that Congress largely ignored PART. Studies examining congressional PART use have been either inconclusive or indicated a very weak (U.S. GAO, 2005, 2008; Norcross and McKenzie, 2006; Blanchard 2008). Joyce (2008) summarized the congressional experience with PART by stating that “... Congress has either ignored the PART or has been openly hostile to it” (No Page).

An important goal of this research is to add insight into why PART failed to gain a foothold in Congress. The existing literature offers at least four explanations. The first is grounded in the institutional structure of the U.S. federal system of government. This structure has at least two components that appear to limit the prospect of gaining congressional buy-in for executive initiatives, such as PART. The first is the separation of powers between the Congress and the Presidency. This separation gives rise to a contest over the control over the power of the purse in which each branch develops its own budget 
process, each with its own budget staff and operating rules, for purposes of gaining an advantage in the budget process (Schick, 2000). As explained by Moe (1985), presidents tend to “politicize” administrative and analytical tools as a means of gaining policy control. Using this logic, it can be argued that Congress either opposes or ignores executive tools such as PART on the basis that they hold potential for placing Congress at a disadvantage in the budget process. Ho (2009) concluded that legislators viewed PART “... as a political tool by the White House to take over the policymaking authority of Congress” (p. 12). Gilmour and Lewis (2006a) drew a similar conclusion noting that a major challenge to the implementation of PART was “... to get appropriators to buy into the idea that that PART is a useful decision-making tool rather than 'a cover for the Bush Administration’s own policy preferences ”” (Gilmour and Lewis, 2006a).

Congress' perception of PART as a political tool was likely augmented by systematic efforts undertaken by the Bush Administration to expand its power. A good example of this deliberate expansion of executive power is exemplified by the President's frequent use of signing statements to reduce the effectiveness of legislation (Cooper, 2005; Savage, 2006).

A second institutional component of the federal system that appears to limit the prospect of gaining congressional buy-in for executive initiatives such as PART is the lack of a link between program performance and the electoral benefits sought by legislators. These benefits are driven by local demands imposed on legislators by their constituents, especially in the case of House members who are elected by a constituency from a specific geographical area within a state. As explained by Ho (2009), congressional delegates' perspective on performance are shaped by voter expectations in their drive to be re-elected by showing “... what legislation they have passed on issues that are important to their voters (the 'output' measures of politicians), and what benefits they have delivered to their districts (the 'outcome' measures)” (p. 6). It can be argued that a national performance framework such as PART provides little value in rallying support at the local level. Therefore, legislators have few incentives to request and use information about the performance of programs (Joyce, 2007). There is also a risk that the information generated by the framework raises questions about the performance of individual programs upon which a legislator's local popularity depends. Under such circumstances, the legislator has an incentive to oppose a national performance framework.

The second explanation is grounded in the manner by which PART was implemented. Two implementation-related factors have been cited as having contributed to PART's failure to gain a foothold in Congress. The most frequently cited is the Bush Administration's failure to involve Congress during 
the development and implementation of PART (U.S. GAO, 2005, 2008). Such involvement is critical for several reasons. Congressional input is necessary to assure that the tool is perceived as relevant and credible by both branches and eliminates informational asymmetries. Development without congressional involvement creates a perception among legislators that the tool is created for purposes of serving the needs of the President at the expense of Congress. The involvement is also politically important, because it provides legislators with an opportunity to reap the symbolic benefits of implementing performance reform.

The importance of involving Congress in the development and implementation of an executive performance initiative is evident from the experience of previous reforms aimed at integrating information about the performance of federal programs into the federal budget process. The consensus is that these initiatives failed partly because they were not perceived as relevant by budget decision-makers in Congress (U.S. GAO, 1997; Posner and Fantone, 2007).

A second implementation-related factor that appears to have influenced Congress' sentiment toward PART was the Bush Administration's attempt to systematically impose PART information on Congress. This was achieved by requiring agencies to include PART assessments in their budget requests; a requirement that can be traced back to a memorandum by former OMB Director Mitchell Daniels. The memorandum is dated January 14, 2003 and reads,

To ensure the best available information is included in program justifications sent to the Congress, summaries of completed PARTs and their relation to the Administration's proposals should now be incorporated into the rationale for the budget request for all pertinent activities. In particular, they should be incorporated into your agency's Congressional justification materials. Performance information should enhance the Congressional Justifications without overwhelming the reader. And, this addition to the Congressional Justification will also provide agency performance data in a single document to the Congress (Daniels, 2003, p. 1).

The third explanation is based on critiques against the design of the PART framework. The Obama Administration has identified three such critiques that it sought to rectify in the development of its own performance framework (U.S. OMB, 2009, p. 9). These include the lack of transparency in the rating process; a focus overly concerned with the rating process and not concerned enough with explaining performance; and it ignored assessment of cross-program and cross-agency goals. In addition, the Obama Administration also planned to rectify PART's failure to stimulate the actual use of performance measures beyond the OMB. Several academics have identified tool-specific elements that have contributed to this latter challenge. Some of these include, the failure of PART to recognize program 
diversity (i.e., a “one-size-fits-all” ideology) (Radin, 2006); its focus on efficiency and bottom line information in a context where programs often have multiple and conflicting objectives (Radin, 2006); penalizes programs that depend on intergovernmental collaboration (Stalebrink, 2009); and the disconnect between PART and GPRA frameworks (Gueorguieva, et. al., 2009).

A final explanation for why Congress did not embrace PART is grounded in the congressional make-up that surrounded PART. Lee, et. al. (2008) identified several legislative characteristics that may have played a role in Congress' receptiveness to PART including, the level of fragmentation within and across chambers, political party leadership, and committee structures. There is a large body of literature on congressional behavior devoted to demonstrating the primacy of electoral, partisan, or policy influences (Mayhew, 1974; Fenno, 1978, 1994; Arnold, 1990).

This research explores the role that legislators' personal experiences and ideology played in the congressional reaction to PART. Six different factors are assessed. The first factor is legislators' ideology. Legislators that hold a conservative ideology are expected to have been more supportive of PART than legislators that hold a more liberal ideology. This expectation is grounded in the notion that performanceoriented frameworks such as PART are more consistent with the goals of a conservative ideology by emphasizing transparency, accountability, efficiency, and effectiveness, which often is characterized by a reduction in the size of government, deficit reduction, disdain for taxation, and a balanced budget. In addition, conservative stakeholders played significant roles in the development of PART.

The second factor explored is legislators' level of business experience. Performance measurement is commonly used in business to manage projects, people, and budgets. Having gained first-hand experience with these types of tools, legislators with business experience can be argued to have found a familiar tool in PART; as such, they will prefer the norms with which they are familiar. The inclusion of this characteristic is important because an increasing number of legislators have business experience, which is partly due to the growing prominence of the pro-business Republican Party (Davidson and Oleszek, 2004). Furthermore, in their exploration of the importance of professional business experience of House members, Witko and Friedman (2008) found that business experience significantly influenced behavior. Specifically, they found that legislators with business experience participate in more probusiness voting and have closer relationships with business interests. In addition, it is common for government to implement budget reforms that have originated in the business community; PPBS and the Ford Motor Company, for example. 
The third factor explored is the amount of campaign contributions that legislators receive from PACs. PACs give money to politicians to gain access and control in order to further their agenda. This currying of favor can be argued to be the antithesis to a tool like PART, which was promoted as a neutral tool that would seek to objectively quantify the success of programs in the allocation of funding, as well as increase transparency and accountability of the appropriations process. As such, it can be argued that legislators that receive a relatively large amount of PAC contributions are more likely to voice opposition against PART. However, it is important to note that this influence might partly be offset by legislators' perception of PART as a political tool. Given the latter influence, we expect the relationship between PAC contributions and PART opposition is likely weak, albeit positive.

The fourth factor is legislators' seniority in Congress (defined as committee chairmanship and whether the legislator is a member of one of the power committees). This variable explores the possibility that the more senior legislators will likely be hostile to PART. Joyce (2008) identified this as the primary explanation to Congress' hostility or indifference to PART, writing that congressional hostility existed ... primarily because there are many powerful members of Congress who see the attention to performance as a potential threat to their ability to control the allocation of resources, and particularly to direct those resources based on constituent concerns (that is, largely based on WHERE the inputs flow, rather than WHAT the program has accomplished) (No Page).

The fifth factor explored is congressional chamber. This factor assesses the different perspectives and roles held by members of the House and Senate. Here, however, the theoretical relationship is more ambiguous. Members of the House Appropriations Committee have traditionally viewed themselves as guardians of the public purse and have regarded members of the Senate Appropriations committee as “frivolous spendthrifts of the public purse” (Wildavsky \& Caiden, 2004, pp. 56-57). Wildavsky and Caiden explained:

[House Appropriations] Committee members are expected to cast a skeptical eye on the blandishment of a bureaucracy ever anxious to increase its dominion by increasing its appropriations. The role of guardianship is reinforced by the house leadership, which deliberately chooses committee members from safe districts who can therefore afford to say ‘no' (2004, p. 56).

Given that PART is promoted as a tool to ensure accountability and transparency, it can be argued that PART is consistent with the perspectives and roles of the House. Moreover, the constituency for members of the House is more localized than for Senators. It can be argued that the lack of a link between program performance and the electoral benefits sought by legislators is likely larger for House 
members. House members are more frequently exposed to pressure to face their constituencies, compared to their counterparts in Senate, because they face re-election every two years rather than every six. For these reasons, it may also be argued that members of the Senate are less prone to oppose PART, compared to members of the House.

The final factor explored is time served in Congress. A common view of the American political system is that over time elected officials are "corrupted” by the system and start favoring the politics and “folkways” of Congress. As noted by Matthews (1959) politicians with former non-political careers learn the politics and folkways of Congress over time. Using this logic, it can be argued that the number of years served would be positively related to PART opposition, given that PART challenged the conventional way Congress appropriates funds. If effective, PART could be viewed as a tool that might constrain legislative discretion and open the process to further scrutiny, which could raise questions (and public concerns) about fairness and the allocative efficiency of public spending decisions. It could also constrain reciprocity, negatively impacting how Congress gets work done. Given this, legislators that have served longer in Congress are more likely to oppose PART.

\section{Research Approach}

A binary linear multiple regression was used to examine the relationship between the proposed explanatory factors and legislators' attitude towards PART. The first step in the model building process was to develop a dependent variable (i.e., legislators' general attitude towards PART) that captures differences in legislators' sentiment towards PART. This was achieved by collecting and reviewing PART-related comments made by legislators, published in congressional hearing reports between 2003 through 2008. The committee reports were gathered from the GPO Access and the ProQuest Congressional databases using the search criteria of "program assessment rating tool" and "PART.” A combined total of 6,967 hearing reports were identified as published for both chambers during this time period.

It should be noted that written testimony included in committee reports, as well as questions submitted by legislators, was included as demonstration of PART discussions even if this content was not verbally presented during the hearing.

Following the identification of the comments, the content of each comment was carefully reviewed and coded in terms of individual legislators' sentiment toward PART. The coding was based on three basic sentiments: positive, negative, or neither (referred to as "neutral” in the analysis). When 
individual legislators had made more than one comment about PART, an overall opinion was issued to prevent double counting. Furthermore, if the statement(s) did not clearly indicate a positive or negative sentiment or if the statement(s) were arbitrary in terms of the legislator's sentiment towards PART, the coder was instructed to code it as neutral. To allow for checks of inter-rater reliability the coding was conducted by two different coders. A total of $92 \%$ of the responses were similar for the two independent coders.

Given that the objective of this research is to explore the role of factors hypothesized to influence legislators' attitudes towards PART, the statistical analyses focused on the responses that were coded as positive or negative. Using a database of all 653 legislators that served in Congress 2003-2008, a binary dependent variable was developed based on the coded results. This variable coded legislators with a negative sentiment towards PART with a 0 and legislators with a positive sentiment with a 1 .

The second part of the model building process developed measures for the explanatory variables, along with control variables. Proxies for six independent variables were developed for inclusion in the model. Table 8 outlines the measures and the accompanying data sources for each. Table 8 also includes four control variables. These include legislators' exposure to PART, party affiliation, membership on an appropriations committee, as well as a control for divided government.

The first control variable — exposure to PART—controls for the possibility that familiarity and knowledge with PART strengthens legislators' attitudes towards PART in either direction. It was measured by the presence of each legislator at hearings where PART was mentioned. Of the more than 650 legislators that served in Congress during the period of study $86 \%$ were exposed to PART.

The second control variable — political party affiliation—controls for the possibility that PART support or opposition followed party lines. Given that the executive who was responsible for creating PART was a Republican it can be argued that PART should have had more support among Republicans.

The third control variable-appropriations_explores the role that membership on Appropriations committees might have on legislators' sentiment towards PART. Membership on this committee carries with it prestige and power. Changes to the process of appropriation, through reforms such as PART, could directly impact the value of committee membership. Therefore, appropriations committee members are more likely to not support PART-like initiatives. 
The final control variable—divided government—controls for the influence of government fragmentation. It could also be used as an indicator of support for the agenda of President Bush. PART was utilized during periods of both unified (2003-2006) and divided (2007-2008) government. During the initial years of PART implementation, which took place during a time of unified government, we expect congressional PART support to reflect support for the Bush Administration's agenda. This would especially be the case for Republican congressmen who would be expected to demonstrate unity with the President, especially since there had not been a unified government during a Republican presidency since 1955. However, the steady encroachment of executive power could have eroded this support resulting in a congressional pushback during the period of divided government.

Table 8: Independent Variables

\begin{tabular}{|c|c|c|c|}
\hline $\begin{array}{l}\text { Independent } \\
\text { Variable }\end{array}$ & Measure & Data Source & Definition of Variable \\
\hline Ideology & DW-Nominate & DW-Nominate & $\begin{array}{l}\text { DW-NOMINATE scores from } \\
\text { http://voteview.com/dwnomin.htm }\end{array}$ \\
\hline $\begin{array}{l}\text { Campaign } \\
\text { Financing (PACs)* }\end{array}$ & Dollar Amount & $\begin{array}{l}\text { Federal Election } \\
\text { Commission }\end{array}$ & $\begin{array}{l}\text { Campaign dollar amount received other than party and } \\
\text { individuals during the election cycle in which the comment } \\
\text { was made (in thousands), Federal Election Commission; } \\
\text { Summary Reports Search; } \\
\text { http://www.fec.gov/finance/disclosure/srssea.shtml }\end{array}$ \\
\hline Business Experience & $\begin{array}{l}\text { Dummy } \\
\text { Variable }\end{array}$ & $\begin{array}{l}\text { Biographical } \\
\text { Directory of the } \\
\text { U.S. Congress }\end{array}$ & $\begin{array}{l}\text { 1= Yes; } 0=\text { No; (i.e. business owner, business executive) as } \\
\text { documented in Biographical Directory of the U.S. Congress, } \\
\text { http://bioguide.congress.gov/biosearch/biosearch.asp }\end{array}$ \\
\hline $\begin{array}{l}\text { Time spent in } \\
\text { Congress }\end{array}$ & Years in Office & $\begin{array}{l}\text { Biographical } \\
\text { Directory of the } \\
\text { U.S. Congress }\end{array}$ & $\begin{array}{l}\text { Cumulative number of years of congressional service up to, } \\
\text { and including, the year the comment was made according to } \\
\text { the Biographical Directory of the U.S. Congress, } \\
\text { http://bioguide.congress.gov/biosearch/biosearch.asp }\end{array}$ \\
\hline Chamber $* *$ & $\begin{array}{l}\text { Dummy } \\
\text { Variable }\end{array}$ & $\begin{array}{l}\text { Biographical } \\
\text { Directory of the } \\
\text { U.S. Congress }\end{array}$ & $\begin{array}{l}1=\text { House; } 0=\text { Senate; if legislator switched chambers, the } \\
\text { predominate chamber during the period of study was used }\end{array}$ \\
\hline Seniority & $\begin{array}{l}\text { Dummy } \\
\text { Variable }\end{array}$ & $\begin{array}{l}\text { Committee } \\
\text { Reports }\end{array}$ & $\begin{array}{l}\text { 1=Legislators who served on power committees during this } \\
\text { period of study and } 0 \text { =Legislators not served on power } \\
\text { committees*** }\end{array}$ \\
\hline $\begin{array}{l}\text { Appropriations } \\
\text { (control variable) }\end{array}$ & $\begin{array}{l}\text { Dummy } \\
\text { Variable }\end{array}$ & $\begin{array}{l}\text { Committee } \\
\text { Reports }\end{array}$ & $\begin{array}{l}\text { 1=Legislator membership on Appropriations committee; } \\
0=\text { =egislator not a member of the Appropriations committee }\end{array}$ \\
\hline $\begin{array}{l}\text { Exposure } \\
\text { (control variable) }\end{array}$ & $\begin{array}{l}\text { Number of } \\
\text { Hearings }\end{array}$ & $\begin{array}{l}\text { Congressional } \\
\text { Hearings }\end{array}$ & $\begin{array}{l}\text { Number of hearings where PART was mentioned that } \\
\text { legislator attended }\end{array}$ \\
\hline $\begin{array}{l}\text { Party Affiliation } \\
\text { (control variable) }\end{array}$ & $\begin{array}{l}\text { Dummy } \\
\text { Variable }\end{array}$ & $\begin{array}{l}\text { Biographical } \\
\text { Directory of the } \\
\text { U.S. Congress }\end{array}$ & $\begin{array}{l}\text { 1=Republican; 0=Democrat; as documented in Biographical } \\
\text { Directory of the U.S. Congress, } \\
\text { http://bioguide.congress.gov/biosearch/biosearch.asp }\end{array}$ \\
\hline $\begin{array}{l}\text { Appropriations } \\
\text { (control variable) }\end{array}$ & $\begin{array}{l}\text { Dummy } \\
\text { Variable }\end{array}$ & $\begin{array}{l}\text { Committee } \\
\text { Reports }\end{array}$ & $\begin{array}{l}\text { 1=Legislator membership on Appropriations committee; } \\
0=\text { =egislator not a member of the Appropriations committee }\end{array}$ \\
\hline $\begin{array}{l}\text { Divided } \\
\text { Government } \\
\text { (control variable) }\end{array}$ & $\begin{array}{l}\text { Dummy } \\
\text { Variable }\end{array}$ & $\begin{array}{l}\text { Committee } \\
\text { Reports }\end{array}$ & $\begin{array}{l}\text { 1=Legislator made a comment about PART during the } 110 \text { th } \\
\text { Congress (the period of divided government) and } 0=\text { Legislator } \\
\text { did not make a comment about PART during the } 110 \text { th } \\
\text { Congress }\end{array}$ \\
\hline
\end{tabular}


* Adjusted to 2009 dollars

** Used predominate chamber membership if member changed chambers during the period of study

*** Appropriations, Finance, Rules in the Senate and Appropriations, Ways \& Means, and Rules in the House

The final step of the model building process was to assess the multicollinearity across variables. The correlation matrix indicated that the correlations between the different variables were relatively low, with the exception for the correlation between party and ideology. These two variables were originally included in the analysis in an effort to separate the influence of individual preferences (measured by ideology) from organizational preferences (measured by party). However, given that party affiliation is so closely correlated to ideology it was removed from the regression model.

\section{Descriptive Statistics}

As noted, a combined total of 6,967 hearing reports were identified and published for both chambers during the time period of study. A total of 454 of these hearings included PART-related statements by members of Congress (U.S. GPO, Congressional Hearings). The descriptive statistics reveals that these 454 comments were made by 167 different legislators. Forty-one of these legislators were clearly negative towards PART, fourteen were clearly positive, and 112 were neutral in tone. These descriptive statistics are consistent with the anecdotal evidence and findings discussed previously, which suggest that PART was either ignored or openly opposed by legislators.

Separated by chamber, the descriptive statistics reveals that 17 House members (3.2\% of all House members who served during the period of study) were negative towards PART and seven (1.3\%) were positive. In the Senate, 24 Senators (20.3\%) were negative and seven (5.9\%) were positive. Senators were also more likely to make PART- related comments with 0.80 comments per Senator.

An interesting finding from the descriptive data is that eight legislators (13.6\% of all PART commenters) were House freshmen during the Republican Revolution of the $104^{\text {th }}$ Congress. Of these commenters five commented negatively about PART and three made positive comments about PART. The 1994 elections gave majority control of the House of Representatives to the Republicans for the first time in 40 years. The House Republicans believed that America wanted a smaller government, term limits, a balanced budget, and the line-item veto. House Republicans of the $104^{\text {th }}$ Congress demonstrated much discipline and homogeneity of preferences. They were the third largest class of House freshmen in American history. It is possible that these seasoned freshmen did not embrace PART as a worthy tool for their agenda. 


\section{Regression Results}

The results from the regression model, prior to adding the control variables, are presented in Table 9. They indicate that the model has a moderate explanatory power with an R Square of 0.318 and an Adjusted R Squared of 0.233. However, it is important to note that the precision of the model might be compromised by the limited number of observations. As previously indicated, the coding of the comments for the period of study generated 167 observations. Among these observations, only 55 different legislators expressed clear opinions in favor or against PART.

The regression results suggest that two of the variables are statistically significant and carry the expected signs. First, the model offers statistically significant support for the hypothesis that legislators who have business experience are more likely to support PART $(\mathrm{p}<0.001)$. This is consistent with previous exploratory research, which has illustrated that professional business experience significantly influences House members' behavior (Witko \& Friedman, 2008). The model also suggests that legislators that received relatively more PAC support were less likely to support PART $(\mathrm{p}<0.023)$.

Ideology carries the correct sign suggesting that conservative legislators tend to be more supportive of PART. However, this variable is not statistically significant $(\mathrm{p}<0.321)$. The remaining three variables — exposure, years, and seniority—are also statistically insignificant.

Table 9: Regression Results (without controls)

\begin{tabular}{|c|c|c|c|c|c|}
\hline Model & $\mathbf{R}$ & R Square & $\begin{array}{c}\text { Adjusted R } \\
\text { Square }\end{array}$ & \multicolumn{2}{|c|}{$\begin{array}{l}\text { Std. Error of } \\
\text { the Estimate }\end{array}$} \\
\hline 1 & $.564^{\mathrm{a}}$ & .318 & .233 & & 38507 \\
\hline \multirow{2}{*}{ Model } & \multicolumn{2}{|c|}{ Unstandardized Coefficients } & Standardized & $\mathrm{T}$ & Sig. \\
\hline & $\mathrm{B}$ & Std. Error & Beta & & \\
\hline \begin{tabular}{l|l}
1 & (Constant)
\end{tabular} & .273 & .186 & & 1.462 & .150 \\
\hline \begin{tabular}{|l} 
Ideology \\
\end{tabular} & .127 & .127 & .134 & 1.004 & .321 \\
\hline Chamber & .004 & .113 & .004 & .034 & .973 \\
\hline Years & .004 & .007 & .085 & .588 & .559 \\
\hline Business Exp. & .434 & .120 & .474 & 3.622 & .001 \\
\hline PAC Monies & $-3.450 \mathrm{E}-7$ & .000 & -.291 & -2.344 & .023 \\
\hline Seniority & -.070 & .113 & -.080 & -.619 & .539 \\
\hline
\end{tabular}

The most important change resulting from the addition of the control variables to the model is that the "seniority" variable becomes statistically significant $(\mathrm{p}<0.04)$. As displayed in Table 10 , this variable also carries the expected sign suggesting that senior legislators are more likely to be negative 
towards PART. This expectation is consistent with Joyce's (2008) argument that powerful members of Congress tend to perceive attention to performance as a potential threat to their ability to control the allocation of resources. The other two explanatory variables remain statistically significant, carrying the correct signs.

One of the control variables—appropriations—is statistically significant ( $\mathrm{p}<0.037)$. Contrary to expectation this variable carries a positive sign, which suggests that legislators with a membership on appropriations committees are more likely to support PART. A possible explanation is that members of the Appropriations Committee are supportive of PART-like initiatives because it supports their ability to protect the public purse.

Table 10: Regression Results (with controls)

\begin{tabular}{|c|c|c|c|c|c|c|}
\hline Model & $\mathbf{R}$ & R Square & \multicolumn{2}{|c|}{ Adjusted R Square } & \multicolumn{2}{|c|}{$\begin{array}{l}\text { Std. Error of the } \\
\text { Estimate }\end{array}$} \\
\hline 1 & $.655^{\mathrm{a}}$ & .429 & & .315 & & 6397 \\
\hline \multirow{2}{*}{\multicolumn{2}{|c|}{ Model }} & \multicolumn{2}{|c|}{ Unstandardized Coefficients } & Standardized & \multirow[t]{2}{*}{$\mathrm{T}$} & \multirow[t]{2}{*}{ Sig. } \\
\hline & & $B$ & Std Frror & Beta & & \\
\hline \multirow[t]{10}{*}{1} & (Constant) & .360 & .199 & & 1.807 & .077 \\
\hline & Ideology & .045 & .123 & .048 & .368 & .715 \\
\hline & Chamber & -.006 & .118 & -.007 & -.050 & .961 \\
\hline & Years & .001 & .007 & .011 & .077 & .939 \\
\hline & Business Exp. & .466 & .114 & .509 & 4.082 & .000 \\
\hline & PAC Monies & $-3.762 E-7$ & .000 & -.318 & -2.488 & .017 \\
\hline & Seniority & -.299 & .142 & -.343 & -2.111 & .040 \\
\hline & Exposure & -.002 & .006 & -.054 & -.381 & .705 \\
\hline & Divided Govt & .644 & .428 & .198 & 1.505 & .139 \\
\hline & Appropriations & .357 & .166 & .379 & 2.151 & .037 \\
\hline
\end{tabular}

Chamber is negatively associated with PART comments, suggesting that legislators who favor PART are more likely Senators. This is consistent with the theory presented in the hypothesis; however, this variable is not statistically significant. A closer examination of the PART-related comments offers a possible explanation of the sign. Two of the dominant advocates of PART were Senators, Wayne Allard and Tom Coburn. Senator Coburn was Chairman of the Federal Financial Management, Government Information, and International Security subcommittee of the Committee on Homeland Security and Governmental Affairs; giving the Senator more control over subcommittee hearings and more opportunities to push PART. Senator Allard persistently asked hearing witnesses about PART and frequently advocated PART legislation (as documented by the Congressional Record). 
The third control variable — divided government—is also statistically insignificant $(\mathrm{p}<0.139)$. Contrary to expectation it carries a positive sign, suggesting that legislators were relatively positive towards PART. A possible explanation of this is that the inclusion of PART information in congressional justification material lead to a build-up in congressional resistance toward PART that appears to have culminated in 2006. As displayed in the Table 10, the addition of the controls also resulted in a slight increase in the explanatory strength of the model. The R Square improved from 0.318 to 0.429 and the Adjusted R Square improved from 0.233 to 0.315 .

\section{Discussion}

This research provides two sets of insights that have several possible implications for our understanding of PART and PART-like reform initiatives. First, as indicated by the analysis, the data suggests a positive link between the level of business experience legislators have and their support for PART. It also suggests that the level of campaign contributions they received from PACs adversely influence their support for PART. These insights should have implications for future research efforts aimed at broadening our understanding of why Congress tends to ignore or reject executive performance budgeting initiatives. Perhaps most important, the model developed in this research serves as a framework for future research efforts aimed at enhancing our ability to track and predict the success of next generation executive reform initiatives.

Second, this research provides important insights into the overall exposure and sentiment toward PART. Specifically, the data indicates that $86 \%$ of the 650 legislators that served in Congress during the period of study were exposed to PART and that only 55 of the 167 different legislators that commented on PART expressed a clear opinion regarding the tool. These insights draw attention to the implications that the separation of powers structure may have on the implementation of executive performance budgeting initiatives. This separation challenges progressive reform initiatives such as PART, because Congress and the President often differ in their perceptions of the value of executive administrative reform initiatives. Congress generally perceives these as being politicized by the Presidency and created for purposes of shifting policy control away from Congress (Moe, 1985). Using this logic, one would expect a relatively limited number of positive opinions among legislators towards the PART initiative.

The findings related to the limited number PART comments made by legislators also contribute towards a more nuanced view of PART. Previous findings and discussion around PART suggest that Congress has either ignored or been openly hostile to PART. The descriptive data collected and analyzed 
as part of this research, suggest that a very limited number of legislators were openly hostile towards PART. Among the 167 different legislators that had made comments about PART during the period of study, only 10\% expressed a negative sentiment towards PART. In fact, the data shows that among those legislators that expressed a clear opinion towards PART, twice as many members were positive rather than negative towards PART.

Finally, these insights may also have implications for contemporary discussions about the relationship between administrators and elected officials. As noted by Dunn and Legge (2002) much of the scholarly discussion of this relationship has taken place without examination of how practicing public

administrators relate to or experience their relationships with elected officials. This research adds to these discussions by providing evidence that questions a major premise of results-oriented reforms - the possibility that public administration can be conducted separately from politics; thereby ensuring a more efficient and accountable government based on expertise. The results of this study offer support to the notion that the Wilsonian separation of politics and administration is a false premise for budgetary reform. As such, it also gives credence to a broad range of writings that have questioned the value of a politicsadministration dichotomy (Niskanen, 1971; Tullock, 1965; Downs, 1957).

Beyond these possible implications, it may also be argued that the limited number of comments offers credence to Lindblom's concept of incrementalism, which is the antithesis of progressive-style budget reform initiatives and has shown to be compatible with Wildavsky's writings on the politics of budgeting (Wildavsky 1997).

\section{Conclusion}

This research adds insight into the congressional reaction to PART by exploring the influence of individual legislators’ personal experiences and ideological position on their sentiment toward PART. The analysis was conducted for purposes of exploring how six different factors influenced legislators' sentiment to PART, including legislators' ideological position, level of business experience, level campaign financing received from PACs, years spent in Congress, chamber, and seniority.

The analysis generated three key findings. First, it offered support for the hypothesis that legislators with higher levels of business experience tended to be more supportive of PART. Performance measurement is commonly used in business to manage projects, people, and budgets. Having gained first-hand experience with these types of tools, legislators with business experience can be argued to be more prone to accept and use performance-oriented frameworks to guide their decisions. This finding is 
consistent with previous research that suggests that the professional business experience of House members significantly influenced their behavior (Witko and Friedman, 2008).

Second, the results indicate that the amount of campaign contributions received by legislators from PACs is negatively related to PART support. This relationship suggests a perception of PART among legislators as a tool that has the potential to challenge their ability to return favors in response to PAC funding. This currying of favor can be argued to be the antithesis to a tool like PART, which was promoted as a neutral tool that would seek to objectively quantify the success of programs in the allocation of funding, as well as increase transparency and accountability of the appropriations process.

Finally, the analysis offers support for the hypothesis that that more senior legislators are more likely to be hostile to PART. Joyce (2008) identified this as the primary explanation to Congress' hostility or indifference to PART, suggesting that legislators generally were negative to PART because they saw its attention to performance as a potential threat to their ability to control the allocation of resources based on constituent concerns.

These findings are important because they draw attention to challenges associated with adopting sustainable performance-based budgeting and management systems at the federal level of government. They are also important for purposes of gaining a more comprehensive understanding of the congressional reaction to PART.

The next chapter assesses the congressional use of PART under a unified government, the 109th Congress. 


\section{Chapter 5}

\section{Congressional Use of PART: The $1^{109^{\text {th }}}$ Congress}

"This power over the purse may, in fact, be regarded as the most complete and effectual weapon with which any constitution can arm the immediate representatives of the people, for obtaining a redress of every grievance, and for carrying into effect every just and salutary measure.” James Madison (1788)

The previous chapter examined the characteristics that likely influence legislators' sentiment toward PART and provided insight into why PART failed to gain a foothold in Congress. This chapter assesses the congressional use of PART in the $109^{\text {th }}$ Congress. ${ }^{2}$ This session was chosen because it was the second of two Congresses under a unified government; if the President's reform will be supported, it should be when his party dominates government. The $109^{\text {th }}$ Congress was selected instead of the $108^{\text {th }}$ Congress to better determine the effects of on PART implementation. By the beginning of the $109^{\text {th }}$ Congress, $40 \%$ of all federal programs had been assessed with PART.

Like the previous chapters, the analysis in this chapter is based on congressional committee reports, which document the work of committees regarding proposed legislation and other matters of investigation (U.S. GAO, No Date). The analysis offers several insights. Most important, it indicates that for the 109th Congress, both the House of Representatives and the Senate used PART on a limited basis. Congressional committees are exposed to PART scores because of mandatory score inclusion in agency budget justifications and in agency testimony. Legislators that supported PART did so because of a desire for greater accountability and concern over a growing federal deficit, while those opposed to PART believed that assessments were contrary to their knowledge of specific programs.

Little research has examined the congressional use of PART. This limited knowledge is echoed by Moynihan (2006), "We know little about whether legislators discuss or dismiss PART, or are even aware of its existence” (p. 153). Another anecdotal statement is Gruber's (2003) account of a House Appropriations Committee staff member's comment stating that he had never used PART and had rarely heard it discussed by staffers.

Only one congressional study has directly addressed the congressional use of PART. This study was conducted by the GAO in 2005 and included interviews with House and Senate committee staff members from authorization and appropriations subcommittees for three departments and an independent agency about PART use (Department of Health and Human Services, Department of Energy, Department

\footnotetext{
${ }^{2}$ Content in this chapter previously published in Frisco, V. \& Stalebrink, O. J. (2008). Congressional Use of the Program Assessment Rating Tool. Public Budgeting \& Finance, 28(2), 1-19.
} 
of Labor, and the Small Business Administration). In addition to these interviews, the GAO also reviewed FY 2005 and 2006 congressional hearings and reports. The study found that some staff members would be more likely use the PART results to inform their deliberations if OMB consulted them early in the PART process regarding the selection and timing of programs to assess; explained the methodology and evidence used or to be used to assess programs; and discussed how the PART information can best be communicated and leveraged to meet their needs (U.S. GAO, 2005, p. 42).

The GAO study also reported that some congressional staff members acknowledged that PART information is among the numerous sources they use in assessing program performance. However, the GAO concluded that "it is not clear that the PART has had any significant impact on congressional authorization, appropriations, and oversight activities to date” (U.S. GAO, 2005, p. 44). Finally, the GAO study indicated that congressional staff criticisms of PART reflect the criticisms found in the literature.

With the exception of the GAO study, the literature on PART has been centered on the use of PART within the executive branch. Several of these studies make reference to the congressional use of PART, but fail to systematically study its use. In their analysis of the executive budget for FY 2007, Norcross and McKenzie (2006) stated, “Though PART scores and their application to budget decisions and policy remains the subject of debate in Congress and agencies, PART appears to have increased congressional interest in evaluating programmatic activity for results, improving reliable performance information, and advancing the goals of GPRA” (p. 4).

\section{Research Approach}

Using congressional hearing source documents from GPO Access, the analysis was conducted at five levels of aggregation: totals at the congressional level, by hearing type, chamber, committee, and by legislator. Limitations include errors common to subjective analyses, including the risk that not all committee reports were posted; the search was conducted using electronically available data only; the focus on committee reports may have excluded other credible sources of information; inadequate search terms; and that discussion of PART may be an indicator of congressional thinking that does not accurately capture congressional action.

\section{Descriptive Statistics}

An analysis of the data compiled indicates that in the $109^{\text {th }}$ Congress both the House of Representatives and the Senate referenced PART on a limited basis. The total number of reports identified with PART-related content was 100 out of a total of 1,688 hearing reports published for both 
chambers. PART-related hearings, approximates $6 \%$ of the total number of hearings analyzed in this study. This is a very low percentage, especially for a unified Congress.

\section{Analysis by Hearing Type}

Analysis by hearing type-legislative, investigatory, oversight, information gathering, and nomination and treaty-shows that the majority of these reports were legislative hearings with about 59\% for the House and 57\% for the Senate. As illustrated in Table 3, a more detailed analysis of legislative hearings identified 31\% of legislative hearings were budgeting for both chambers. About $8 \%$ in the House were appropriations compared to $18 \%$ for the Senate. General legislation comprised $20 \%$ for the House and $8 \%$ for the Senate. The next highest percentage by hearing type was oversight hearings with 27\% in the House and 33\% in the Senate. No investigatory hearings were identified for either chamber. The number of PART-related information gathering hearings was $14 \%$ in the House and $4 \%$ in the Senate. Finally, $6 \%$ of Senate PART-related reports were nomination hearings.

Table 3: PART-related Reports by Hearing Type $109^{\text {th }}$ Congress
\begin{tabular}{|l|c|c|c|c|}
\hline & \multicolumn{2}{|c|}{ HOUSE OF } \\
REPRESENTATIVES & \multicolumn{2}{c|}{ SENATE } \\
\hline Hearing Type & $\begin{array}{c}\text { No. } \\
\text { Reports }\end{array}$ & Percentage & $\begin{array}{c}\text { No. } \\
\text { Reports }\end{array}$ & Percentage \\
\hline Legislative - General & 10 & 20 & 4 & 8 \\
Legislative - Appropriations & 4 & 8 & 9 & 18 \\
Legislative - Budgeting & 15 & 31 & 16 & 31 \\
Investigatory & 0 & 0 & 0 & 0 \\
Oversight & 13 & 27 & 17 & 33 \\
Information Gathering & 7 & 14 & 2 & 4 \\
Nomination and Treaty & N/A & N/A & 3 & 6 \\
\hline Totals & $\mathbf{4 9}$ & $\mathbf{1 0 0}$ & $\mathbf{5 1}$ & $\mathbf{1 0 0}$ \\
\hline
\end{tabular}

Due to the nature of PART we would expect to see usage grouped among appropriations and budgeting, because agencies were required to integrate PART in their budget justification. In addition, PART scores are indicators of performance, which makes them useful in matters of oversight. The occurrence of PART information in general legislative and information gathering hearings indicate that program performance information was more broadly integrated. Perhaps surprisingly, PART was also mentioned in nomination hearings. In these hearings the nominee was asked if they would use PART if confirmed (U.S. Senate, 2005c). 


\section{Analysis by Committee}

Segregated by chamber, the number of reports mentioning PART was similar for both the House of Representatives and the Senate with 49 published PART-related reports for the House and 51 for the Senate. The total number of hearing reports published for the House in the $109^{\text {th }}$ Congress was approximately 1,033 and 655 for the Senate. The percentage of hearings in which PART was mentioned was $4.74 \%$ and $7.79 \%$, respectively. Figure 1 provides a list of PART-related reports by committee identified for the House.

As illustrated in Figure 1, the House committee producing the highest number of PART-related reports was the Committee on Government Reform with 12, followed by the Committee on Energy and Commerce with eight, and the Committee on the Budget with six. Seven house committees made no mention of PART, including Homeland Security, Judiciary, Small Business, and Veteran's Affairs. The lack of any mention of PART in these committees indicates that, contrary to OMB requirements, these agencies minimized the use of PART in justifications. These numbers drop dramatically to 14 reports for the House and 20 for the Senate (1.36\% and 3.05\% of total reports, respectively), when reports where legislators discussed PART were separated from reports that include agency or stakeholder PART testimony only.

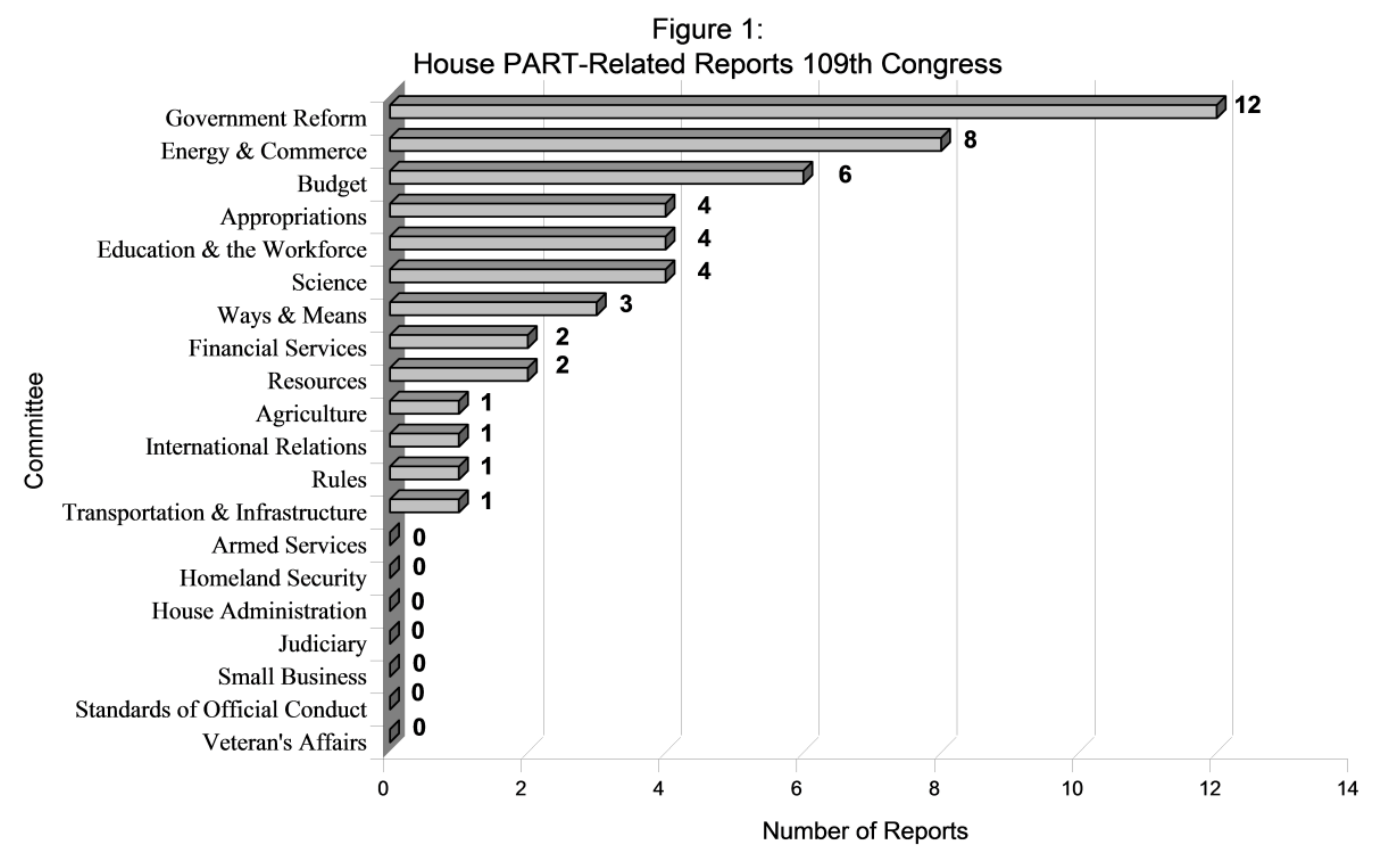

Activity in the committee on Government Reform centered on proposed legislation of PART-like reforms. The legislation failed to pass by a small margin of votes. This legislation was introduced under the name the Program Assessment Results Act (PARA) and was reported to the full House on March 17, 
2005 (H.R. 185), by the House Committee on Government Reform. The Act required the review of federal programs to evaluate their performance at least once every five years. The committee praised the “high level of transparency” achieved by OMB in reporting PART results” (U.S. House, 2005b, p. 3). They explicitly stated that "the PAR Act does not seek to codify the use of the PART specifically" (U.S. House, 2005b, p. 4). The PARA was introduced by House Republicans on January 4, 2005 and was approved by committee in a 19-14 vote. Two amendments were proposed during committee markup. The Towns Amendment, a Democratic initiative, proposed that OMB be required to make public notice and comment in the Federal Register of assessed programs, performance goals, and evaluation criteria. A sunset provision was added that would terminate the assessments in 2013. This amendment was defeated by one vote. A second amendment, also put forth by Democrats, required agency heads to conduct the assessment instead of OMB raters. This amendment failed by two votes. Placement on Union Calendar No. 12 was the last congressional action taken on the PARA. A previous effort to pass PARA was made during the 108th Congress (H.R. 3826).

The House Committee on Government Reform also discussed two other proposed bills in its September 27, 2005 report that, although not directly PART-related, are related to performance evaluation and measurement. The Government Reorganization and Improvement of Performance Act (H.R. 3276) sought to establish a commission to improve the results of executive branch agencies and the Federal Agency Performance Review and Sunset Act (H.R. 3277) establishes a commission to review program efficiency and determine program continuance. Agencies not reauthorized would be terminated within two years of the commission's review. Both H.R. 3276 and H.R 3277 were introduced by Republicans on July 14, 2005. Committee members had mixed opinions on the bills due to concerns such as the balance of power and the ongoing lack of proper oversight by Congress. Previously, both rules were referred to the Committee on Government Reform and to the Committee on Rules. The Rules committee did not conduct its hearing.

In the Senate, the Committee on Energy and Natural Resources produced the greatest number of PART-related reports with 15, as displayed in Figure 2. The Committee on Appropriations was next highest with nine, followed by the Committee on Indian Affairs with eight and the Committee for Homeland Security and Government Affairs with six. No discussion of PART was found in six committees including, Agriculture, Environment and Public Works, Judiciary, and Small Business. These results were similar to those of the House. Again, most surprising, is the lack of PART discussion within these committees, which indicate that these agencies chose not to comply with executive branch PART requirement. 


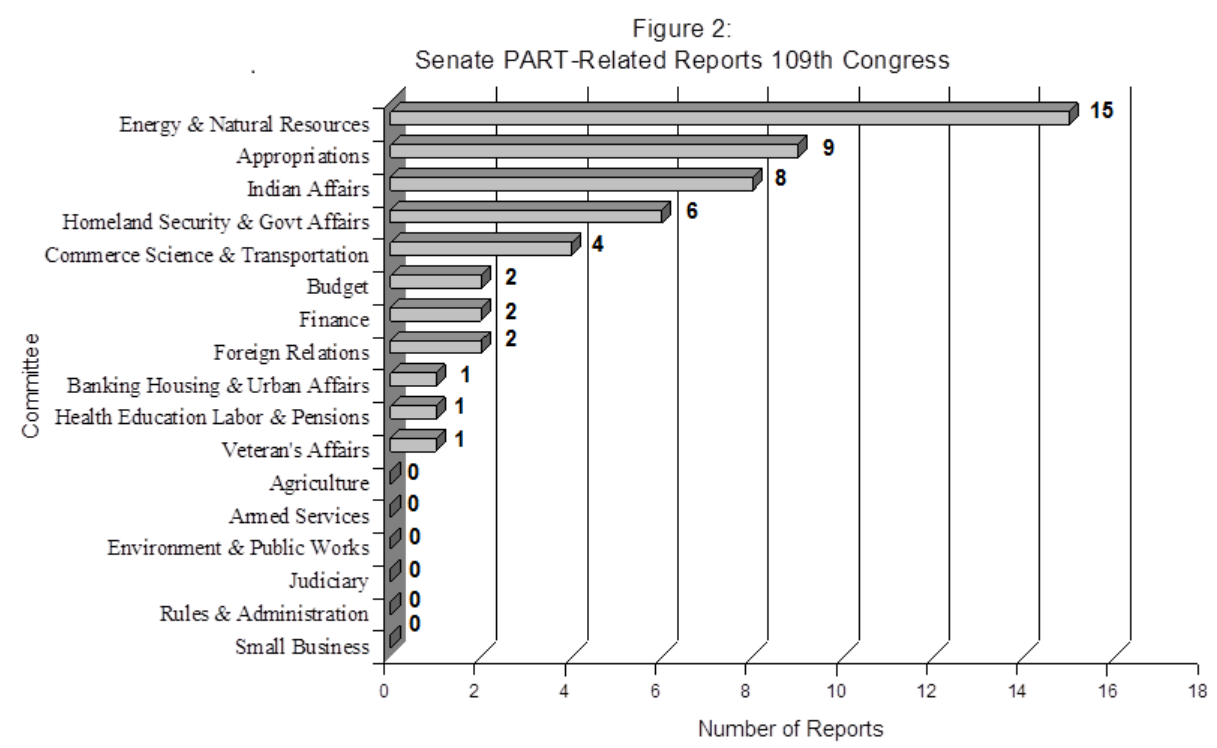

\section{Hearing Participants}

In order to determine what groups were driving the PART discussions, we must separate legislators from stakeholders. Comparing congressional participants with other stakeholders, 27\% of House committee reports included active congressional participation in PART-related discussions (see Table 4). The large difference demonstrates that non-congressional actors played the greater role in PART

Table 4: House PART-Related Committee Reports by Participant

\begin{tabular}{|l|l|l|l|}
\hline & \multicolumn{3}{|c|}{ Percentage of Reports } \\
\hline House Committee & $\begin{array}{l}\text { All } \\
\text { Participants }\end{array}$ & Congress & Difference \\
\hline Government Reform & 24.49 & 6.12 & 18.37 \\
\hline Energy \& Commerce & 16.33 & 2.04 & 14.29 \\
\hline Budget & 12.24 & 6.12 & 6.12 \\
\hline Appropriations & 8.16 & 4.08 & 4.08 \\
\hline Education \& the Workforce & 8.16 & 2.04 & 6.12 \\
\hline Science & 8.16 & 2.04 & 6.12 \\
\hline Ways \& Means & 6.12 & 0.00 & 6.12 \\
\hline Financial Services & 4.08 & 2.04 & 2.04 \\
\hline Resources & 4.08 & 0.00 & 4.08 \\
\hline Agriculture & 2.04 & 0.00 & 2.04 \\
\hline International Relations & 2.04 & 0.00 & 2.04 \\
\hline Rules & 2.04 & 0.00 & 2.04 \\
\hline Transportation \& Infrastructure & 2.04 & 2.04 & 0.00 \\
\hline & 99.98 & 26.52 & 73.46 \\
\hline
\end{tabular}


discussions in the House. The committees most affected were Government Reform and Energy and Commerce with stakeholders dominating discussion participation. There was no engagement of legislators at all in five committees, including Resources, Agriculture, International Relations, Rules, and Ways and Means. It is interesting that PART would even be mentioned in the Way \& Means committee, because this committee is more focused on revenue and taxation.

Approximately 39\% of Senate committee reports included active congressional participation in PART-related discussions (see Table 5). In the Senate, the Committees on Energy \& Natural Resources demonstrated much participation with congressional participants leading other stakeholders by a small margin. The Indian Affairs and Appropriations committees also demonstrated more stakeholder participation. There was no engagement of senators in the Commerce, Foreign Relations, Veteran's, and Finance committees. These results are similar to their parallel committees in the House.

Table 5: Senate PART-Related Committee Reports by Participant

\begin{tabular}{|l|l|l|l|}
\hline & \multicolumn{3}{|c|}{ Percentage of Reports } \\
\hline Senate Committee & $\begin{array}{l}\text { All } \\
\text { Participants }\end{array}$ & Congress & Difference \\
\hline Energy \& Natural Resources & 29.41 & 15.69 & 13.72 \\
\hline Appropriations & 17.65 & 5.88 & 11.77 \\
\hline Indian Affairs & 15.69 & 1.96 & 13.73 \\
\hline Homeland Security \& Govt Affairs & 11.76 & 9.80 & 1.96 \\
\hline Commerce Science \& Transportation & 7.81 & 0.00 & 7.81 \\
\hline Budget & 3.92 & 1.96 & 1.96 \\
\hline Finance & 3.92 & 0.00 & 3.92 \\
\hline Foreign Relations & 3.92 & 0.00 & 3.92 \\
\hline Banking Housing \& Urban Affairs & 1.96 & 1.96 & 0.00 \\
\hline Health Education Labor \& Pensions & 1.96 & 1.96 & 0.00 \\
\hline Veteran's Affairs & 1.96 & 0.00 & 1.96 \\
\hline \multicolumn{1}{|c|}{ Senate Total } & 100.00 & 39.21 & 60.75 \\
\hline
\end{tabular}

The differences between the total reports and those that exclude agency and stakeholder testimony indicate that the contribution to the discussion made by these two groups are much greater than those made by legislators in the majority of committees in both chambers. This suggests that 
congressional exposure to PART is greater than congressional use and that the discussion is primarily driven by non-congressional actors.

\section{PART Discussion Topics}

PART discussion within committees in the $109^{\text {th }}$ Congress focused on two areas: generalized discussion of PART use as a tool and a more focused discussion of PART evaluations for specific programs. The committees on the Budget, Transportation, and Government Reform primarily focused on general discussion of PART as a tool. For example, the Committee on the Budget recommended that Congress use PART “in authorization, appropriations, and oversight of program management and performance” in its concurrent resolution for FY 2007 (U.S. House, 2006b, p. 126). Discussions in the committees on Energy, Education, Science, and Financial Services discussed PART within larger discussions of program performance.

An example of the use of PART as a tool for improved program management was found in a June 9, 2006 report to the full House, the Departments of Transportation (DOT), Treasury, HUD, Judiciary, District of Columbia, and Independent Agencies Appropriations Subcommittee. This report was prepared after an acknowledgement by the Committee on Appropriations for some improvement in budget quality. It stated:

Most justifications continue to be filled with references to the Program Assessment Rating Tool (PART), drowning in pleonasm, and yet still devoid of useful information. The committee strongly encourages the administration to use a meaningful system of evaluation to justify proposed program funding levels, as long as the basis for the evaluations will also be shared with the Committee. The Committee finds little use for a budget justification which does not reveal specific details of the measurable indicators and standards used to evaluate a program's performance, relevance, or adherence to underlying authorization statute. Further, the Committee has little patience for secretaries and administrators who cannot explain the rationale behind a program's funding level other than "the PART score," "getting to green," or "this is what OMB provided" (U.S. House, 2006c, p. 4).

In a committee report to the full House, the Departments of Labor, Health and Human Services, and Education and Related Agencies Appropriations Subcommittee included a limitation rider that stated "no funds are provided in this Act to conduct or participate in conduct of a PART analysis or study without study approval from the Committee on Appropriations of the House and Senate” (U.S. House, 2006d, p. 4). Further, the committee requested that for FY 2008 all departments were required to provide "traditional congressional justifications" and that "fiscal year 2008 budget submissions shall not contain performance or performance integration information and shall not include Performance Assessment 
Rating Tool (PART) information or results” (U.S. House, 2006d, p. 238). However, such information could be submitted separately. MacDonald (2010) explained that “Congress attaches limitation riders to appropriations legislation when agencies attempt to create policies that stray too far from the policy preferences of congressional majorities” (p. 766). Because riders are frequently used it is interesting that this was the only PART-specific rider identified. If legislators believed PART to be an infringement on their institutional responsibilities, we would expect to see a greater negative response to PART.

Like its sister committee in the House, the Senate Transportation, Treasury, HUD, Judiciary, and Related Agencies Appropriations committee stated its displeasure with PART in its July 26, 2006 report to the Senate. The committee supported the concept, but stated that PART did not include "meaningful benchmarks and program goals" and that "the PART analysis appears to be overly subjective and designed to reach certain preconceived conclusions about a program's validity and accomplishments and its budget needs” (U.S. Senate, 2006, p. 5-6). Further, the committee expressed its concern about the absence of "fundamental and objective programmatic budget data that is critical to the work of the committee” (U.S. Senate, 2006, p. 6). As a result, the committee directed the agencies to submit the “customary level of detailed data and explanatory statements to support the appropriations requests” for the FY 2008 budgets (U.S. Senate, 2006, p. 6). Thus, both chambers of Congress reprimanded these agencies for their increased use of PART data at the expense of traditional budget information.

Within this subset of Senate committees reports that included active congressional participation in PART-related discussions, the discussions in the committees on the Budget, Homeland Security, Banking, and Health primarily focused on PART as a tool for achieving improved program management and budget allocation. The discussions in the committees on Energy, Appropriations, and Indian Affairs discussed PART within larger discussions of program performance. An anecdotal example of the latter is the Senate Committee on Energy and Natural Resources. In March 2005, the Secretary of the Interior justified the proposed funding termination for Land and Water Conservation Fund grants because it could not demonstrate results. Senators of both parties questioned the PART score and the proposed termination.

\section{Analysis by Legislator}

Analysis by legislator enables us to determine whether PART interest is widely dispersed, concentrated in a group of members, or is driven by individuals. Viewing the data from an individual standpoint demonstrates a variation of participants with a total of 40 different legislators discussing PART, with 19 in the House and 21 in the Senate. Of the 40 participants, 83\% (33) of legislators 
participated in single committee or subcommittee PART-related hearings; 13\% (5) participated in two hearings; 2\% (1) participated in three hearings; and 2\% (1) participated in four PART-related hearings. The legislator with the most participation (four hearings) was Senator Tom Coburn (R, Oklahoma), the Chairman of the Senate Subcommittee on Federal Financial Management, Government Information, and International Security of the Committee on Homeland Security and Government Affairs, who drove the discussion on PART. Four of the five Homeland Security committee Congress-only reports were from this subcommittee. Senator Coburn is a steadfast reformer and stalwart PART advocate. The Senator's comments focused on the use of PART as a tool.

Thus, participation was dispersed between a limited number of legislators. In addition, House members were more likely to assess PART as a tool rather than applied to program performance; whereas, the Senate was evenly divided between evaluation as a tool and in program performance.

A Republican House member of the Budgeting committee stated,

I heard, not only from my own constituents but from a number of members on both sides in developing the budget, that there was just no way we were going to be doing what the President suggested in his budget and what the PART came up with with (sic) regard to CDBG as an example” (U.S. House, 2005b, p. 16).

Some members, of both political parties and chambers, expressed a concern about politics and ideology in the evaluation process, and suggested the need for a non-partisan tool. An analysis of PART by the Congressional Research Service summarized, “... critics have seen the PART as overly political and a tool to shift power from Congress to the President, as well as failing to provide for adequate stakeholder consultation and public participation” (Brass, 2004, p. i). Dull (2006) called PART a congressional "nonstarter” and has said that the Republican Congress has purposefully limited criticisms of the tool itself. Serious concerns have been raised about Congressional use of PART by several groups including scholars, practitioners, and legislators themselves.

However, in general, when evaluating the performance of specific programs, legislators expressed their opinions of PART scores based primarily on their experiences with the programs. Radin (2002) observed "the closer that one gets to specific programs, the less that partisanship helps to explain congressional behavior” (p. 77). Two exceptions were PART discussions in the House Committee on the Budget and the proposed legislation of PART-like reforms in the House Committee on Government Reform.

Bipartisan support of performance-based budgeting in the House Committee on the Budget was led by Representatives who shared their experiences at the State level and who called for non-partisanship 
in budgeting. However, the discussion bifurcated into a partisan tone with Republicans stating their support of PART and Democrats questioning its use. Some Republicans were impressed with the use of PART and applauded the OMB and the Bush Administration for their efforts. Democratic representatives had concerns about the Bush Administration's problem in getting accurate information and the absence of impact assessments for proposed defunded programs. One Democrat spoke of the "bewildering pattern of what gets approved and what does not get approved" in the hands of the Chief Executive (U.S. House, 2006a, p. 28). Democrats questioned PART review and funding correlation of programs such as abstinence-only programs that are continually funded but have not demonstrated success; the National Nuclear Securities and Global Initiatives of Proliferation Prevention program, proposed for elimination by the President Bush, but considered “very, very effective” by a Democratic Representative; and Public Diplomacy and Public Affairs in the State Department, whose Under Secretary and former Bush Counselor to the President Karen Hughes, received the PART score of "results not demonstrated" because they were not able to demonstrate outcomes but was fully funded — also mentioned by a Democratic Representative.

In an analysis of the President's FY 2004 budget, federal programs that are traditionally Democratic (i.e., housing, health and human services) received less funding than other programs, but this trend was not present in the FY 2005 budget (Gilmour \& Lewis, 2006a, 2006b). However, the role of politics is seen in other ways. In FY 2006, President Bush requested \$206 million for abstinence-only education activities, which was an increase of \$39 million from the previous year even though there are no results documenting that abstinence programs work (Singer, 2005).

By 2006, Deputy Director Johnson acknowledged that some legislators were using PART to “improve programs” (Johnson, 2006). This likely means that the Administration was getting positive congressional feedback on the use of PART as evaluation tool for program management and performance, but not for purposes of budgeting.

Radin (2002) remarked that "GPRA data were used by Congress only to support pre-existing positions on specific programs” (p. 79). In general, Radin's observation can be applied to the use of PART for the $109^{\text {th }}$ Congress. In the House Committee on Government Reform, members paid much attention to the testimony of stakeholders that believed that PART inaccurately assessed Community Development Block Grants (CDBG) and questioned its validity for use in such programs. The Committee, in bipartisan disagreement with the use of PART, recommended that, "the administration should consider reviewing the applicability of the PART analysis for block grant programs that are 
designed to have broad programmatic goals, provide a high degree of flexibility to recipients, and are administered cooperatively among State and local stakeholders” (U.S. House, 2006e, p. 56).

It is important to note the disagreement among legislators regarding the link between GPRA and PART. Some legislators questioned how PART interfaced with GPRA, while others have believed that PART was built on GPRA to "better align budgetary decisions with program performance” (U.S. Senate, 2005b, p. 2).

\section{Findings and Discussion}

The discussion of PART in the $109^{\text {th }}$ Congress was very limited. The House of Representatives and the Senate used PART in about the same proportion and in similar ways. These discussions were primarily clustered in specific committees such as Appropriations, Budgeting, Energy, and Government Affairs/Reform, and appeared to be based on members' experience and interest. However, even these ties were not strong enough to bind partisan support of the President's reform.

Two trends emerged in the analysis of comments made by legislators regarding PART; the discussion on the use of PART as a tool and its use as applied to program performance. Few members discussed both aspects of PART. House members were twice as likely to judge PART as a tool than applied to program performance; Senators were evenly split between tool and program performance. Members that did not support PART believed that assessments were contrary to their knowledge of specific programs and questioned PART measurement effectiveness. Members that supported PART sought greater program accountability and expressed a concern about government spending.

In general, legislators from both parties supported the concept of performance-based budgeting. But those supporters were few. Although there was support in assessing program performance, there appeared to be less support for tying funding to that performance. Hearing reports do not include the detailed discussions and bargaining involved in the congressional funding process so we cannot accurately assess the full use of PART within the budgeting context. We can infer that for some programs PART informs the budget, but we cannot ascertain extent or strength. It is obvious that OMB has required the agencies to provide PART data as part of budget justification and in that way has integrated PART into the congressional budgeting process. This is reinforced by agency officials providing their PART scores and evaluations in congressional hearing testimony. However, the absence of PART testimony by some agencies indicates some agency push-back in PART implementation. 
These findings are important, because of the expanded use of PART in executive budget formation. Since its inception the number of PARTed programs expanded substantially. OMB evaluated approximately $20 \%$ of all programs each year using the PART framework. By the end of the $109^{\text {th }}$ Congress, 60\% of all federal programs had been PARTed. This was the second consecutive unified Congress. If there was any point in the Bush Administration where the President's will should have carried the day it would have been during this Congress. The support for PART was present but limited; most likely demonstrating a general congressional interest in performance assessment. Opposition was minimal and bipartisan.

\section{Conclusion}

This research into PART has demonstrated that we do not definitively know how Congress used PART. No evidence was found that establishes that PART was used in congressional appropriations. The legislature at various times in PART history expressed interest in this performance budgeting tool, but did not find enough value to embrace it.

Consistent with executive reform history, PART did not survive its maker. It was a significant investment for the President and consumed a high amount of effort in OMB and the agencies. PART was largely ignored by Congress and any effort to legislate PART-like reforms did not have the support needed to move forward. As observed by Groszyk (1995) “a lack of Congressional interest is likely to be fatal. What is not used eventually is no longer produced” (p. 12). The broad support expressed by those stakeholders that helped create the tool did little to ensure its use or survivability. The election of a Democrat as President sealed PART's fate; it was robbed of even symbolic value. 


\section{Chapter 6 \\ Disc ussion and Conclusion}

"Budget debate defines the playing field on which power and status are ultimately determined." Steven G. Koven (1988, p. 3)

Budget reforms provide context from which to view the power struggle between the executive and legislative branches of government. Five phases can be identified in reviewing the frame of budgetary reform. The first phase 1900-1950, focused on economy and efficiency. The focus of the 1950s was on improving and simplifying the budget. Reforms of the 1960s and 1970s were primarily interested in control of operations, information, agency goals, and the budget itself. The 1980s and 1990s reforms pursued deficit reduction. More recent budget reform initiatives focus on value for dollars spent. The trends in budget reform demonstrate that both the legislature and the executive are responsive to the problems of government. The identified phases relate to the issues of the time: the spoils system of patronage and waste; a growing bureaucracy created to alleviate societal ills, inequity, and inequality; uncontrolled spending with short-term tradeoffs and long-term debt.

\section{Historical Reform Sustainability}

Of the 16 reforms assessed, six were initiated by the executive. Of these six, only two were sustained - the Reorganization Act of 1939 and the Budget and Accounting Procedures Act of 1950. The Reorganization Act of 1939 was initiated by President Franklin Roosevelt. The goal of the Reorganization Act was to give help to the president. It succeeded in doing so by expanding the executive's span of control over the bureaucracy. However, this reform accomplished little regarding the federal budget. The Budget and Accounting Procedures Act of 1950 was initiated by President Harry Truman to simplify and modernize the budget; it succeeded by organizing the budget by function and activity. Of the remaining executive-initiated reforms, the sustainability of PPBS has been limited to the DOD. The remaining four executive budgeting initiatives were not sustained into the following administration. Clearly, the history of contemporary budget reform suggests that if the President wants to institute lasting budget reform it must be through legislation.

Legislative reforms, by their very nature, are more likely sustained than executive reforms. As observed by Groszyk (1995), “laws such as GPRA can be enduring monuments to governance; Presidential directives are more fragile edifices” (p. 2). The overriding observation can also be made that the legislature really does not want input from the executive unless requested. Executive-initiated, legislated budget reforms succeed when they are limited to the executive branch itself (Reorganization 
Act of 1939) or fixes aspects of the budget (Budget and Accounting Procedures Act of 1950); otherwise they have had limited influence and practically no sustainability.

According to Joyce (1993) previous reform efforts failed because they conflicted with the politics of the budgeting process, they were not incremental, and they required too much burdensome data. Nathan (2005) stated that the problem with reforms is that they are oversimplified and was oversold. Posner and Fantone (2007) believe that they were just not relevant to those making the budget decisions. They also observe that these efforts did not succeed because they were all creations of a single agency in one branch of the government (OMB). The bottom line, as stated by Rubin (1990), is that performance budgeting does not help make political choices.

\section{Historical Reform Findings}

Table 8 summarizes the reform frames and accomplishments. It is no surprise to find that the branch of government that initiated the reform was most likely the beneficiary. Not one executiveinitiated reform primarily benefited the legislature. However, the first interesting finding is that three legislative-initiated reforms brought more benefit to the executive branch. The first of these is the BAA, initiated during the Wilson Administration and signed by President Harding, was intended to increase efficiency and economy, and gain financial control. This legislation brought the largest historical change to the budget process-it gave the President responsibility for the budget. The ramifications of this Act are still reverberating through executive/legislative branch interactions. It will soon be a century since this legislation was enacted and yet neither branch has quite figured out how to negotiate a budget together.

The second reform was the Line Item Veto Act. Although requested by many presidents, Bill Clinton was the lucky recipient of this legislative gift. Framed as a way to reduce the deficit and control spending, in practice it did not do much of either. Immediately after the law was signed it was challenged in the courts. Legislators who disagreed with the President's vetoed items, sought to appeal the law.

The third reform is ZBB, which also includes one of the most interesting findings of this research. That ZBB as an executive reform introduced to Washington by President Carter has dominated the understanding of budgeting reform. However, the legislative record demonstrates that the first hearing specifically on ZBB, entitled “Zero-Base Budget Legislation,” was conducted by the House Budget Committee on June 30, 1976 pre-dating Carter’s election to the presidency (U.S. House, 1976). The use of ZBB was first included in proposed legislation in the Government Economy and Spending Reform Act (S. 2925) introduced in the Senate in February 3, 1976. Despite the fact that President Carter had used 
ZBB in Georgia and had been an advocate for its use in federal budgeting, it seems an incorrect reading of government activities to label ZBB as yet another failed example of executive budgeting reform. ZBB had

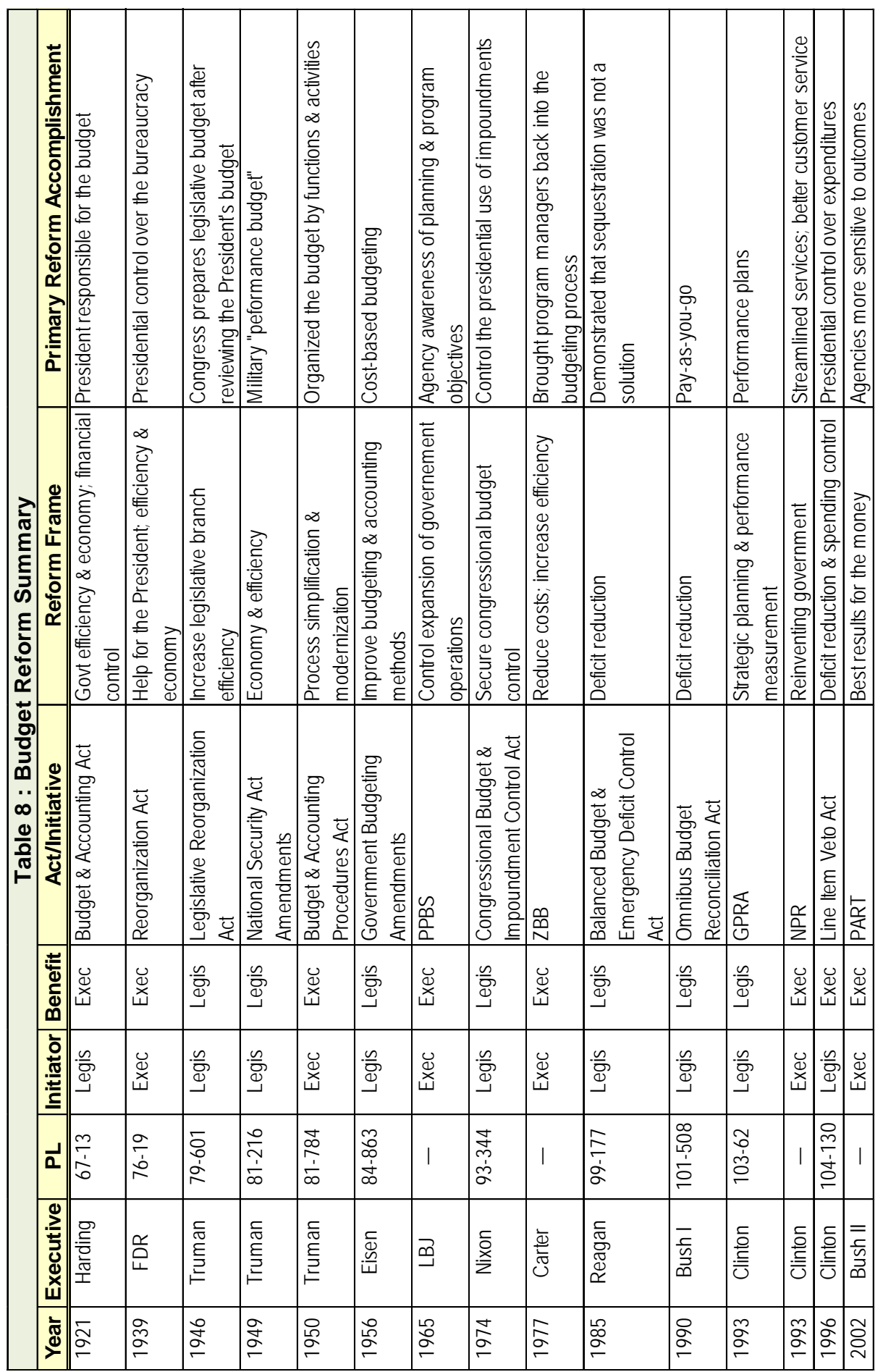


congressional, bi-partisan support. What we can learn from the ZBB experience is that legislators tend to provide more bipartisan support to initiatives that are first demonstrated in the States. In both the discussions of the use of ZBB and presidential line item veto, the dominant positive theme was the successful use of these tools in the States. ZBB was also the only legislative reform that was a rational budgeting method.

A second interesting finding was the lack of appreciation of time in moving legislation. While most budget reforms were enacted within the year it was introduced, others took a lot more time. The first hearing regarding what would become the Legislative Reorganization Act of 1946 was conducted in the House of Representatives on April 3, 1936 during the Roosevelt Administration. Almost 10 years later the Act was signed by President Truman (August 2, 1946). Likewise, the first hearing related to the Omnibus Budget Reconciliation Act of 1990 was conducted in the Senate on March 12, 1987 during the Reagan Administration and would become law under Bush almost three years later. Over 100 bills would be introduced before this legislation would become law. Although GPRA was signed by President Clinton, the bulk of the legislative work was conducted under President Bush. Legislation was first introduced in the Senate on October 1990; both the majority of the proposed bills and the number of days of hearings place most of the work under Bush. One can hardly credit the influence of Reinventing Government, as it was not published until two years later. Some authors, such as Radin (1998), have acknowledged this activity, but mostly it has been lost in reform rhetoric. The largest lag of time between the first congressional hearings and law promulgation is the Line Item Veto Act spanning April 1984 through April 1996 — through the Reagan, Bush, and Clinton Administrations. Almost 90 bills would be introduced before the Act became law.

A third interesting finding is two game-changers, in terms of executive-legislative power in federal budget reform, were identified during this period of study; the BAA and the CBICA. There is no doubt that bringing the president into the budgeting process with the Budget and Accounting Act immediately shifted the balance of power in the president's favor. What is surprising was the lack of much legislative dissent found in the primary sources. These were times when patronage and corruption were rife in public administration with the legislature tainted in the mind of the public.

The second game-changer is the CBICA. This legislation pulled budgeting power away from the president by "helping overcome a lack of coordination in budgeting that weakened the Congress vis-à-vis the executive; providing Congress with procedures that permit adopting a far more coherent budget policy than previously possible; and enabling Congress to exercise more deliberate control over the budget and 
deficit” (Gilmour, 1990, p. 224). An unintended consequence of this law is that it made the budget more difficult to pass.

\section{Differentiating PART from Previous Reforms}

As discussed in chapter two, PART follows a long list of reform efforts that achieved limited success in improving the allocation of federal funds and the performance of federal programs. Posner and Fantone (2007) noted the consensus that these previous efforts failed “...because they did not prove to be relevant by budget decision makers in the executive branch or Congress” (p. 352). An additional explanation for the failure of previous efforts is provided by Dull (2006) who attributed the failure of previous initiatives to a lack of resource commitment, like executive-driven efforts such as PPBS and ZBB. PART differs on both accounts and should be a viable candidate for congressional use. In regards to the relevance of the tool to the executive branch, three studies illustrate a link between PART ratings and executive budget formation. First, the U.S. Government Accountability Office recognized this connection in a GAO report from 2004 that stated,

Although OMB generally proposed to increase funding for programs that received the rating 'effective' or 'moderately effective' and proposed to cut funding for those programs that were rated 'ineffective,' our review confirmed OMB's statements that funding decisions were not applied mechanistically (2004b, p. 5).

Second, Gilmour and Lewis (2006a) illustrated that PART scores influence OMB's budgetary allocations for programs in the FY 2004 budget that traditionally have been housed in agencies considered more Democratic (i.e., Departments of Commerce, Education and Energy, Housing and Economic Development, Labor, Health and Human Services, and the Environmental Protection Agency).

Finally, based on a study of all programs (973 programs) rated for inclusion in the Bush Administration's proposed budget for FY 2008, Norcross and Adamson (2007) concluded that “effective programs tend to get increases, while ineffective programs tends to get decreases” (p. 31).

PART also differs from previous efforts in its support by significant resource commitments from the OMB. The development of the tool was driven by President Bush's first OMB director Mitch Daniels, who committed a substantial amount of OMB staff time in developing PART (Dull, 2006). In addition, federal agencies have also invested major commitments of resources to respond to the formal requirements associated with PART. 
If all that PART did was take hold in the executive branch, then it would come as no surprise that it would fall by the wayside like previous executive-initiated reforms. But the PART framework differs from previous efforts in that it is perceived to be more closely linked to decision-making processes traditionally favored by legislators. PART built on the foundations of GPRA, which formally links executive branch planning and congressional resource allocation. GPRA was the last sustained budget reform and is still in use. PART capitalizes on GPRA by "applying the information generated through GPRA to OMB decision making” (Dull, 2006, p. 197). The Bush Administration specifically marketed PART as an enhancement to GPRA, not as a replacement. PART sought to formalize the link between congressional decision-making by requiring agencies to consult with congressional representatives. This requirement was made explicit in the 2005 OMB Circular No. A-11, which included the following text,

You should consult with your congressional representatives to agree on the performance budget format, including the use of the results of PART assessments, prior to submitting your congressional justification. Your OMB representatives should be included in those consultations as appropriate (U.S. OMB, 2005b, sec. 22, pg. 4).

PART also formalized the link by requiring agencies to include their PART assessments in their budget request. This requirement can be traced back to a January 14, 2003 memorandum by former OMB Director Mitchell Daniels, which instructs executive department and agency heads,

To ensure the best available information is included in program justifications sent to the Congress, summaries of completed PARTs and their relation to the Administration's proposals should now be incorporated into the rationale for the budget request for all pertinent activities. In particular, they should be incorporated into your agency's Congressional justification materials. Performance information should enhance the Congressional Justifications without overwhelming the reader. And, this addition to the Congressional Justification will also provide agency performance data in a single document to the Congress (Daniels, 2003, pg. 1).

Although PART was touted as a companion piece to GPRA, in practice it seemed to have little relevance. Feller (2002) concluded, "rather than leading to a unified, consistent approach to planning and budgeting, recent federal government initiatives in performance measurement have led to a bifurcated, potentially competitive environment” (p. 446). Feller (2002) found the limitations in the use performance measures due to the flawed knowledge about the measurements and their cost-effectiveness, and the political contexts, which he believed

... transform a limited by reasonable technique that meets legitimate demands for accountability, effectiveness, and efficiency into substantively vacuous but effortdemanding undertaking. Performance measurement can be and has been a form of symbolic politics that provides political coverage for an organization with few significant impacts on the organizations. In my experience, it has also been a vehicle and veneer for 
opportunistic behavior directed at capturing resources and control but with dysfunctional impacts on the organization's long-term competitive capabilities (p. 449).

Perhaps, the biggest question after examining the PART experience is why the Bush Administration chose to introduce a new tool. While the Administration acknowledged its relatedness to the successful GPRA, it would have made more sense to provide a better cross-walk between this existing legislation and the budget than to create a new budgeting tool where this link remained unclear. American budget reform history clearly favors the legislated process. The CBO concluded in 1993, "If performance measurement is to gain renewed currency for either management or budgeting, the appropriate combination of legislative and executive activity must be applied. This entails understanding how each is limited in bringing about changes” (p. 43).

\section{PART Sustainability}

Another budgeting reform has failed to survive its creator. Viewed strictly as a performance measurement tool of the executive, PART appears to have been a success. However, the lack of interest in PART by the legislative branch, including the president's own party, undercut PART's sustainability. In order for a tool to be sustained it must be useful to the executive who submits funding requests and budget justifications, and to the legislature who is responsible for making the trade-off necessary to craft appropriations bills to fund federal programs. As demonstrated in previous chapters, congress was largely indifferent to PART. The death knell sounded for PART with the election of a presidential successor from the opposing political party whose priority for reform was focused on other areas of governance.

Institutions have made budgeting more difficult. The push and pull of power between the executive and legislative branches has been the steady bass line that has driven budget reform. Agendas and institutions may explain the observations and findings presented in this research. PART was included in President Bush’s President's Management Agenda; a major reform of the Bush Administration. In general, the legislative branch has little reason to promote the agenda of the executive, except for the role the President plays as the head of his political party. Furthermore, PART’s ideological roots, the executive's minimal effort to solicit opinion from Congress in the initial development of PART, coupled with President Bush's attitude of executive primacy at the expense of the other branches, likely undercut the acceptance of this tool. Legislators have their own agenda that primarily involves providing value to their constituents and securing re-election. Programs that the President deems as a worthy differs from what legislators support due to the differences in representation. Members of the House, elected for twoyear terms, must constantly demonstrate that they are working for their constituents; one of the ways they prove this by bringing home federal dollars. Presidents and Senators have the luxury of four- and six-year 
terms, respectively, in which to demonstrate their value to their constituents. As representatives of geographically based constituencies legislators focus on local concerns and priorities, as opposed to the nationally elected executive whose focus is broader. When people and interests put their money behind candidates, they expect return on their investment. Politicians know that you must "dance with the one who brought you.” Jones and McCaffery (2002) noted, “In the budget process, there is an intersection where the tools of professional articulation meet the needs of political representation” (p. 466).

The legislature likely gave little consideration to executive budgeting tools due to how they view their role. Although the BAA pulled the president into the budgeting process, budgeting still remains primarily the responsibility of the legislature.

The use of performance budgeting tools runs counter to how congress does business: compromise, reciprocity, and money grease the wheels of a successful congress. Therefore, the use of hard data to determine the funding of programs could only be one of many information sources used in budgeting. The Bush Administration openly published its PART evaluations on the Internet making this information available to the public. Such transparency in how legislators make funding decisions would open legislators to challenges about fairness, equity, and purpose. It is no wonder that legislators with more seniority, who are more accomplished in the ways of congress, and those that receive more PAC monies were less interested in PART.

It is possible that with time Congress found PART to be functionally innocuous, because it was acknowledged by the Bush Administration as only one of many indicators the president used in composing his budget. It is likely that recognition by legislators of the growing budget deficit and the value of such a tool to better manage spending kept PART sentiment from a net negative tone. The use of performance-based tools provides better managerial and fiscal control than incrementalism, thus giving the president an informational advantage. However, it is likely that legislators see limited value in a tool designed to measure performance over a bureaucracy to which they are not directly responsible. Because the bureaucracy is controlled by the executive, Congress has little skin in the game as to what the president uses to manage or assess government programs.

Ascendancy of the opposition party in the legislative branch and the declining popularity of the president may have depressed continued use of PART (Gallup, 2011). 
With the growing deficit and other economic woes it is likely that no legislator found it beneficial to expend political capital, and valuable time, to a reform effort that applies only to the discretionary part of the federal budget. The issues discussed in congressional committees are numerous; they cover a large range of topics and are addressed in a very short period of time. Members have agendas based on constituent, personal, and special interests; areas of experience and expertise; and reciprocity. They must strategically pick their battles and direct their interests due to constraints, such as time and resources. Cox and Terry (2008) found significant and large differences in productivity between committee leaders and committee members; between majority and minority members; and a larger positive effect regarding seniority and minority status. Perhaps it is as simple and as complicated as this:

Budget processes cannot be separated from the people who participate in them. Because budgets hold the key to the realization of human purposes, they are inevitably the focus of different agendas. The processes that put them together reflect the political systemits inconsistencies, rigidities, adaptabilities, and fragmentation. The budget serves many purposes, and its processes have adapted to accommodate them, according to the political configuration of the times (Wildavsky \& Caiden, 2004, p. 224).

\section{Considerations for Future Reforms}

What lessons can we divine from the PART experience? First, executive-initiated reforms are unlikely to be sustained unless they are shared with Congress and promulgated into law. Congressional input and participation is critical to reform survival. The Bush Administration put a high level of effort in creating the tool by bringing various stakeholders into the process. However, it neglected to include any legislators, whose use would have increased the likelihood that this reform would be sustained across subsequent administrations.

Second, the likelihood of congressional support for performance-based reforms, such as PART, is likely to increase as more legislators with a professional background in business are elected to the legislature. These individuals are familiar with performance measurement and outcome achievement.

Third, Congress has traditionally put more faith in reform that has been implemented in the states rather than directly from private industry, which is untried in the public realm. To many legislators, the difference is primarily that of scale and complexity.

Fourth, stakeholders did the Bush Administration a great disservice proposing the use of the “neutral” tool strategy to market PART, especially when some of those stakeholders were steadfast representatives of a single political ideology. This language cast a dissimulative patina to the tool, as few 
if any legislators believed this could possibly be true. Budgeting is a political act; as such politicians know that no activity can be neutral — to say so appeared disingenuous and increased suspiciousness of the president's intent.

Fifth, it is past time to free federal budgeting, and public administration in general, from the idea that the branches of government operate independent of politics. As a philosophy, it is noble to want a government free from corruption and cronyism. However, "politics” should not be solely judged as a pejorative term. Rather, it would behoove us to look at the ubiquity of politics as something naturally occurring, the result of the friction caused by our fragmented structures.

Sixth, the implementation of PART succeeded in ways not achieved by previous executiveinitiated reforms establishing a process for future reforms. A total of $20 \%$ of all federal programs were evaluated every year with nearly all programs PARTed by the administration's end. The speed and breadth of the implementation surpassed previous reforms.

What can we conclude about the American Grail? Perhaps Kettl (1992) said it best, "Budgetary reform is not a Holy Grail whose elixir mystically replaces conflict with peace. It cannot substitute analysis for politics. At best, it provides decision makers with useful information as they shape policy” (p. 91). 


\section{Bibliography}

Aberbach, J. D., \& Rockman. B. A. (2000). In the Web of Politics: Three Decades of the U.S. Executive. Washington, DC: Brookings Institution Press.

Anderson, B. (2012). Commentary: Playing the Wrong PART: The Program Assessment Rating Tool and the Functions of the President’s Budget. Public Administration Review, 72(1), 121-122.

Anderson, B., Davis, S., \& Gullo, T. (2003). The evolution of the federal budget process. Journal of Public Budgeting, Accounting \& Financial Management, 15(2), 239-250.

Antonelli, A., \& Sperry, P. B. (2001). A Budget for America. Washington, DC: Heritage Foundation.

Argyle, N. J., \& Barilleaux, R. J. (1986). Past Failures and Future Prescriptions for Presidential Management Reform. Presidential Studies Quarterly, 16(4), 716-733.

Arnold, D. R. (1990). The Logic of Congressional Action. New Haven: Yale University Press.

Arnold, P. E. (1976). The First Hoover Commission and the Managerial Presidency. Journal of Politics, 38(1), 46-70.

Arnold, P. E. (1998). Making the Managerial Presidency: Comprehensive Reorganization Planning, 1905-1996. Lawrence: University of Kansas.

Austin, D. A. 2013. Trends in Discretionary Spending. CRS Report for Congress. Congressional Research Service. RL34424.

Barber, J. D. 1985. Presidential Character: Predicting Performance in the White House, 3rd ed., Englewood Cliffs, NJ: Prentice Hall.

Benda, P. M., \& Levine, C. H. (1990). Reagan and the Bureaucracy: The Bequest, the Promise, and the Legacy. In R. E. DiClerico (Ed.), Analyzing the Presidency, Guilford, CT: The Duskin Publishing Group.

Benze Jr., J. G. (1985). Presidential Management: The View from Bureaucracy. Presidential Studies Quarterly, 15(4), 768-781.

Bernstein, M. H. (1970). The Presidency and Management Improvement. Law and Contemporary Problems, 35(3), 505-518.

Blanchard, L. A. (2008). PART and Performance Budgeting Effectiveness. In S. F. Redburn, R. J. Shea, \& T. F. Buss (Eds.), Performance Management and Budgeting: How Governments Can Learn From Experience (pp. 67-91). NAPA.

Botner, S. (1970). Four Years of PPBS: An Appraisal. Public Administration Review, 30(4), 423-431.

Bourdeaux, C. (2006). Do Legislatures Matter in Budgetary Reform? Public Budgeting \& Finance, 26(1), 120-142. 
Bordeaux, C., \& Chikoto, G. (2008). Legislative Influences on Performance Management Reform. Public Administration Review, 68(2), 253-265.

Brass, C. T. (2004). The Bush Administration's Program Assessment Rating Tool (PART), CRS Report for Congress, RL32663, Congressional Research Service.

Brudnick, I. A. (2011). The Congressional Research Service and the American Legislative Process, CRS Report for Congress, RL33471, Congressional Research Service.

Burrows, G., \& Syme, B. (2000). Zero-Base Budgeting: Origins and Pioneers. Abacus, 36(2), 226-241.

Chamberlain, L. H. (1946). The President, Congress and Legislation, New York, NY: Columbia University Press.

Cheney, D. (1990). Congressional Overreaching in Foreign Policy. In R. E. DiClerico (Ed.), Analyzing the Presidency, Guilford, CT: The Duskin Publishing Group.

Cleveland, F. A. (1915). Evolution of the Budget Idea in the United States. Annals of the Academy of Political and Social Science, 62, 15-35.

Cleveland, F. A., \& Buck, A. E. (1920). The Budget and Responsible Government, New York, NY: The Macmillan Company.

Cohen, J. E. (1988). The Politics of the U.S. Cabinet: Representation in the Executive Branch, 1789-1984, Pittsburgh, PA: University of Pittsburgh Press.

Cohen, M., March, J. G., \& Olsen, J. P. (1972). A garbage can theory of organizational choice. Administrative Science Quarterly, 17(1), 1-25.

Collins, C. W. (1917). The National Budget System. New York, NY: The Macmillan Company.

Cooper, P. J. (2005). George W. Bush, Edgar Allan Poe, and the Use and Abuse of Presidential Signing Statement. Presidential Studies Quarterly, 35(3), 515-532.

Cowen, S. S., \& Bezik, C. (1979). The U.S. Government Experience with ZBB: Some Insights and Observations for Potential Governmental Units. Urban Systems, 4(3-4), 221-231.

Cox, G. W., \& Terry, W. C. (2008). Legislative Productivity in the 93rd-105th Congresses. Legislative Studies Quarterly, 33 (4): 603-618.

Cullather, K. K. (1995). Budget Summits: A Consensus Building Approach to the Federal Budget Process. Presidential Studies Quarterly, 25(3), 511-531.

Daniels, M. E. (2003). Program Assessment Rating Tool (PART) - Presentation in Congressional Justifications, Memorandum M-03-06. Retrieved December 29, 2011 from www.whitehouse.gov/ omb/memoranda/m03-06.html.

Davidson, R. H. (1991). The Presidency and Three Eras of the Modern Congress. In J. M. Thurber (Ed.), Divided Democracy: Cooperation and Conflict Between the President and Congress, Washington, DC: Congressional Quarterly Press. 
Davidson, R. H., \& Oleszek, W. (2004). Congress and its Members. Washington, DC: Congressional Quarterly Press.

Deering, C. J., \& Smith, S. S. (1997). Committees in Congress, Third Edition, Washington, DC: Congressional Quarterly Press.

DeMaio, C. (2000). Transitioning to a Performance-Based Government: A Report to the $43^{\text {rd }}$ President and 107th Congress. Washington, DC: The Performance Institute. Retrieved June 11, 2013 from http://www.performanceinstitute.org/pdfs/transition-2153.pdf

DiClerico, R. E. (1990). Analyzing the Presidency, 2nd ed., Guilford, CT: The Duskin Publishing Group.

Downs, A. (1957). An Economic Theory of Democracy. New York: Harper and Brothers.

Draper, F. D., \& Pitsvada, B. T. (1981). ZBB—Looking Back After Ten Years. Public Administration Review, 41(1), 76-83.

Dull, M. (2006). Why PART? The Institutional Politics of Presidential Budget Reform. Journal of Public Administration Research and Theory, 16(2), 187-215.

Dull, M. (2009, October 2). De-PART: Assessing the Legacies of the Program Assessment Rating Tool for Management and Budgeting. Public Management Research Conference, Columbus, OH.

Dunn, D. D., \& Legge, J. (2002). Politics and Administration in U.S. Local Governments. Journal of Public Administration Research and Theory, 12(3), 401-422.

Dwight D. Eisenhower Library. (1970). U.S. President’s Advisory Committee on Government Organization: Records, 1953-61, Retrieved May 27, 2013 from http://www.eisenhower. archives.gov/research/finding_aids/pdf/US_Presidents_Advisory_Committee_Government_Orga nization.pdf

Edwards III, G. C. (1978). The President and Congress: The Inevitability of Conflict. Presidential Studies Quarterly, 8(3), 245-257.

Edwards III, G. C. (1980). Presidential Legislative Skills as a Source of Influence in Congress. Presidential Studies Quarterly, 10(2), 211-223.

Elmendorf, D. W. (2011). Discretionary Spending: Testimony before the Joint Select Committee on Deficit Reduction. Washington, DC: Congressional Budget Office.

Emmerich, H. (1971). Federal Organization and Administrative Management. AL: University of Alabama Press.

Executive Office of the President. (2007, February). Major Savings and Reforms in the Presidents 2008 Budget.

Feller, I. (2002). Performance Measurement Redux. American Journal of Evaluation, 23(4), 435-452.

Fenno, R. (1966). The power of the purse: Appropriations politics in Congress. Boston, MA: Little, Brown. 
Fenno, R. F. Jr. (1968). The Impact of PPBS on the Congressional Appropriations Process. In R. L. Chartrand, K. Janda, \& M. Hugo (Eds.), Information Support, Program Budgeting, and The Congress. New York, NY: Spartan Books.

Fenno, R. F. (1978). Home Style: House Members in their Districts. Little, Brown.

Fenno, R. F., \& Calvert, R. L. (1994). Strategy and Sophisticated Voting in the Senate. Journal of Politics, 56(2), 349-376.

Ferejohn, J., \& Krehbiel, K. (1987). The Budget Process and the Size of the Budget. American Journal of Political Science, 31(29), 296-320.

Fesler, J. W. (1975). Public Administration and the Social Sciences: 1946 to 1960. In F. C. Mosher (Ed.), American Public Administration: Past, Present, Future. University, AL: University of Alabama Press, 97-141.

Finer, H. (1949a). The Hoover Commission Reports. Political Science Quarterly, 64(3), 405-419.

Finer, H. (1949b). The Hoover Commission Reports: Part II. Political Science Quarterly, 64(4), 579-595.

Foreman, C. H., Jr. (1991). Legislators, Regulators, and the OMB: The Congressional Challenge to Presidential Regulatory Relief. In J. M. Thurber (Ed.), Divided Democracy: Cooperation and Conflict Between the President and Congress, Washington, DC: Congressional Quarterly Press.

Frisco, V. \& Stalebrink, O. J. (2008). Congressional Use of the Program Assessment Rating Tool. Public Budgeting \& Finance, 28(2), 1-19.

Gallup. 2011. Presidential Approval Rating - George W. Bush. Retrieved December 26, 2011 from www.gallup.com/ poll/116500/Presidential-Approval-Ratings-George-Bush.aspx\#1.

Gemen, B. (2004, November 30). Supporters eye expanded use of controversial OMB budget tool. Greenwire, 10(9).

Gilmour, J. B. (1990). Reconcilable Differences? Congress, the Budget Process, and the Deficit. Berkeley, CA: University of California Press.

Gilmour, J. B., \& Lewis, D. E. (2006a). Assessing Performance Budgeting at OMB: The Influence of Politics, Performance, and Program Size. Journal of Public Administration Research and Theory, 16(2), 169-186.

Gilmour, J. B., \& Lewis, D. E. (2006b). Does Performance Budgeting Work? An Examination of the Office of Management and Budget’s PART Scores. Public Administration Review, 66(5), 742752.

Glenn, B. (1958). Search for Efficiency in Federal Record Management: Introduction. The American Archivist, 21(2), 159-162.

Gore, A. (1993). From Red Tape to Results: Creating a Government That Works Better and Costs Less: Report of the National Performance Review. Washington, DC: GPO. 
Grizzle, G. A. (1986). Does Budget Format Really Govern the Actions of Budgetmakers? Public Budgeting \& Finance, 6(1), 60-70.

Groszyk, W. (1995). Implementation of the Government Performance and Results Act of 1993, a paper prepared for a Meeting Convened by the Organization of Economic Cooperation and Development of national experts on performance management, Paris, France. Retrieved June 2, 2013 from http://www.dtic.mil/cgi-bin/GetTRDoc?AD=ADA332621.

Gruber, A. (2003, June 13). OMB ratings have little impact on Hill budget decisions. Government Executive. Retrieved January 27, 2007 from http://www.govexec.com/dailyfed/0603/ 061303a1.htm.

Gueorguieva, V., Accius, J, Apaza, C., Bennett, L., Brownley, C., Cronin, S., et al. (2009). The Program Assessment Rating Tool and the Government Performance and Results Act: Evaluating Conflicts and Disconnections. The American Review of Public Administration, 39(3), 225-245.

Haider, D. F. (1977). Zero Base; Federal Style. Public Administration Review, 37(4), 400-407.

Hall, R. H. (1968). Professionalization and Bureaucratization. American Sociological Review, 33(1), 91104.

Handley, D. M. (2007). Challenges of Bottom-Up Implementation: The Community Development Block Grant and the Government Performance and Results Act. Journal of Public Administration and Management, 12(4), 70-95.

Harding, W. G. (1921). Business in Government and the Problem of Governmental Reorganization for Greater Efficiency. Academy of Political Science Proceedings, 9(3), 430-431.

Heclo, H. (1984). Executive Budget Making. In G. B. Mills \& J. L. Palmer (Eds.), Federal Budget Policy in the 1980s, Washington, DC: The Urban Institute Press.

Heclo, H. (1994). Ideas, Interests, and Institutions. In L. C. Dodd \& C. Jillson (Eds.), The Dynamics of American Politics, Boulder: Westview Press.

Herzlinger, R. E. (1979). Zero-Base Budgeting in the Federal Government: A Case Study. Sloan Management Review, 20(2), 3-14.

Ho, A. (2009). Comparing the Executive and Congressional Use of the PART. 2009 APPAM Fall Research Conference, 5-7 November in Washington, DC.

Hobbs, E. H. (1953). Executive Reorganization in the National Government. Oxford, MS: University of Mississippi Press.

Hughes, A. (2006, June 13). Testimony Before the Senate Homeland Security and Government Affairs Subcommittee on Federal Financial Management, Government Information, and International Security. Retrieved July 18, 2006 from http://coburn.senate.gov/ffm/index.cfm? FuseAction= Files.View\&FileStore_id=56e2b89c-0cde-4c66-9d88-fe1bfdca237f.

Huntington, S. P. (1984). Congressional Responses to the Twentieth Century. In T. Ferguson \& J. Rogers, (Eds.), The Political Economy: Readings in the Politics and Economics of American Public Policy, Armonk, NY: M.E. Sharpe. 
Inman, R. P. (1990, May). Public Debts and Fiscal Politics: How to Decide? The American Economic Review, Papers and Proceedings of the Hundred and Second Annual Meeting of the American Economic Association, 80(2), 81-85.

Jakab, S. (2012). Some Pluses Amid Large Budget Minuses. The Wall Street Journal. Retrieved March 11, 2012 from http://online.wsj.com/article/ SB1000142405297020396120457727193127916 1666.html.

Johnson III, C. (2006, June 13). Testimony of the Honorable Clay Johnson III Deputy Director for Management Office of Management and Budget before the Subcommittee on Financial Management, Government Information, and International Security of the Committee on Governmental Affairs United States Senate. Retrieved June 13, 2004 from http://coburn.senate.gov/ffm/ index.cfm? FuseAction= Files.View\&FileStore_id= 44dd518770b2-45fa-a804-56aee6a2508b.

Jones, C. O. (1994). The Presidency in a Separated System, Washington, DC: The Brookings Institution.

Jones, B. D., Baumgartner, F. R., \& True, J. L. (1998). Policy Punctuations: U.S. Budget Authority. The Journal of Politics, 60(1): 1-33.

Jones, L.R., \& McCaffery, J. (2002). Assessing Options for Changing the Federal Government Budget Process. Public Finance and Management, 2(3): 436-469.

Joyce, P. G. (1993). Using Performance Measures for Federal Budgeting: Proposals and Prospects. Public Budgeting \& Finance, 13(13), 3-17.

Joyce, P. G. (1996). Congressional Budget Reform: The Unanticipated Implications for Federal Policy Making. Public Administration Review, 56(4), 317-325.

Joyce, P. G. (2003). Linking Performance and Budgeting: Opportunities in the Federal Budget Process. Washington, DC: IBM Center for the Business of Government.

Joyce, P. (2007). Linking Performance and Budgeting Under the Separation of Powers: The Three Greatest Obstacles Created by Independent Legislatures. In M. Robinson (Ed.), Performance Budgeting: Linking Results and Funding, Palgrave-Macmillan.

Joyce, P. (2008, February 27). Linking Performance and Budgeting-A Framework and Current Update for the U.S. National Government. Public Financial Management Blog. Retrieved on January 14, 2010 from http://blog-pfm.imf.org/pfmblog/2008/02/ linking-perform.html.

Joyce, P. G. (2011a). The Obama Administration and PBB: Building on the Legacy of Federal Performance-Informed Budgeting? Public Administration Review, 71(3), 356-367.

Joyce, P. G. (2011b). Strengthening the Budget Committees: Institutional Reforms to Promote Fiscally Responsible Budgeting in Congress. The Pew Charitable Trusts. Retrieved August 27, 2013 from http://www.pewtrusts.org/uploadedFiles/wwwpewtrustsorg/Reports/Economic_Mobility/Strength ening-Budget-Committees-Jan-2011.pdf

Joyce, P. G., \& Reichauer, R. D. (1997). The Federal Line-Item Veto: What Is It and What Will It Do?, Public Administration Review, 57(2), 95-104. 
Kelly, J. M. (2003). The long view: Lasting (and fleeting) reforms in public budgeting in the twentieth century. Journal of Public Budgeting, Accounting \& Financial Management, 15(3), 309-326.

Kernell, S. (1997). Going Public: New Strategies of Presidential Leadership, Washington, DC: Congressional Quarterly Press.

Kettl, D. F. (1992). Deficit Politics: Public Budgeting in its Institutional and Historical Context. New York, NY: MacMillan Publishing Company, 175.

Kettl, D. F. (2000). The Global Public Management Revolution: A Report on the Transformation of Governance. Washington, DC: The Brookings Institution.

Kettl, D. F. (2003). Deficit Politics: The Search for Balance in American Politics. $2^{\text {nd }}$ Ed. New York, NY: Longman.

Key Jr., V. O. (1942). Politics, Parties, and Pressure Groups, New York, NY: Crowell.

Kiewit, D. R., \& McCubbins, M. D. (1988). Presidential Influence on Congressional Appropriation Decisions. American Journal of Political Science, 32(3), 713-736.

Kingdon, J. (1995). Agendas, Alternatives and Public Policies. $2^{\text {nd }}$ Ed. New York: Longman.

Koenig, L. W. (1996). The Chief Executive, 6th Ed., New York, NY: Harcourt Brace College Publishers.

Koven, S. G. (1988). Ideological Budgeting: The Influence of Political Philosophy on Public Policy. New York, NY: Praeger.

Kraines, O. (1970). The President Versus Congress: the Keep Commission, 1905-1909, First Comprehensive Presidential Inquiry Into Administration. Western Political Science Quarterly, 23(1), 5-54.

Krause, G. A. (1999). A Two-Way Street: The Institutional Dynamics of the Modern Administrative State, Pittsburgh, PA: University of Pittsburgh Press.

Kravitz, W. (1990). The Advent of the Modern Congress: The Legislative Reorganization Act of 1970. Legislative Studies Quarterly, 15(3), 375-399.

Krehbiel, K. (1991). Information and Legislative Organization. Ann Arbor, MI: The University of Michigan Press.

Laurent, A. (2000). The Results Act is Dead; Long Live the Results Act. Government Executive. Retrieved May 17, 2013 from http:/www.govexec.com/magazine/2000/05/the-results-act-is$\operatorname{dead} / 7164$.

Lauth, T. P. (1978). Zero-Base Budgeting in Georgia State Government: Myth and Reality. Public Administration Review, 38(5), 420-430.

Lee, R. D., Johnson, R. W., \& Joyce, P. G. (2008). Public Budgeting Systems, 8th ed. Sudbury: Jones and Bartlett Publishers, Inc. 
Levy, M. E. (1974, July/August). Reforming the Federal Budget Process. Challenge 17(3), 66-68.

Lindblom, C. E. (1959). The Science of 'Muddling Through. Public Administration Review, 19(2), 79-88.

Lindblom, C. E. (1968). The Policy-making Process, New Haven, CT: Yale University Press.

Lonti, Z., \& Gregory, R. (2007). Accountability or Countability? Performance Measurement in the New Zealand Public Service, 1992-2002. The Australian Journal of Public Administration, 66(4), 468484.

Maas, A. (1991). Congress and the Common Good. In K. Krehbiel, Information and Legislative Organization. Ann Arbor, MI: The University of Michigan Press.

MacDonald, J. A. (2010). Limitation Riders and Congressional Influence over Bureaucratic Policy Decisions. American Political Science Review, 104(4), 766-782.

MacNeil, N., \& Metz, H. W. (1956). The Hoover Report 1953-55: What It Means to You as a Citizen and Taxpayer. New York, NY: Macmillan.

Madison, J. (1788, February 20). The Federalist No. 58. Independent Journal. Retrieved May 19, 2012 from http://www.constitution.org/fed/federa58.htm.

March, J. G., \& Olsen, J. P. (1984). The New Institutionalism: Organizational Factors in Political Life. The American Political Science Review, 78(3), 734-749.

March, J. G., \& Olsen, J. P. (1989). Rediscovering Institutions: The Organizational Basis of Politics, New York, NY: The Free Press.

Maslin-Wicks, K. (1998). Two Types of Presidential Influence in Congress. Presidential Studies Quarterly, 28(1), 108-126.

Matthews, D. R. (1959). The Folkways of the United States Senate: Conformity to Group Norms and Legislative Effectiveness. The American Political Science Review, 53(4), 1064-1089.

Mayhew, D. R. (1974). Congress: The Electoral Connection, New Haven, CT: Yale University Press.

Mayhew, D. R. (1991). Divided We Govern: Party Control, Lawmaking, and Investigations, 1946-1990, New Haven: CT: Yale University Press.

McMurtry, V. A. (2010, June 18). Item Veto and Expanded Impoundment Proposals: History and Current Status. Congressional Research Service, RL33635.

McNab, R. M., \& Melese, F. (2003). Implementing the GPRA: Examining the Prospects for Performance Budgeting in the Federal Government. Public Budgeting \& Finance, 23(2), 73-95.

Mezey, M. L. (1991). Congress Within the U.S. Presidential System. In J. M. Thurber (Ed.), Divided Democracy: Cooperation and Conflict Between the President and Congress, Washington, DC: Congressional Quarterly Press.

Mills, G. B. (1984). Summary. In G. B. Mills \& J. L. Palmer (Eds.), Federal Budget Policy in the 1980s, Washington, DC: Urban Institute Press. 
Moe, R. C. (1978). Executive Branch Reorganization: An Overview, Washington, DC: Senate Committee on Governmental Affairs.

Moe, R. C. (2002). Reorganizing the Executive Branch in the $20^{\text {th }}$ Century: Landmark Commissions. Congressional Research Service, RL31446, Washington, DC: The Library of Congress.

Moe, T. (1985). The Politicized Presidency. In J. Chubb \& P. Peterson (Eds.), The New Direction in American Politics, Washington, DC: Brookings Institution.

Moe, T. M. (2006). Power and Political Institutions. In I. Shapiro, S. Skowronek, \& D. Galvin (Eds.), Rethinking Political Institutions: The Art of the State, New York, NY: New York University Press.

Morse Jr., E. H. (1971, July-August). Report of the President's Commission on Budget Concepts in Retrospect. Public Administration Review, 31(4), 443-450.

Mosher, F. (1969). Limitations and Problems of PPBS in the States. Public Administration Review, 29(2), 160-167.

Moynihan, D. P. (2005). Why and How Do State Governments Adopt and Implement Managing for Results. Journal of Public Administration Research and Theory, 15(2), 219-243.

Moynihan, D. P. (2006). What Do We Talk About When We Talk About Performance? Dialogue Theory and Performance Budgeting. Journal of Public Administration Research and Theory,16(2), 15168.

Mullen, P. R. (2006). Performance-Based Budgeting: The Contribution of the Program Assessment Rating Tool. Public Budgeting and Finance, 26(4), 79-88.

Nathan, R. P. (2005). Presidential Address: ‘Complexifying’ Performance Oversight in America's Governments. Journal of Policy Analysis and Management, 24(2), 207-15.

Neustadt, R. E. (1990). Presidential Power and the Modern Presidents: The Politics of Leadership from Roosevelt to Reagan, New York, NY: Free Press.

Neustadt, R. E. (1980). Presidential power: The politics of leadership from FDR to Carter. New York, NY: Macmillan.

Niskanen, W. (1971). Bureaucracy and Representative Government. Chicago: Aldine, Atherton.

Norcross, E., \& Adamson, J. (2007, July 17). An Analysis of the Office of Management and Budget's Program Assessment Rating Tool (PART) for Fiscal Year 2008. Mercatus Center, George Mason University, Arlington, VA. Retrieved February 12, 2008 from http://www.mercatus.org/ repository/docLib/20070725_Analysis_of_PART_for_FY_2008.pdf.

Norcross, E., \& McKenzie, K. (2006, May 30). An Analysis of the Office of Management and Budget's Program Assessment Rating Tool (PART) for Fiscal Year 2007. Mercatus Center, George Mason University, Arlington, VA. Retrieved August, 232009 from www.mercatus.org/ PublicationDetails .aspx?id=17770. 
Norman, R. (2004). Recovering from a Tidal Wave: New Directions for Performance Management in New Zealand's Public Sector. Public Finance and Management 4(3): 429-447.

Novick, D. (1968). The Origin and History of Program Budgeting. California Management Review, 11(1), 7-12.

Odiorne, G. S. (1965). Management by Objectives: a System of Managerial Leadership. In R. Rose, Managing Presidential Objectives, New York, NY: The Free Press.

Olson, M. (1965). The Logic of Collective Action: Public Goods and the Theory of Groups, Harvard University Press.

Olsen, R., \& Levy, D. (2004). Program Performance and the President's Budget: Do OMB's PART Scores Really Matter? Retrieved September 2, 2009 from www.mathematica-mpr.com/ publications/ PDFs/ OMBbudgeting.pdf.

Ornstein, N., \& Fortier, J. (2002). Relations with Congress. PS: Political Science \& Politics, 35(1), 47-50.

Osborne, D. (1993). Reinventing Government: Creating an Entrepreneurial Federal Establishment. In W. Marshall \& M. Schram (Eds.), Mandate for Change, Washington, DC: Progressive Policy Institute.

Osborne, D., \& Gaebler, T. (1992). Reinventing Government: How the Entrepreneurial Spirit is Transforming the Public Sector, Reading, MA: Addison-Wesley.

Ostrom Jr., C. W., \& Simon, D. M. (1985). Promise and Performance: A Dynamic Model of Presidential Popularity. American Political Science Review, 79(2), 334-358.

Patashnik, E. M. (1999). Ideas, Inheritances, and the Dynamics of Budgetary Change. Governance, 12(4), 147-174.

Penniman, H. (1952). American Parties and Elections, 5th ed., New York, NY: Appleton-Century-Crofts.

Peters, G., \& J. T. Woolley. (No Date). Ronald Reagan: Address Before a Joint Session of the Congress on the State of the Union, January 25, 1984, The American Presidency Project. Retrieved June 4, 2013 from http://www.presidency.ucsb.edu/ws/?pid=40205.

Pfiffner, J. P. (1991). Divided Government and the Problem of Governance. In J. M. Thurber (Ed.), Divided Democracy: Cooperation and Conflict Between the President and Congress, Washington, DC: Congressional Quarterly Press.

Pfeiffer, J. (2007). Performance Budgeting and Performance Management in the U.S. Government: Lessons from the PART Initiative, Presentation at a World Bank Brown-Bag Seminar, June 6, 2007, U.S. Office of Management and Budget.

Phyrr, P. A. (1977). The Zero-Base Approach to Government Budgeting. Public Administration Review, 37(1), 1-8.

Pinkett, H. T. (1965). The Keep Commission, 1905-1909: A Rooseveltian Effort for Administrative Reform. Journal of American History, 52(2): 297-312. 
Polenberg, R. (1966). Reorganizing Roosevelt's government: the controversy over Executive reorganization, 1936-1939, Cambridge, MA: Harvard University Press.

Posner, P. L. (2007). The Continuity of Change: Public Budgeting and Finance Reforms over 70 Years. Public Administration Review, 67(6), 1018-29.

Posner, P. P., \& Fantone, D. M. (2007). Assessing Federal Program Performance: Observations on the U.S. Office of Management and Budget's Program Assessment Rating Tool and Its Use in the Budget Process. Public Performance and Management Review, 30(3), 351-68.

President's Committee on Administrative Management. (1937). Administrative Management in the Government of the United States. Washington, DC: Government Printing Office.

Radin, B. (1998). The Government Performance and Results Act (GPRA): Hydra-Headed Monster or Flexible Management Tool? Public Administration Review, 58(4), 307-316.

Radin, B. (2000a). The Government Performance and Results Act and the Tradition of Federal Management Reform: Square Pegs in Round Holes. Journal of Public Administration Research and Theory, 10(1): 111-135.

Radin, B. A. (2000b). Intergovernmental Relationships and the Federal Performance Movement. Publius: The Journal of Federalism, 30(1), 143-158.

Radin, B. A. (2002). The Accountable Juggler: The Art of Leadership in a Federal Agency, Washington, DC: CQ Press.

Radin, B. A. (2005, June 14). Testimony Before the Senate Homeland Security and Government Affairs Subcommittee on Federal Financial Management, Government Information, and International Security. Retrieved July 18, 2006 from http://coburn.senate.gov/ffm/index.cfm?FuseAction= Files.View\& FileStore_id= fa26c105-ad63-4820-8eec-1ce855f8ef14.

Radin, B. A. (2006). Challenging the Performance Movement: Accountability, Complexity, and Democratic Values. Washington, DC: Georgetown University Press.

Reischauer, R. D. (1984). The Congressional Budget Process. In G. B. Mills \& J. L. Palmer (Eds.), Federal Budget Policy in the 1980s, Washington, DC: Urban Institute Press.

Rodgers, M., \& Sullivan, D. (2006, May 10). Reconsidering the President's Commission on Budget Concepts of 1967” Federal Budget Policy Seminar, Harvard Law School, Briefing Paper No. 30. Retrieved May 23, 2013 from http://www.law.harvard.edu/faculty/hjackson/President_ Commission_30.pdf.

Rose, R. (1976). Managing Presidential Objectives. New York, NY: The Free Press.

Rosenbloom, David H. 1983. Public Administration Theory and the Separation of Powers, Public Administration Review, 43(3): 219-227.

Rosenthal, A. (2004). Heavy Lifting: The Job of the American Legislature. Washington, DC: Congressional Quarterly Press. 
Rourke, J. T. (1977). Zero-Base Budgeting and the United States General Accounting Office. International Journal of Government Auditing, 4(4), 2-13.

Rourke, J. T. (1978). The GAO: An Evolving Role. Public Administration Review, 38(5), 453-457.

Rubin, I. S. (1990). Budget Theory and Budget Practice: How Good the Fit? Public Administration Review, 50(2), 179-89.

Rubin, I. S. (2006). The Politics of Public Budgeting: Getting and Spending, Borrowing and Balancing. $5^{\text {th }}$ Ed. Washington, DC: CQ Press.

Rubin, I. S. (2010). The Politics of Public Budgeting: Getting and Spending, Borrowing and Balancing. $6^{\text {th }}$ Ed. Washington, DC: CQ Press.

Salamon, L. M. (1981). The Question of Goals. In P. L. Szanton (Ed.), Federal Reorganization: What Have We Learned, Chatham, NJ: Chatham House.

Savage, C. (2006, April 30). Bush Challenges Hundreds of Laws. The Boston Globe. Retrieved October 27, 2009 from http://www.boston.com/news/nation/articles/2006/04/30/ bush_challenges_ hundreds_of_laws/.

Scherer, J. (1967, December). The Report of the President's Commission on Budget Concepts: A Review. Monthly Review, Federal Reserve Bank of New York, 231-238. Retrieved May 23, 2013 from http://www.newyorkfed.org/research/monthly_review/1967_pdf/12_3_67.pdf.

Schick, A. (1966). The Road to PPB: The Stages of Budget Reform. Public Administration Review, 26(4), 243-58.

Schick, A. (1969). Systems Politics and Systems Budgeting. Public Administration Review, 29(2), 13751.

Schick, A. (1973). A Death in the Bureaucracy: The Demise of Federal PPB. Public Administration Review, 33(2), 146-156.

Schick, A. (1978). The Road from ZBB. Public Administration Review, 38(2), 177-180.

Schick, A. (1980). Congress and Money: Budgeting, Spending and Taxing. Washington, DC: The Urban Institute.

Schick, A. (1996). The Spirit of Reform: Managing the New Zealand State Sector in a Time of Change, State Services Commission and The Treasury: Wellington, New Zealand.

Schick, A. (2000). The Federal Budget: Politics, Policy, Process. Washington, DC: The Brookings Institution.

Shepsle, K. A., \& Weingast, B. R. (1984). Legislative Politics and Budget Outcomes. In G. B. Mills \& J. L. Palmer (Eds.), Federal Budget Policy in the 1980s, Washington, DC: Urban Institute Press.

Shogan, C. J. (2006). The Contemporary Presidency: The Sixth Year Curse. Presidential Studies Quarterly, 36(1), 89-101. 
Seidman, H. (1980). Politics, Position and Power: The Dynamics of Federal Organization. $3^{\text {rd }}$ Ed. New York, NY: Oxford University Press.

Sheingate, A. D. (2003). Political Entrepreneurship, Institutional Change, and American Political Development. Studies in American Political Development, 17(2), 185-203.

Simon, H. (1945). Administrative Behavior: A Study of Decision-Making Processes in Administrative Organizations, New York: The Free Press.

Singer, P. (2005, February 12). Deciding Where The Ax Will Fall. National Journal, 37(7), 464-465.

Skowronek, S. (2008). Presidential Leadership in Political Time: Reprise and Reappraisal. Lawrence, KS: University Press of Kansas.

Sorauf, F. J. (1968). Party Politics in America, Boston, MA: Little, Brown.

Spitzer, R. J. (1998). The item veto dispute and the secular crisis of the Presidency, Presidential Studies Quarterly, 28(4), 799-805.

Stalebrink, O. J. (2009). National Performance Mandates and Intergovernmental Collaboration: An Examination of the Program Assessment Rating Tool (PART). The American Review of Public Administration, 39(6), 619-639.

Stalebrink, O. J. \& Frisco, V. (2011). PART in Retrospect: An Examination of Legislators’ Attitudes Toward PART. Public Budgeting \& Finance, 31(2), 1-21.

Steinmo, S. H. (1994). American Exceptionalism Reconsidered: Culture or Institutions? In L. C. Dodd \& C. Jillson (Eds.), The Dynamics of American Politics: Approaches and Interpretations, University of Colorado-Boulder: Westview Press.

Stubbing, R. A. (1984). The Defense Budget. In G. B. Mills \& J. L. Palmer (Eds.), Federal Budget Policy in the 1980s, Washington, DC: Urban Institute Press.

Sundquist, J. L. (1990). Needed: A Political Theory for the New Era of Coalition Government in the United States. In R. E. DiClerico (Ed.), Analyzing the Presidency, Guilford, CT: The Duskin Publishing Group.

Taft, W. H. (1913). Message of the President of the United States Submitting for the Consideration of the Congress a Budget. 62d Congress, 3d Session, Senate Doc. No 1113. Washington, DC: Government Printing Office.

Thomas, N. C. (1978). Presidential Accountability since Watergate. Presidential Studies Quarterly, 8(4), 417-434.

Thurber, J. A. (1991). Divided Democracy: Cooperation and Conflict Between the President and Congress. Washington, DC: Congressional Quarterly Press.

Thurber, J. A. (1997). Centralization, Devolution, and Turf Protection in the Congressional Budget Process. In L. C. Dodd \& B. I. Oppenheimer (Eds.), Congress Reconsidered, 6th ed. Washington, DC: Congressional Quarterly Press. 
Tomkin, S. L. (1985). Playing Politics in OMB: Civil Servants Join the Game. Presidential Studies Quarterly, 15(1), 158-170.

Tullock, G. (1965). The politics of bureaucracy, Washington, DC: Public Affairs Press.

Tyler, C., \& Willand, J. (1997). Public budgeting in America: A twentieth century retrospective. Journal of Public Budgeting, Accounting \& Financial Management, 9(2), 189-219.

U.S. Congressional Budget Office. (1993). Using Performance Measures in the Federal Budget Process, Washington, DC: The Congress of the United States.

U.S. Congressional Record. (1946, July 25). Daily Edition, House of Representatives, 92(8), 1001510114.

U.S. Congressional Record. (1949, February 10). Daily Edition, Senate, 95(1), 1097-1139.

U.S. Congressional Record. (1995, February 6). Daily Edition, House of Representatives, 141 (23), H1225.

U.S. Department of Defense/Office of the Secretary of Defense/Program Analysis \& Evaluation. (2004). DoD’s Planning, Programming and Budgeting System (PPBS): A Historical Perspective. 37th Annual DoD Cost Analysis Symposium. Retrieved June 11, 2013 from http://dodcas. deltaresources.com/DODCAS\%20Archives/37th\%20DODCAS\%20\%282004\%29/Training/ PPBS.pdf

U.S. Department of the Treasury. (2012). Debt Limit: Myth v. Fact. Retrieved April 11, 2012 from http://www.treasury.gov/initiatives/Documents/Debt\%20Limit\%20Myth\%20v\%20Fact\%20FINA L.pdf.

U.S. General Accounting Office. (1997). Performance Budgeting: Past Initiatives Offer Insights for GPRA Implementation . Washington, DC: U.S. Government Printing Office Report no. GAO/AIMD-97-46.

U.S. General Accounting Office. (2000). Reinventing Government: Status of NPR Recommendations at 10 Federal Agencies. Washington, DC: U.S. Government Printing Office Report no. GAO/GGC00-145.

U.S. General Accounting Office. (2004a). Performance Budgeting: OMB’s Program Assessment Rating Tool Presents Opportunities and Challenges for Budget and Performance Integration: Washington, DC: U.S. Government Printing Office Report no. GAO-04-439T.

U.S. General Accounting Office. (2004b). Performance Budgeting: Observation on the Use of OMB's Program Assessment Rating Tool for the Fiscal Year 2004. GAO-04-174. Washington, D.C.

U.S. Government Accountability Office. (2005). Performance Budgeting: PART Focuses Attention on Program Performance but More Can Be Done to Engage Congress. GAO-06-28.Washington, DC.

U.S. Government Accountability Office. (2007). 21st Century Challenges: How Performance Budgeting Can Help: Washington, DC: U.S. Government Printing Office Report no. GAO-07-1194T. 
U.S. Government Accountability Office. (2008). Government Performance: Lessons Learned for the Next Administration on Using Performance Information to Improve Results: Washington, DC: U.S. Government Printing Office Report no. GAO-08-1026T.

U.S. Government Accountability Office. (No date). About Congressional Reports. Retrieved August 5, 2013 from http://www.gpo.gov/help/about_congressional_reports.htm.

U.S. House of Representatives. (1919). National Budget System: Hearings before the Select Committee on the Budget of the House of Representatives on the Establishment of a National Budget System; 66th Congress, First Session.

U.S. House of Representatives. (1938, April 1). Congressional Record. 4564-1619.

U.S. House of Representatives. (1976, June 30, July 27, 28). Zero-Base Budget Legislation, Hearings before the Task Force on Budget Process of the Committee on the Budget, 94th Cong., 2d sess.

U.S. House of Representatives. (1979, December 11, 12). Budget Act Review, Hearings before the Task Force on Budget Process of the Committee on the Budget, $96^{\text {th }}$ Cong., $1^{\text {st }}$ sess., Rept. 96-22.

U.S. House of Representatives. (2002). Linking Program Funding to Performance Results, Joint Hearing before the Subcommittee on Government Efficiency, Financial Management and Intergovernmental Relations of the Committee on Government Reform and the Subcommittee on Legislative and Budget Process of the Committee on Rules, $107^{\text {th }}$ Cong., 2d sess., Serial No. 107228.

U.S. House of Representatives. (2004). Should We Part Ways with GPRA: A Look at Performance Budgeting and Program Review, 108th Cong., 2d. sess., Rept. 108-144.

U.S. House of Representatives. (2005a). Program Assessment and Results Act, 109th Cong., 1st sess., Rept. 109-26, 3.

U.S. House of Representatives. (2005b, July 20). Performance-Based Budgeting, 109th Cong., 1st sess., Rept. 109-10.

U.S. House of Representatives. (2005c, March 17). The Administration's Strengthening America's Communities Initiative and its Impact on Economic Development, 1st sess., Rept. 109-8.

U.S. House of Representatives. (2006a, February 16). The President's Fiscal Year 2007 Discretionary Budget Performance, 109th Cong., 2d sess., Rept. 109-15.

U.S. House of Representatives. (2006b). Committee on the Budget, Concurrent Resolution on the Budget — Fiscal Year 2007, 109th Cong., 2d sess., Rept. 109-402.

U.S. House of Representatives. (2006c, June 9). Committee on Appropriations, Departments of Transportation, Treasury, and Housing and Urban Development, the Judiciary, District of Columbia and Independent Agencies Appropriations Bill, 2007, 109th Cong., 2d sess., Rept. 109495.

U.S. House of Representatives. (2006d, June 20). Committee on Appropriations, Departments of Labor, Health and Human Services, and Education, and Related Agencies Appropriations Bill, 2007, 109th Cong., 2d sess., Rept. 109-515. 
U.S. House of Representatives. (2006e). Committee on Government Reform, Bringing Communities into the 21st Century: A Report on Improving the Community Development Block Grant Program, 109th Cong., 2d sess., Rept. 109-365.

U.S. Joint Committee on Government Organization. (1937). Reorganization of the Executive Departments. HRG-1937-GOJ-0001. Washington, DC: Government Printing Office.

U.S. Joint Economic Committee. (1970). The Planning-Programing-Budgeting System: Progress and Potentials, Hearings of the Subcommittee on Economy in Government, 90th Congress, 1st Session September 14, 19, 20 and 21. In H. S. Diamond, The Budget and Consumer Sovereignty. American Journal of Economics and Sociology, 29(2), 163-178.

U.S. Office of Management and Budget. (No Date a). About Us. Retrieved August 23, 2009 from http://www.whitehouse.gov/omb/expectmore/about.html.

U.S. Office of Management and Budget. (No Date b). What's New. Retrieved August 23, 2009 from http://www.whitehouse.gov/omb/expectmore/whatsnew.htm.

U.S. Office of Management and Budget. (2002). The President's Management Agenda. Retrieved April 23, 2011 from http://www.cfo.doe.gov/budget/03budget/content/appendix/mgmt.pdf.

U.S. Office of Management and Budget. (2003). Performance and Management Assessments, Budget of the U.S. Government Fiscal Year 2004. Washington, DC: U.S. Government Printing Office.

U.S. Office of Management and Budget. (2005a). Guidance for Completing the Program Rating Assessment Tool (PART). Retrieved February 23, 2008 from http://www.whitehouse.gov/omb/ part/fy2005/2005_guidance.pdf.

U.S. Office of Management and Budget. (2005b). Circular No. A-11, Preparation, Submission, and Execution of the Budget, Retrieved December 29, 2006 from http://www.whitehouse.gov/omb/ circulars/a11/current_year/ a_11_2005.pdf.

U.S. Office of Management and Budget. (2006). Program Assessment Rating Tool Guidance No. 200602. Retrieved January 3, 2012 from http://georgewbush-whitehouse.archives.gov/omb/ performance/ fy2006/2006_guidance_final.pdf.

U.S. Office of Management and Budget. (2009). Analytical Perspectives: Budget of the U.S. Government Fiscal Year 2010. Washington, DC: U.S. Government Printing Office.

U.S. Office of Management and Budget. (2011). Circular No. A-11, Part 6, Preparation and Submission of Strategic Plans, Annual Performance Plans, and Annual Performance Reports. Retrieved January 6, 2012 from http://www.whitehouse.gov/sites/default/files/omb/assets/a11_current_year/ s200.pdf.

U.S. Office of Management and Budget. (2011). Historical Tables. Table 1.1-Summary of Receipts, Outlays, and Surpluses or Deficits: 1789-2017, Retrieved March 11, 2012 from http://www.whitehouse.gov/omb/ budget/Historicals.

U.S. Senate. (1937). Investigation of Executive Agencies of the Government. $75^{\text {th }}$ Cong., $1^{\text {st }}$ sess., Report No. 1275. 
U.S. Senate. (1938). Government Organization, $75^{\text {th }}$ Cong., 3d sess., Rept. 1236, Part 2.

U.S. Senate. (1946). Legislative Reorganization Act of 1946, 79 ${ }^{\text {th }}$ Cong., 2d sess., Rept. 1400.

U.S. Senate. (1949). National Security Act Amendments of 1949, 81st Cong., 1st sess., HRG-1949-SAS0004.

U.S. Senate. (1956). Budget and Accounting, Hearings before the Subcommittee on Reorganization of the Committee on Government Operations, $84^{\text {th }}$ Cong., 2d sess., S. 3897, Part 2.

U.S. Senate. (1967, August 23). Planning-Programming-Budgeting, Part 1, Hearings before the Subcommittee on National Security and International Operations of the Committee on Government Operations, $90^{\text {th }}$ Cong., $1^{\text {st }}$ sess.

U.S. Senate. (1968, July 11). Planning-Programming-Budgeting, Part 4, Hearings before the Subcommittee on National Security and International Operations of the Committee on Government Operations, $90^{\text {th }}$ Cong., 2d sess.

U.S. Senate. (1969, December 10). Planning-Programming-Budgeting, Part 5, Hearings before the Subcommittee on National Security and International Operations of the Committee on Government Operations, $91^{\text {st }}$ Cong., $1^{\text {st }}$ sess.

U.S. Senate. (1976a, March 17, 18, 19, 24, 25, April 6, 7). Government Economy and Spending Reform Act of 1976, Hearings before the Subcommittee on Intergovernmental Relations of the Committee on Government Operations, $94^{\text {th }}$ Cong., $2 \mathrm{~d}$ sess.

U.S. Senate. (1976b, September 15). S. 2925 The Government Economy and Spending Reform Act of 1976, Committee on Rules and Administration, $94^{\text {th }}$ Cong., $2 d$ sess.

U.S. Senate. (1984, April 9). Line-Item Veto, Hearing Before the Subcommittee on the Constitution of the Committee on the Judiciary, $98^{\text {th }}$ Cong., 2d sess., S. Hrg. 98-1131.

U.S. Senate. (2002). Subcommittee on Science, Technology, and Space of the Committee on Commerce, Science, and Transportation, NASA Reauthorization, 107th Cong., 2d sess., S. Rept. 107-1075.

U.S. Senate. (2005a). An Assessment of Federal Funding for Private Research and Development, $109^{\text {th }}$ Cong., $1^{\text {st }}$ sess., S. Rept. 109-349.

U.S. Senate. (2005b). An Assessment of the President's Management Agenda, 109th Cong., 1st sess., S. Rept 109-159.

U.S. Senate. (2005c). Nominations of: Ben S. Bernanke and Brian D. Montgomery, 109th Cong., 1st sess., S. Rept. 109-404, 3.

U.S. Senate. (2005d). Accountability and Results in Federal Budgeting, 109th Cong., 1st sess., S. Rept 109-353.

U.S. Senate. (2006). Committee on Appropriations, Transportation, Treasury, Housing and Urban Development, the Judiciary, and Related Agencies Appropriations Bill, 2007, 109th Cong., 2d sess., S. Rept. 109-293. 
U.S. Senate. (2007, March 28). Financial Services and General Government Appropriations for Fiscal Year 2008. $110^{\text {th }}$ Cong., $1^{\text {st }}$ sess., S. Hrg. $110-285$.

U.S. Senate. (2009). Nomination Hearing of Peter R. Orszag to be Director, Office of Management and Budget. Committee on Homeland Security and Governmental Affairs.

Van Maanen, J. (1973). Observations on the Making of Policemen. Human Organization, 32(4), 407-418.

Waldo, D. (1948). The Administrative State: A Study of the Political Theory of American Public Administration. New York: Ronald Press.

Wargo, M. J. (1994). The Impact of the President's Reinvention Plan on Evaluation. American Journal of Evaluation, 15(1), 63-72.

Wawro, G. (2000). Legislative Entrepreneurship in the U.S. House of Representatives. Ann Arbor: University of Michigan Press.

Weber, G. A. (1919). Organized Efforts for the Improvement of Methods of Administration in the United States, No. 6 D, New York, NY: Appleton.

Wessel, D. (2012). Red Ink: Inside the High-Stakes Politics of the Federal Budget. New York, NY: Crown Business.

White House. (2007, November 13). Executive Order: Improving Government Program Performance. Retrieved November 23, 2008 from http://www.whitehouse.gov/news/releases/2007/11/ 20071113-9.html.

Wholey, J. S., \& Hatry, H. P. (1992). The Case for Performance Monitoring. Public Administration Review, 52(6), 604-610.

Wildavsky, A. B. (1961). Political Implications of Budgetary Reform. Public Administration Review, 21(4), 183-190.

Wildavsky, A.B. (1964). The Politics of the Budgetary Process. Boston: Little Brown.

Wildavsky, A. B. (1997). The New Politics of the Budgetary Process. New York, NY: Longman.

Wildavsky, A., \& Caiden, N. (2004). The New Politics of the Budgetary Process. New York, NY: Longman.

Willoughby, W. F. (1918). The Problem of a National Budget. Institute for Government Research. New York, NY: D. Appleton and Company.

Wilson, J. Q. (1990). Does the Separation of Powers Still Work. In R. E. DiClerico (Ed.), Analyzing the Presidency, Guilford, CT: The Duskin Publishing Group.

Wilson, W. (1887). The Study of Administration. Political Science Quarterly, 2(2), 197-222.

Witko, C., \& Friedman, S. (2008). Business Backgrounds and Congressional Behavior. Congress \& the Presidency, 35(1), 71-86. 